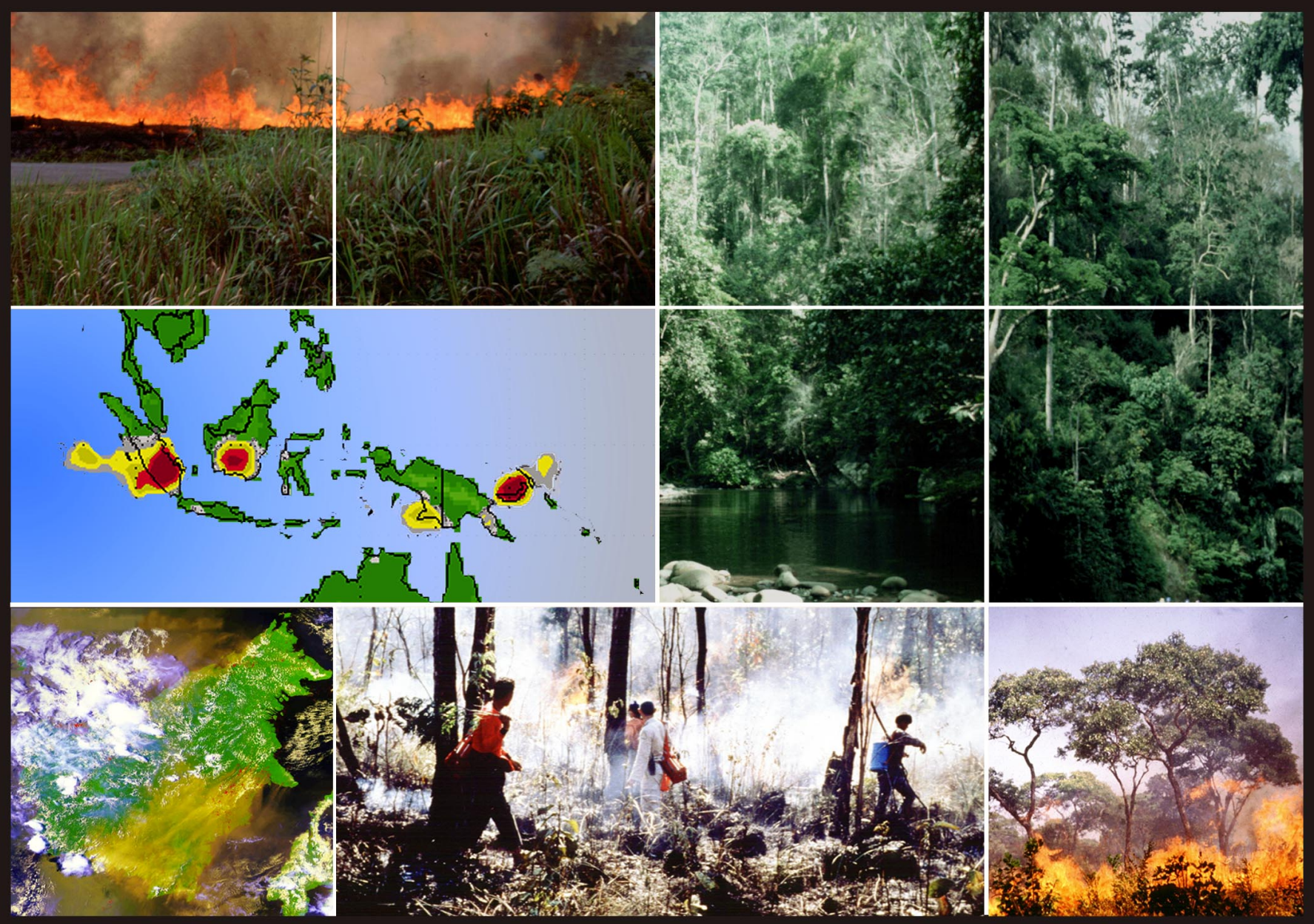

\title{
A Review of Fire Projects in Indonesia (1982-1998)
}

Rona Dennis 


\section{A Review of Fire Projects in Indonesia (1982-1998)}

Rona Dennis 
(C) 1999 Center for International Forestry Research (CIFOR)

Printed by SMT Grafika Desa Putera, Jakarta

\section{ISBN 979-8764-30-7}

(cover photos and images: Rona Dennis, Jeffrey Sayer, Timothy Boyle, P. Frost, NOAA-Meteorological Service Singapore Website and NASA-GSFC Website)

Center for International Forestry Research

Bogor, Indonesia

Mailing address: P.O. Box 6596 JKPWB, Jakarta 10065, Indonesia

Tel.: +62 (251) 622622; Fax: +62 (251) 622100

E-mail: cifor@cgiar.org

Website: http://www.cgiar.org/cifor 


\section{Table of Contents}

Acknowledgments $\quad$ xi

Executive Summary xiii

Introduction

Scope of this report 3

\section{Chapter 1. The Fires}

1.1 Fires prior to 1982

1.2 Fires in 1982-1983 5

1.3 Fires between 1983 and $1997 \quad 8$

1.4 Fires in $1997 \quad 11$

1.5 Fires in $1998 \quad 16$

\section{Chapter 2. Forest Fire Activities of}

Donor Countries prior to 1994

2.1 Fire Projects 19

2.2 Workshop and Seminars 21

2.3 Missions 21

2.4 Training Courses 23

\section{Chapter 3. Ongoing Fire Projects}

3.1 EU - Forest Fire Prevention and Control Project 25

3.2 GTZ - Integrated Forest Fire Management Project 27

3.3 JICA - Forest Fire Prevention and Management Project

3.4 Indonesia-UK Tropical Forest Management Programme

Chapter 4. Fire Projects in the Aftermath of the 1997 Fires

4.1 EU Fire Response Group

4.2 World Wide Fund For Nature-Indonesia Analysis of the Causes and Impacts of Forest Fires and Haze

4.3 ADB - Regional Technical Assistance on Strengthening ASEAN's Capacity to Prevent and Mitigate Transboundary Pollution 
4.4 Advisory Technical Assistance Planning for Mitigation of Drought and Fire Damage - ADB

4.5 Environmental Emergency Project - UNDP/State Ministry of Environment

4.6 ITTO - National Guidelines on the Protection of Forest Against Fire

4.7 United States Government

4.7.1 USAID's Assessment of the Land and Forest

Fire Situation: Interpretation of Satellite Imagery

4.7.2 East Asia and Pacific Environmental Initiative

4.8 Centre for Remote Imaging, Sensing and Processing, Singapore

4.9 South East Asian Fire Experiment

4.10 Monitoring Tropical Vegetation Unit of the EC

4.11 Impacts Centre for Southeast Asia - Land Use Planning and Management to Reduce the Impacts of Transboundary Pollution from Fires in Southeast Asia

\section{Chapter 5. Proposed Fire Projects}

5.1 CIFOR, ICRAF and UNESCO - The Underlying Causes and Impacts of Fires in Southeast Asia

5.2 IUCN and WWF - Project 'Firefight' to Establish a Collaborative Global Network for Forest Fire Prevention and Control

5.3 ACIAR - Fire Management Systems for Sustainable Agricultural and Forestry Development in Eastern Indonesia, Review Workshop

\section{Chapter 6. Indonesia's Response to the Fires and} Smoke Haze

6.1 National Coordination Team for Land and Forest

Fire Control

6.2 Ministry of Agriculture

6.3 Ministry of Forestry

6.4 Ministry of Health

6.5 Others

6.6 NGO Relief Efforts 


\section{Chapter 7. International Relief Assistance}

7.1 UN OCHA in 1997

7.2 UN OCHA/UNEP in 1998

7.3 Other UN Agencies $\quad 57$

7.4 Donor Countries $\quad 57$

\section{Chapter 8. Summary of Fire Projects}

8.1 Temporal Trends in Fire Projects 61

8.2 General Trends in Fire Project Objectives 62

8.3 A comparison of the Long-Term Fire Projects 64

8.4 A comparison of the New Generation of Fire Projects 67

8.5 Is overlap a bad thing? $\quad 67$

8.6 Conclusion 68

\section{Appendices:}

Appendix 1. The use of NOAA-AVHRR Fire Monitoring Systems

Appendix 2. A selection of useful web sites relating to the fires and smoke over Indonesia

Appendix 3. Examples of Maps and Images of the 1997-98 Fires and Smoke

Appendix 4. Reference List from Meijaard and Dennis (1997) Forest Fire Bibliography

References Cited

\section{List of Boxes}

Box 1. What is the El Niño-Southern Oscillation? 2

Box 2. The contribution of burning coal seams 6

Box 3. Economic value of timber losses in 1982-83 8

Box 4. Bukit Soeharto 8

\section{List of Tables}

Table 1. Burnt area estimates for 1994

Table 2. Estimates of forest and non-forest land burnt in 1997

Table 3. Relative proportion of areas and numbers of hot spots for different land classes in Southern Sumatra from EUFREG

Table 4. Timber and plantation companies warned for burning land

Table 5a. Fire-related damages (US\$ Millions)

Table 5b. Haze-related damages (US\$ millions)

Table 6. Economic Losses due to 1997/1998 drought and fires (ADB 1999) 
Table 7. Summary of Fire Projects 63

Table 8. Ongoing and new fire projects and their main objectives 65

\section{List of Figures}

Figure 1. The SOI (6 month average) April-Sept for the years 1876-1997

Figure 2. SOI for 1982-83 and 1997-98 compared 12

Figure 3. Temporal pattern of fire projects between 1982 and $1998 \quad 62$

\section{List of Maps}

Map 1. Location of Indonesia and its neighbours, also showing established fire projects

Map 2. Example of fire hot spot from IFFM web site 71

Map 3. Example of fire hot spot from the JICA fire project 71

Map 4. Example of fire hot spot from the JICA fire project 72

Map 5. Example of fire hot spot from the BAPEDAL web site 73

Map 6. Example of fire hot spot from Meteorological Service Singapore web site

Map 7. Example of NOAA AVHRR image with fire hot spots from Meteorogical Service Singapore web site

Map 8. Fire and smoke haze near Banjarmasin, South Kalimantan

Map 9. Example of processed NOAA AVHRR image of Southern Coast of Kalimantan, dated 8 October 1997, from NOAA web site

Map 10a. Example of fire map for Central Kalimantan Coastal area, October 1997, from the USDA Forest Service web site

Map 10b. Example of fire for East Kalimantan, February 1998, from USDA Forest Service web site

Map 11. Example of TOM Smoke image over Indonesia during the 1997 fires

Map 12a. ASEAN Fire Weather Map - Precipitation 6 July 1998

Map 12b. ASEAN Fire Weather Map - Fire Weather Index 6 July 1998 


\title{
Glossary
}

\author{
ABRI \\ ADTA \\ ADB \\ ASEAN \\ AVHRR \\ BAKORNAS \\ BAPEDAL \\ BAPPEDA \\ BAPPENAS \\ BIPHUT \\ BMG \\ BPPT \\ Bupati \\ Camat \\ CIFOR \\ CRISP \\ DFID \\ Dinas Kehutanan \\ EC \\ EEPSEA \\ ENSO \\ ERS \\ ESA \\ EU \\ EUFREG \\ EWS \\ FAO \\ FFPCP \\ FFPMP \\ GIS \\ GOI \\ GPS \\ GTZ \\ HIMAWARI \\ Angkatan Bersenjata Republik Indonesia (Indonesian Armed Forces) \\ Advisory Technical Assistance (ADB) \\ Asian Development Bank \\ Association of South East Asian Nations \\ Advanced Very High Resolution Radiometer \\ Badan Koordinasi Nasional (Coordinating Agency for National Emergencies) \\ Badan Pengendalian Dampak Lingkungan (Environmental Impact Management Agency) \\ Badan Perencanaan Pembangunan Daerah (Regional Development Planning Board) \\ Badan Perencanaan Pembangunan Nasional (National Development Planning Board) \\ Balai Inventarisasi dan Pemetaan Hutan (Forest Inventory and Mapping Office - provincial \\ level equivalent of INTAG) \\ Badan Meteorologi dan Geofisika (Agency for Meterology and Geophysics) \\ Badan Pengkajian dan Penerapan Teknologi (Agency for the Assessment and Application \\ of Technology) \\ Regent, officer in charge of Regency (Kabupaten) \\ District head (kecamatan - district) \\ Center for International Forestry Research \\ Centre for Remote Imaging, Sensing, and Processing \\ Department for International Development (formerly ODA) \\ Provincial Forest Service (reports to provincial governor) \\ European Commission \\ Economy and Environment Programme for South East Asia \\ El Niño-Southern Oscillation \\ European Radar Satellite \\ European Space Agency \\ European Union \\ EU Fire Response Group \\ Early Warning System \\ Food and Agriculture Organisation of the United Nations \\ Forest Fire Prevention and Control Programme (EU Fire Project) \\ Forest Fire Prevention and Management Project (JICA Fire Project) \\ Geographic Information System \\ Government of the Republic of Indonesia \\ Global Positioning System \\ Deutsche Gesellschaft für Technische Zusammenarbeit (German Technical Cooperation) \\ Japanese meteorological satellite
}




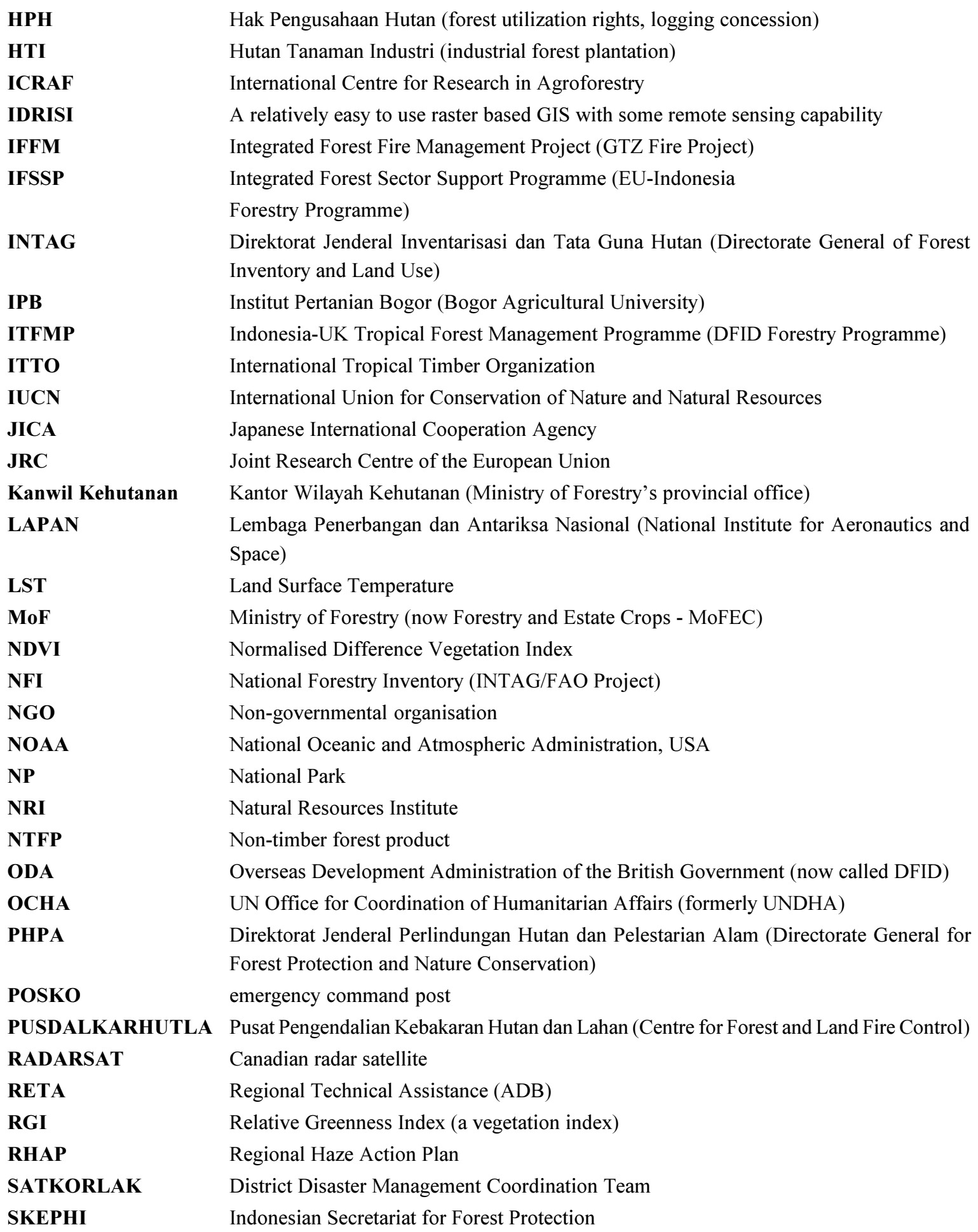


SPOT

SOI

TA

TKNPKLH

TOMS

UNDAC

UNDHA

UNDP

UNEP

UNEP-GRID

UNESCO

USAID

USFS

WALHI

WHO

WRI

WWF

WWF-ID
Satellite Probatoire pour l'Observation de la Terre (French-Swedish satellite imaging system)

Southern Oscillation Index

Technical Assistance

Tim Koordinasi Nasional Pengendalian Kebakaran Lahan dan Hutan (National Coordination Team for Land and Forest Fire Control)

Total Ozone Mapping Satellite

UN Disaster Assessment and Coordination

UN Department of Humanitarian Affairs

UN Development Programme

UN Environment Programme

UNEP Global Resource Information Database

UN Educational, Scientific and Cultural Organization

US Agency for International Development

US Forest Service

Indonesian Environmental Forum

World Health Organization

World Resources Institute

World Wide Fund for Nature

World Wide Fund for Nature-Indonesia 


\section{The Author}

Rona Dennis is a remote sensing and GIS analyst based at the Center for International Forestry Research (CIFOR), Bogor, Indonesia. Her main topics are assessing forest cover and forest use changes using remote sensing and GIS, participatory mapping techniques and the causes and impacts of fire on land cover and use over time. She holds a BSc in Geography and an MSc in Environmental Remote Sensing from the University of Aberdeen in the United Kingdom. After graduating she worked for 4 years as an international consultant in countries such as Spain, Pakistan, and China. Following this she spent 6 years in Indonesia implementing the mapping, remote sensing and GIS component of a donor-assisted community-based conservation project in the Ministry of Forestry. 


\section{Acknowledgements}

A large number of people made this report possible. The author would like to thank in particular the following people: William Sunderlin of CIFOR, who read the report in great detail and made numerous constructive comments and edits, and Erik Meijaard of Ecosense Consultants, with whom the author had many valuable discussions regarding the structure of the report. Thanks also are due to the following people for valuable comments on the content and structure of earlier drafts of the report: Neil Byron, Reidar Persson, and Jeff Sayer of CIFOR; Fred Stolle of ICRAF; and Jim Schweithelm of WWF.

The author would also like to acknowledge and thank the following people for providing information used in this report: Pak Effendy Sumardja and Prof. Dr Kasumbogo Untung of the State Ministry of the Environment; Dennis Dykstra, Daju Pradnja Resosudarmo, and Carol Colfer of CIFOR; Tom Tomich of ICRAF; Mary Melnyk of USAID; David Wall, formerly of the EU-IFSSP; John Keating and Jozsef Micski of the EU-Forest Liaison Bureau; Chris Legg and Yves Laumonier of the EU-FIMP; Pietro Ceccato of NRI and EUFREG; Eric Wakker of AIDEnvironment; Martin Hardiono and Fernando Gonzalez of WWF Indonesia; Doug Fuller of George Washington University; Nyoman Suryadiputra of Wetlands International; Ludwig Schindler and Anja Hoffmann of the GTZ IFFM Project and Christian Gönner of the GTZ Sustainable Forestry Management Project (SFMP); Ueda Tomoyuki of the JICA FFPMP; Roderick Bowen of the EU FFPCP; Dami Buchori of IPB and UNDP; Hira Jhamtani of the UNDP Fire Project; Ellen Steenburgh of KLH; Peter King of ADB; Eric Scarsborough of the ADB-RETA; Rencana Tarigan of the EU- Leuser Development Programme; Liew Soo Chin of CRISP; and Nick Jewell of the ITFMP. 


\section{Executive Summary}

This report was written in response to a clear need by the national and international aid, development and research community, including the CIFORICRAF-UNESCO consortium for information on past, present and proposed fire projects. By compiling this information into one report it is easier to focus on specific trends in addressing the fire problem and to identify possible gaps in our knowledge regarding causes and effects of fires over the past two decades.

Fire in the wet tropical climate of Indonesia is not a new phenomenon. Evidence of burning dates back to 17000 years before present. Evidence of smoke and haze can be found in historical records from the nineteenth century. The occurrence of extreme fire events is linked with the ENSO (El Niño-Southern Oscillation) climate phenomenon that produces an extended long dry period, especially over Indonesia.

The 'Great Fire of Borneo' in 1982-83 was one of the worst fire events in recent decades. An estimated 3.2 million hectares of land (mainly logged-over forest) burned in East Kalimantan; primary forest suffered little by comparison and recovered quickly. Small holders clearing land for cultivation were primarily blamed for starting fires that rapidly spread out of control. Subsequent fire events linked to ENSO occurred in 1987, 1991 1994 and most recently in 1997-98. Blame for these fires has been variously attributed to shifting cultivation, near-ground coal seams, and land clearing by smallholders and largeholders. The impact of the latest fire event is immense; estimates of the area burnt in 1997 vary between 2 and 5 million hectares (forest and non-forest), the number of people affected by smoke haze and fire at 75 million, and the total economic costs in the region at as much as US\$ 4.5 billion.
The 1982-83 fires brought the issue to world attention. Between 1982 and 1992 short- to medium-term assistance in addressing the problem was given as fact finding missions, emergency assistance, technical aid and equipment and training courses, as well as management support from several agencies and countries such as EC, FAO, JICA, UN, ITTO, GTZ, USA and Australia.

After 1992 three long-term projects were initiated with the objectives of management and monitoring of fires. These were the EU-Forest Fire Prevention and Control Project (FFPCP) in Southern Sumatra (1995-1998), GTZ's Integrated Forest Fire Management Project (IFFM) in East Kalimantan (1994-2000), and JICA's Forest Fire Prevention and Management Project (FFPMP) in Bogor, Jambi and West Kalimantan (1996-2001). In addition, the Indonesia-UK Tropical Forest Management Programme (ITFMP) started in 1992 and comprised a number of components related to fires as part of its overall improved forest management objective. All four projects have locally installed NOAA-AVHRR satellite image receiving systems in order to detect and monitor fire hot spot activity. In addition to strengthening the institutional capacity of the Ministry of Forestry to deal with fires, FFPCP, IFFM and FFPMP have also adopted a rural or community-based approach to fire prevention and control.

After the 1997 fire event numerous short- and long-term fire projects were proposed and started. Short-term projects, such as that carried out by EUFREG (October 1997-May 1998), were mainly aimed at providing timely estimates of total area burnt. Others, such as the first phase of the WWF project (October 1997-September 1998) and the ADB's regional (RETA) (April 1997-April 1998) and national (ADTA) (July 1998-January 1999) 
projects, within a short time frame try to cover many aspects of fire problem such as socio-economic assessments, fire-fighting, area estimates, economic and policy assessments and ecological assessments. Representing a longer-term approach from the outset (October 1998-October 2001), CIFORICRAF-UNESCO propose an in-depth study of the underlying causes and effects of fires.

In addition to the international response Indonesia has several government agencies charged with the task of preventing, monitoring and controlling land and forest fires. Following the forest and land fires of 1994, the National Coordination Team for Land and Forest Fire Control (TKNPKHL) was established in 1995. The team is headed by the State Minister for Environment and the Director General of Forest Protection and Nature Conservation (PHPA). Members of the team include senior officials from the Ministries of Home Affairs, Mining and Energy, Agriculture, Transmigration, Social Affairs, LAPAN, BAPPENAS and BPPT. The Deputy Head of the team and the secretariat are located at BAPEDAL. During the 1997 event BAPEDAL, as the secretariat of TKNPKH, founded a POSKO (emergency command post) to coordinate control and monitoring efforts. Several ministries took action themselves by revoking logging licences or setting deadlines to plantation companies to prove their non-involvement in fires on their land.

From all the projects and relief operations several important conclusions can be drawn. There is a clear temporal trend in the projects. Interest in fire is only short-lived after a major fire event. Before the 1994 fire event little attention was paid to the fire problem and missions mainly focussed on control and prevention of fires. It was only after 1994 that there was a shift of interest to understanding the causes and impacts of the fires in addition to practical fire prevention and control. Most of the new generation of fire projects established in 1997-98 address both issues. The two new longer-term projects of CIFOR-ICRAFUNESCO and WWF have similar objectives and balance activities between technical, social and policy objectives to mitigate and understand fires in Indonesia. 


\section{Introduction}

In the past two years, Indonesia has experienced more media coverage and world attention than at any time in the last 30 years. It started with the forest and land fires in 1997, and was followed by the economic crisis and, by the resignation of President Soeharto. Indonesia was not alone in experiencing devastating fires during 1997 and 1998. Australia, Brazil, Brunei, Malaysia, the Philippines and, more recently, Mexico and the state of Florida in the United States have felt the effects of abnormal droughts induced by the El Niño-Southern Oscillation (ENSO) climatic phenomenon (refer to Box 1).

Fires occur in Indonesia (and Southeast Asia) annually as largeholders and smallholders alike clear land for cultivation. During pronounced ENSO years, when conditions are unusually dry, fires and smoke tend to have a much more serious and far-reaching effect. During the past two decades, serious fires have occurred in 1982-83, 1987, 1991 and 1994.

Indonesia experienced an exceptional year in 1997. Between August and November extensive fires ravaged large areas of Indonesia, particularly the islands of Sumatra and Kalimantan. These forest and land fires, and the accompanying smoke, caused serious air pollution, damage to public health, loss of life, destruction of property, and substantial economic losses in many parts of Southeast Asia. The burnt area has been estimated at between 2 and 5 million ha (forest and nonforest), the number of people affected by smoke haze and fire is 75 million, and the total economic cost to the region is as much as US\$ 4.5 billion (EEPSEA and WWF 1998a).

Just as Indonesia was recovering from the 1997 fires, the drought prevailing in East Kalimantan provided ideal conditions for a new spate of fires, which lasted from January until May 1998. Little could be done to extinguish these fires, and Kalimantan experienced thick smoke haze for a second time in less than a year. Official estimates put the burnt area at more than 550000 ha, with timber revenue losses at US\$ 1 billion (The Jakarta Post, 27/4/98). Estimates from other sources place the burnt area at closer to 4 million ha (Siegert and Hoffmann 1998). A study of the economic losses for 1997/1998 due to fire and drought puts the figure between US\$ 8.5 and 9.4 billion (ADB, 1999).

The fires of 1982-83, 1987, 1991 and 1994 fuelled the interest and commitment of donors in helping Indonesia deal with the problem. After many missions, what remains today are three longterm fire projects implemented by EU, GTZ and JICA. In response to the national and international disaster of 1997, many countries pledged emergency assistance in fire suppression and social relief measures. During that year, several missions visited Indonesia and, in response, a number of postfire studies were proposed by the Asian Development Bank, UN Development Programme and the World Wide Fund for Nature, among others. The scope of many of these projects is wide and the time frame is relatively short (up to 12 months). On a longer time frame, a joint proposal by CIFOR, ICRAF and UNESCO aims to carry out a 3-year research project addressing the underlying causes and impacts of land and forest fires in Indonesia; it would assess both the historic and current conditions.

The reemergence of devastating fires in 1998 attracted further interest, particularly from the UN Environment Programme (UNEP), which is keen to encourage longer-term assistance in addressing the forest fire problem. 


\section{Box 1. What is the El Niño-Southern Oscillation?}

The El Niño-Southern Oscillation is the result of a cyclic warming and cooling of the surface of the eastern Pacific. This region of the ocean is normally cooler than its equatorial location would suggest, mainly because of the influence of northeasterly trade winds, a cold ocean current flowing up the coast of Chile, and the upwelling of cold deep water off Peru.

At times, the influence of these cold waters wane causing the surface of the eastern and central Pacific to warm up; this is called an El Niño event. ENSOs also affect trade wind patterns, which in turn influence sea surface temperatures over vast areas of the Pacific. These changes can produce extreme weather throughout the tropics and have been linked to severe droughts in Indonesia and Australia, and heavy rainfall in South America.

At other times, the injection of cold water becomes more intense than usual, causing the surface of the eastern Pacific to cool; this is called a La Niña event. This results in heavy rainfall in Australia and Indonesia, and droughts in South America. An El Niño event is usually followed by a La Niña event (Source: http:// www.vision.net.au/-daly/elnino.htm).

There have been 20 ENSOs in the 120 years since 1877. There is now much debate surrounding the idea that the frequency and intensity of ENSOs is increasing, and there is some evidence that this has been the trend in the past 20 years (Trenberth and Hoar 1997).

Figure 1. Southern Oscillation Index* (SOI) (6 month average, April-Sept, for the years 1876-1997)

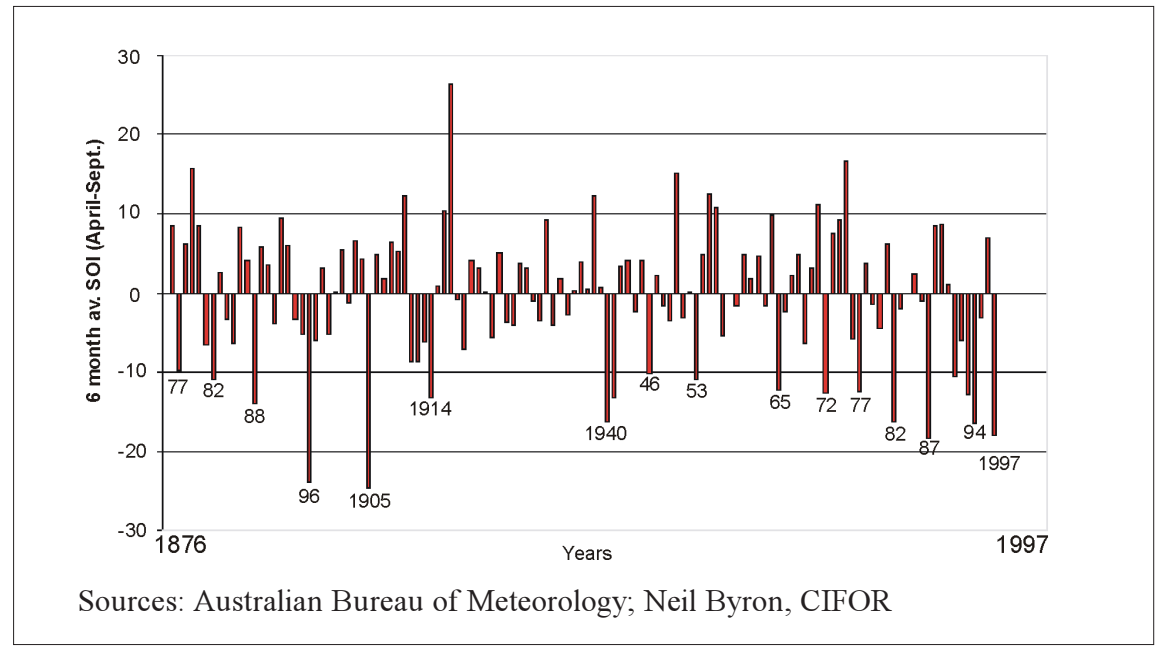

${ }^{*}$ Normalised difference in surface pressure between Tahiti, French Polynesia and Darwin is a measure of the strength of trade winds, which have a component of flow from regions of high to low pressure. High SOI (large pressure difference) is associated with stronger than normal trade winds and La Niña conditions, and low SOI (smaller pressure difference) is associated with weaker than normal trade winds and El Niño conditions. (Definition from http://www.pmel.noaa.gov/toga-tao/ensodefs.html 


\section{Scope of this report}

In the process of developing the CIFOR/ICRAF/ UNESCO fire research proposal, we consulted literature on past, current and proposed fire projects, and visited representatives of other projects. We did this in an effort to identify the most useful course of action and to avoid duplication of effort. A large amount of information was collected about fire projects in Indonesia. This report compiles most of this information into chapters describing past, present and proposed fire projects. The first chapter sets the scene by providing a brief history of major forest fires in Indonesia. The subsequent chapters describe various projects. A basic synthesis of these fire projects is presented in the final chapter.

As a reference for the reader, Map 1 provides a location map of Indonesia showing the provinces of Sumatra and Kalimantan.

Map 1. Location of Indonesia and its neighbours, also showing location of established fire projects

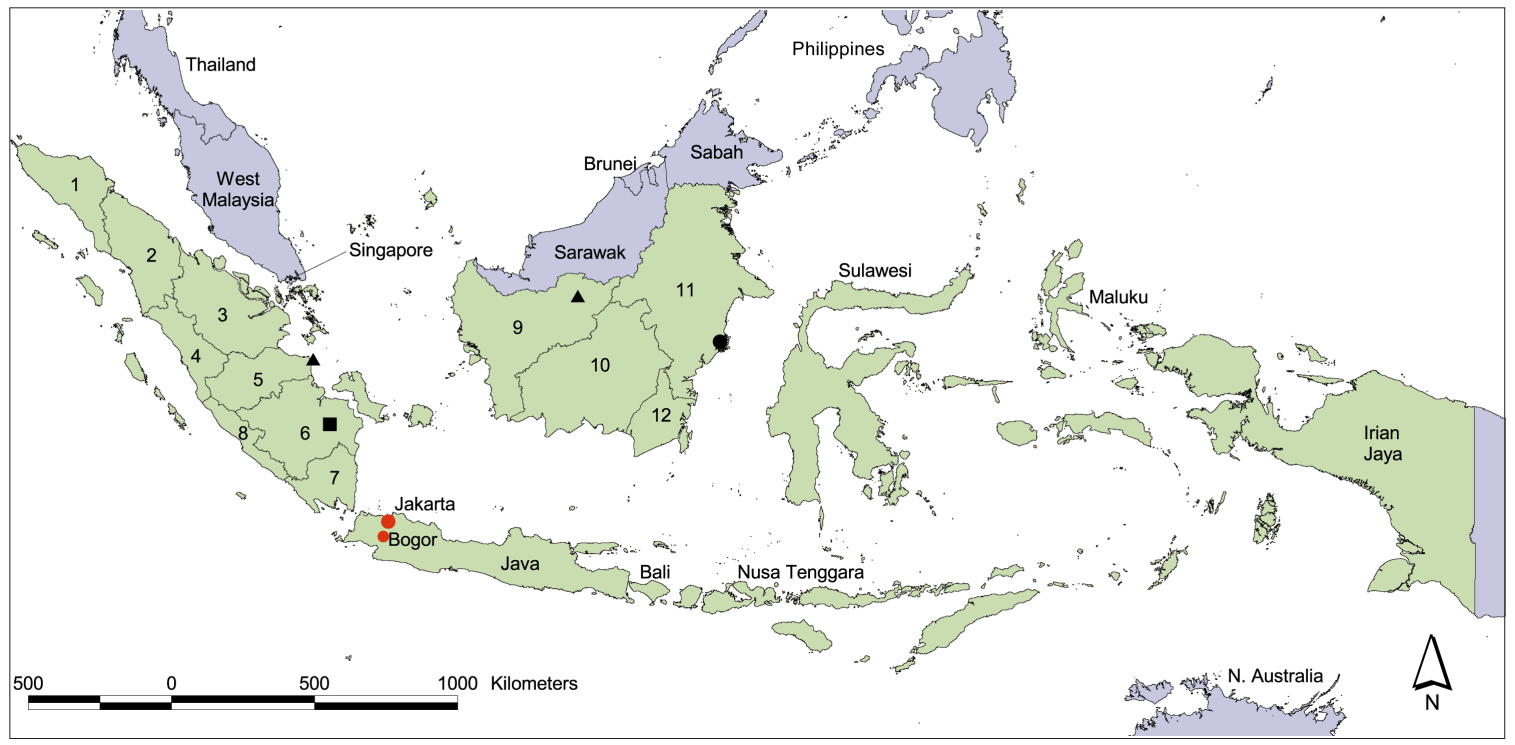

\section{Legend:}

Green - Indonesia

Provinces of Sumatra

5. Jambi
6. South Sumatra
7. Lampung
8. Bengkulu

Provinces of Kalimantan

Location of established fire projects

1. Aceh

9. West Kalimantan

10. Central Kalimantan

2. North Sumatra

7. Lampung

11. East Kalimantan

- GTZ IFFM Project - Samarinda

Riau

8. Bengkulu

12. South Kalimantan

- JICA FFPMP - Berbak, Jambi and Nanga Pinoh, W. Kalimantan 


\section{The Fires}

\subsection{Fires prior to 1982}

Forest and land fires are not a recent phenomenon in Indonesia. Explorers to Borneo dating back to the fifteenth century reported forest fires, and such reports continued to the twentieth century. The prehistory and history of fire in Southeast Asian vegetation types is closely linked with the effects of climate variability and human influences. Evidence of ancient fires in East Kalimantan was found in the late 1980s (Goldammer and Siebert 1990) from radiocarbon dating of charcoal in soils. The results showed that forest fires occurred in that area between ca. 17510 and ca. 350 years before present.

The log books of Portuguese and Dutch explorers in Southeast Asia in the fifteenth and sixteenth centuries reported huge fires in peat swamps in southern Borneo, and a choking haze that extended as far as present-day Singapore. Careful historical analysis and cross-referencing show that this occurred only in particular years that we now know were ENSO years (Potter 1997; Brookfield et al. 1995).

Throughout the nineteenth century, Singaporean newspapers reported smoke and haze problems in every ENSO year (Byron and Shepherd 1998). In 1877, Bock (1881) reported a very serious drought along the coasts of Borneo and Sulawesi. The forests were reportedly dry and leafless, and there was a shortage of food and drinking water. The drought lasted for nine months, but there was no report of fire. Michielsen (1882), who visited what is now Central Kalimantan in 1880 , also found evidence of the 1877 drought. He remarked on many locations seriously affected by large forest fires: 'It is hard to identify how the fire has spread through the forest. Although we had continued our way after leaving the peat swamp forest ... , we alternately passed dense forest, apparently unaffected by the fires, and completely burned patches, which even now [three years later], only showed sparse regrowth of shrub'.

For West Kalimantan, Giesen (1996) notes that reports of forest fires in the Danau Sentarum Wildlife Reserve date back to the last century. Pfeiffer (1856) observed extensive areas of burnt stumps, while Gerlach (1881) reported extensive fires in the forests in the northwestern part of the current reserve. Other descriptions of fires in this area came from Molengraaff (1900). In contrast to these sources, Polak (1949) and Vaas (1952) reported the apparent absence of fires in Danau Sentarum, and the latter suggested that this was the result of the lack of fishing activity during the Second World War.

\subsection{Fires in 1982-1983}

\section{The 1982-83 fires in East Kalimantan}

From July 1982 to April 1983, an exceptional drought struck East Kalimantan. This coincided with a particularly marked ENSO. This negative SOI can be seen in Figure 1. Very small amounts of rain fell in July and August, and rainfall was below average between September and December. The fires started in November-December 1982. At this time the vegetation was still comparatively moist and the trees had not yet shed their leaves and the fire did not cause much damage as it crept slowly along the forest floor. However, the worst was still to come. Between January and April (1983) it was so dry that, for the total 10-month period going back to July 1982, there was a $68 \%$ precipitation deficit in comparison with the long- 
term average (Lennertz and Panzer 1983). When the rains eventually fell in early May 1983, the fires were checked and the skies cleared.

As a consequence of the 1982-83 drought, agricultural production in the affected part of East Kalimantan virtually ceased; fresh vegetables became scarce, and many fruit trees and root crops died as the drought continued. Shortages of food and seed grain occurred in some regions. Falling water levels in major rivers caused problems for navigation.

In peat and freshwater swamp areas, the organic matter dried up to a depth exceeding $0.5 \mathrm{~m}$ (Lennertz and Panzer 1983). In the forest, dry leaves accumulated on the ground and the top layer of organic material dried out, while tree crops and wood residue provided additional tinder in loggedover areas, thus contributing to a high fire risk.

When farmers and settlers started to clear vegetation by burning in preparation for the next planting cycle, fires quickly spread out of control and large tracts of logged-over timber stands, primary forest, peat swamps and swamp forests were set alight (Lennertz and Panzer 1983). Peat and surface burning coal seams (see Box 2) gave

\section{Box 2. The contribution of burning coal seams}

East Kalimantan is well known for its coal deposits; it is also known for some of its long lasting coal seam fires, which have contributed to some of the forest fires in that province (Bird 1995). Many people assume that the approximately 150 coal seams now burning were ignited by the 1982-83 wildfires. However, Goldammer and Siebert (1990) question this, as they found numerous oral reports of burning coal seams before 1982-83. Bock (1881) recounted that local people consider coal seams to have been burning 'since the memory of man'. Goldammer and Siebert (1990) dated these ancient coal seams by investigating the baking effect of subsurface fires on upper soil layers. Analysis of burnt clay, collected on top of an extinguished coal seam in the vicinity of active coal fires, proved a fire event 15000 to 13200 years before present. off acrid smoke from February to April 1983. This smoke caused health problems and obscured the sky, disrupting air services in and out of Balikpapan. So severe was the situation that smoke from the fires was reported as far away as Java and Brunei (Lennertz and Panzer 1983).

Organised efforts to control the fires were practically non-existent. Lennertz and Panzer (1983) state that 'it was not only the lack of equipment and experience that prevented active fire fighting but also the conviction of some people that fire was beneficial in clearing land and future crop production'.

It was after these fires that the Ministry of Forestry released a "prevention is best" plan. Following this in 1983, a special fire mitigation task force was established within the Ministry.

\section{Burnt area estimates}

Estimates of the land area affected by the 1982-83 fires were not promptly available. At the time, reporting procedures and technology were not in place to provide such information. Initial estimates by Lennertz and Panzer (1983) were 3.5 million ha of totally and partially burnt land. This included 800000 ha of primary forest; 1400000 ha of logged-over forest; 750,000 ha of secondary forest, shifting cultivation and settlements; and 550000 ha of peat swamp forest.

The results of a longer and more thorough study by GTZ in 1988-89 (Schindele et al. 1989) concluded that 3.2 million ha burned to varying degrees, of which 2.7 million ha were classified as forest. Schindele et al. (1989) mapped a total area of 4733000 ha, of which 410000 ha were classified as undisturbed primary forest. They found that only 45000 ha $(11 \%)$ of the total primary forest area were affected by fire. Most of the fire damage in the primary forest was only at ground level; little damage was found at higher levels. The team stated that 'full recovery of the forest could be expected within a few years'. By 1988, when the vegetation classification was carried out, it was reported that no indication of fire disturbance remained. 
Schindele et al. (1989) mapped 1096000 ha of lightly disturbed forest and found that $58 \%$ was burnt. They found that the remaining $42 \%$ was disturbed by drought or logging activities between 1982 and 1988; of these lightly disturbed forests, $75 \%$ had been logged before the 1982-83 fire and $25 \%$ was primary forest. In these forests fire had mainly affected the lower and middle storeys. The authors remarked that the potential for quick recovery was good, but that rehabilitation measures should be applied.

Moderately disturbed forest accounted for 984 000 ha of the area mapped and of this area $84 \%$ was burnt. Drought or recent logging destroyed the remaining $16 \%$. Only $20 \%$ was primary forest and $80 \%$ had been logged before the fire. These forests showed significant disturbance in structure; the lower and middle storeys were seriously damaged, and the upper storey was opened to a limited extent. According to the team, timber production in these forests will not be possible for at least 70 years (Schindele et al. 1989).

Heavily disturbed forests covered an area of 727 000 ha of which $88 \%$ burned. Fire destroyed the whole forest structure, from lower to upper storey. It reportedly will take several hundred years for natural succession to reach the stage of a typical rainforest ecosystem (Schindele et al. 1989).

Undisturbed peat swamp forest accounted for 181000 ha of the area mapped and 30700 ha burned. Interpretation of satellite imagery indicated that in 1988 these areas appeared undisturbed.

The Mahakam river basin had a large area of peat swamp forest (385000 ha). Of this, 97\% was severely burned during 1982-83. Much of this forested area had already been disturbed in 1982 . Drought conditions led to a lowering of the water table, causing the peat to dry out. When fire starts, peat burns easily and deeply (reports of up to $1 \mathrm{~m}$ deep in 1983) and rapidly kills off surface vegetation.

Heath forest (kerangas) is very sensitive to drought as it grows on dry, sandy soils. Schindele et al. (1989) estimated that 18000 ha of heath forest was heavily damaged by fire in 1983 .

The total area of timber plantations in 1988-89 was 27000 ha. Plantation forestry started in East Kalimantan around 1984 (Schindele et al. 1989), most (96\%) were located on areas of natural forest that burned in 1982-83.

The fires stopped spreading when they reached the mountainous areas in the west and north, where precipitation is much higher and where primary forests dominate (Schindele et al. 1989). Mapping of the extent of the fires showed that the boundary coincides with the precipitation lines and the extent of logging activities.

On the basis of the 1983 preliminary area estimates (Lennertz and Panzer 1983) and the 1989 results (Schindele et al. 1989) for disturbed and logged-over forest, a value for the burnt timber was calculated. In these calculations the timber value was set at US\$ 80/m³ (1983 price for Meranti logs) (see Box 3 for details).

\section{Causes}

Lennertz and Panzer (1983) reported that the fires were caused by small agricultural fires that escaped their bounds into nearby drought-affected secondary and logged-over forest. Clearing of land is usually carried out in the dry months of August and September when rainfall is low. This allows cut biomass to dry and become combustible, so that it is easily burned in October-November. This coincided with the start of the fire.

Subsistence farmers accounted for some of the forest clearing and burning that occurred in the East Kalimantan lowlands, but an undetermined proportion was also carried out by entrepreneurs such as peppercorn growers and land speculators (Vayda et al. 1980), for example, at Bukit Soeharto. From 1970 to 1980 , the population of East Kalimantan doubled as a result of the timber and oil booms. In addition, migrants from Sulawesi and South Kalimantan came to take advantage of the growing cash crop market and easy access to 
Box 3. Economic value of timber losses in 1982-83

\begin{tabular}{|c|c|c|}
\hline $\begin{array}{l}\text { Economic loss } \\
\text { forests }\end{array}$ & in primary ar & ogged-over \\
\hline Lightly burnt & $\begin{array}{l}680000 \text { ha } x \\
\text { US } \$ 1600 / \text { ha }\end{array}$ & $=$ US $\$ 1.088$ billion \\
\hline $\begin{array}{l}\text { Moderately } \\
\text { burnt }\end{array}$ & $\begin{array}{l}830000 \text { ha } x \\
\text { US\$ } 3200 / \text { ha }\end{array}$ & $=$ US $\$ 2.656$ billion \\
\hline Heavily burnt & $\begin{array}{l}662000 \text { ha } x \\
\text { US\$ } 6400 / \text { ha }\end{array}$ & $=$ US $\$ 4.237$ billion \\
\hline Total loss & 2172000 ha & $=$ US $\$ 7.981$ billion \\
\hline Economic loss & in swamp fores & \\
\hline Undisturbed & $\begin{array}{l}30000 \text { ha } x \\
\text { US } \$ 1600 / \text { ha }\end{array}$ & $=$ US $\$ 0.048$ billion \\
\hline Disturbed & $\begin{array}{l}375000 \text { ha } x \\
\text { US } \$ 800 / \text { ha }\end{array}$ & $=$ US $\$ 0.300$ billion \\
\hline Total loss & 405000 ha & $=$ US $\$ 0.348$ billion \\
\hline Other costs & & \\
\hline NTFPs & & US $\$ 0.373$ billion \\
\hline $\begin{array}{l}\text { Additional cost } \\
\text { of rehabilitation }\end{array}$ & & US\$ 0.373 billion \\
\hline $\begin{array}{l}\text { Total cost in } \\
\text { lost timber to } \\
\text { the national } \\
\text { economy }\end{array}$ & & US\$ 9.075 billion \\
\hline Schin & & \\
\hline
\end{tabular}

the forest offered by logging roads (Vayda et al. 1980; Kartawinata et al. 1984).

\subsection{Fires between 1983 and 1997}

\section{7}

In mid-June 1987, another drought occurred in connection with ENSO. Fortunately, the impact was not as severe as in 1982-83. Many parts of Indonesia were affected, including Kalimantan, Sulawesi, Sumatra, Bali, Nusa Tenggara and Timor. Official estimates from the Ministry of Forestry state that at least 66000 ha of forest area burnt in 1987.

\section{Kalimantan}

Central Kalimantan suffered bad smoke haze, and as a result the provincial airport was closed for two weeks. In West Kalimantan, there were reports of newly established transmigration settlements being destroyed by fire. In East Kalimantan, fires destroyed forest lands along the road between Samarinda and Balikpapan. Official figures from Kanwil Kehutanan stated that 1459 ha of forest land burned, including forest concessions, timber estates and protected forest. Most of the fires were blamed on shifting cultivators. It was reported that burning coal seams were responsible for fires in some rubber plantations and protected forest areas, such as Bukit Soeharto (Box 4). In late September, the central government took steps to extinguish the fires at Bukit Soeharto, where a substantial part of the area burned. This area was also badly burned in the 1982-83 fires. For the first time in Indonesia, aerial water bombing technology was used to extinguish these fires; however, lack of skills and coordination hampered its effectiveness.

\section{Box 4. Bukit Soeharto}

Bukit Soeharto has drawn much international attention over the years. It was decided to designate the area as a protected area and to develop it as a source of diverse tropical tree species. Initially an area of 23000 ha was set aside under the status of protected forest. This was increased to 56000 ha and finally to 76000 ha in 1988 , when it was designated a recreation park and protected area. When the area was enlarged, some settlements and pepper fields were included, which has led to increased threats to the area. Interests in the area are many. Fires badly damaged this area in 198283, 1987, 1991, 1994 and 1997-98.

The Ministry of Forestry blamed shifting cultivators for causing the fires, while environmentalists blamed it on poorly managed forests (SKEPHI 1992). 
1991

Fires started in June-July as land clearing commenced. Uncontrolled burning escalated in September and October, causing widespread smoke haze. Fires were recorded in Sumatra, Kalimantan, Sulawesi, Java, Bali and Nusa Tenggara. Fires resumed in March-April 1992 in several provinces.

Estimates by MoF put the amount of burnt forest land at 120000 ha, including at least 5000 ha of timber estates, with damages amounting to more than Rp. 173 billion. However, the State Minister for Environment placed the total burnt area at more than 500000 ha.

Smoke haze disrupted transportation, contributed to a decline in tourism and caused health problems. It also led to accidents on land and sea and in the air. In a 2-month period, Merpati, Indonesia's second largest domestic carrier, had to cancel 337 flights, incurring losses of Rp. 6.5 billion.

Impacts of the smoke haze were felt in neighbouring Malaysia and Singapore. Malaysia stated that this was the worst smoke haze in 10 years and that the population was experiencing health problems as a result. This situation prompted Indonesia and Malaysia to mobilise ASEAN in an attempt to deal with the problem. Appeals were also made to western countries and Japan for assistance in combating the fires.

\section{Sumatra}

Fires occurred in the provinces of South Sumatra, Jambi, Lampung and Riau. In South Sumatra, at least 7500 ha of forest land burned. This area included natural forest, plantation forest and reforested areas. Many of these fires were deliberately started to clear land for planting (SKEPHI 1992). Fire in natural forests was mainly in logging concessions. Only $30 \%$ of the burnt area was classified as smallholder land. The most serious fires were in peat areas. In Jambi, 470 ha of plantations burned. Visibility in the provincial capital was down to $50 \mathrm{~m}$ in June. In Lampung,
17000 ha (MoF 1998) was burnt, of which 2400 ha was HTI and 2000 ha in the Way Kambas National Park. In Riau, most fires were caused by land clearing for plantations. Smoke haze was particularly bad and severely affected human health and transportation.

\section{Central Kalimantan}

This province recorded the largest area affected by fire, followed by Riau and East Kalimantan. The damage was finally estimated at 18000 ha by the MoF (MoF 1998), although this may be an underestimate.

\section{East Kalimantan}

Most fires occurred in the period AugustSeptember. According to an official report by MoF, the total burnt area was 3750 ha. However, a provincial forestry official said that 5500 ha of forest was affected by fire and much of this was caused by the irresponsible actions of private companies (SKEPHI 1992). According to the same source, most serious fire damage was seen in forests that had been converted to other uses such as plantations. SKEPHI (1992) reports that at least 9297 ha burned, including areas of Bukit Soeharto and forest concessions, with a timber loss of US\$4.5 million.

According to the results of a JICA mission in November 1991, the major causes of fire were slashand-burn agriculture, discarded cigarettes and burning crops on coal seams. Fire fighting attempts by the army, concession holders and local farmers were observed. Much of the burnt forest was of a secondary type, with alang-alang grasses. Primary forest exhibited a high resistance to fires, with most of the fires burning ground-level vegetation.

In the Bukit Soeharto area, 35 coal seam fires were noted by the JICA mission. In 1987, much of the blame for the fires in Bukit Soeharto was placed on coal seam fires, but in 1991 human carelessness was cited as the main factor. A local NGO representative said fires were deliberately started 
in the area by pepper farmers who had been forcibly evicted from the area in 1987.

\section{South Sulawesi}

The official MoF estimates for area burnt was 1650 ha (MoF 1998). Fire fighting was carried out mainly by local farmers in the vicinity of forest areas. The burnt vegetation consisted of planted forests of merkusi pine, eucalyptus, acacia and albizia, and their resistance to fire was low.

\section{Java}

The State Forestry Corporation (Perum Perhutani), which manages forests in Java, reported that by October 1991, 21000 ha of its forests was damaged by fire. MoF (1998) reported 19662 ha burnt in Central Java, most of it in teak plantations; in East Java 13000 ha burnt, mainly in areas of pine forest on mountain slopes, and 2400 ha in West Java. Teak plantations were the worst affected. A substantial amount of blame was placed on land clearing by plantation timber estate owners and smallholders. The government attributed most of the blame to shifting cultivators.

\section{4}

There were widespread fires in Kalimantan and Sumatra in 1994 and smoke haze blanketed much of Kalimantan. Fires were reported to be most widespread in Central Kalimantan where, according to official estimates, it affected at least 80000 ha (The Jakarta Post, 1/10/94). According to official estimates from the MoF, 5.11 million ha of forests, brush, and grasslands burned. The Minister of Forestry stated that, of this, 4.6 million ha were in slash-and-burn areas and only 435600 ha was burned at the hands of forest concessionaires, plantation owners and transmigrants (The Jakarta Post, $7 / 10 / 94)^{1}$. Official figures were released later by the MoF (Table 1 ).

Total financial losses in timber estates were estimated at US\$ 15.4 million by the MoF (The Jakarta Post, 10/10/94). The smoke haze caused
Table 1. Burnt area estimates for 1994

\begin{tabular}{l|r}
\hline $\begin{array}{l}\text { Land Cover/ } \\
\text { Land Use Type }\end{array}$ & $\begin{array}{c}\text { Size of Area } \\
\text { Burnt (ha) }\end{array}$ \\
\hline Traditional dry land farming & 2800000 \\
Shifting cultivation & 1500000 \\
\hline $\begin{array}{l}\text { Transmigration areas } \\
\text { (farming and settlements) }\end{array}$ & 300000 \\
\hline Plantations & 221000 \\
\hline Reforestation areas & 20500 \\
\hline Timber estates (11 000 ha in & 17000 \\
South Sumatra) & 8000 \\
\hline Natural forests & $\mathbf{4 8 6 5 0 0}$ \\
\hline Total Area Burnt & \\
\hline
\end{tabular}

Source: Ministry of Forestry

health problems and paralysed air transport in a number of provinces. An official statement by the Minister of Forestry stated that the government had suffered Rp. 50 billion in losses as a result of smoke and fires in natural forests and regreening forests (The Jakarta Post, 7/10/94).

The only in-country monitoring with daily satellite imagery (NOAA AVHRR) was carried out by the Indonesia-UK Tropical Forest Management Programme, which had installed a receiving system in Central Kalimantan (Schneider 1995). According to this source the majority of fires occurred at the forest/agricultural land interface, rather than in the middle of large expanses of forest. Peat swamp forest also appeared to be particularly susceptible, and these fires burned over a long period, producing a lot of smoke.

Smoke from fires in Sumatra reduced the average visibility over Singapore to less than $500 \mathrm{~m}$ by the end of September. The situation was similar in Peninsular Malaysia, Sarawak and Sabah. An

${ }^{1}$ This figure of 5 million ha was rarely quoted in 1997. In 1997, the 1982-83 fires were cited as having been the worst, compared with only 161000 ha of land destroyed in 1994 (The Jakarta Post, 27/8/97). In another Jakarta Post article, this area estimate is referred to as 'forest land', not just 'land'. 
ASEAN report (ASEAN 1995) revealed the results of a study showing that asthma attacks among children showed a high concentration of fire-generated carbon monoxide, nitrogen dioxide and other suspended particulate matter.

Officially, the government blamed 'nomadic tribes' practising slash-and-burn agriculture; NGOs blamed forest concessionaires and plantation companies; and concessionaires blamed the weather (The Jakarta Post, 1/10/94 and 3/10/94). The Minister of Forestry stated that arson might be behind some of the forest fires in Sumatra and Kalimantan as a result of tensions between indigenous people and concessionaires and plantation holders (The Jakarta Post, 27/9/94). The Minister later stated that $85.2 \%$ of the fires in Sumatra and Kalimantan had been started by local and nomadic farmers who still practise traditional methods of clearing land (The Jakarta Post, 7/10/ 94 and 10/10/94).

\subsection{Fires in 1997}

Early in 1997, scientists predicted a severe El Niño and issued warnings of a pronounced drought. The dry season began around the middle of May in Indonesia, and farmers, plantation operators and forest concession holders began normal dry season burning activities. In June/July, the State Minister of Environment and Coordinating Minister for People's Welfare issued warnings of a drought, but to little avail. By September many uncontrolled fires were burning in Sumatra and Kalimantan, and thick smoke haze covered Sumatra, Kalimantan, Malaysia and Singapore. President Soeharto ordered all land clearing activities to be stopped. On 25 September 1997, the President declared the land and forest fires a national disaster and ordered mobilisation of the people. It is interesting to note that as early as December 1996, on National ReGreening Day, the Minister of Forestry had announced guidelines for the prevention of forest fires and said the government had issued a reminder that land clearing should be done without fire, or legal action would be taken against the perpetrators (Media Indonesia, 21/9/97).

Many climatologists predicted that the El Niño at this time could be the worst ever; some went so far as to call it 'The Climate Event of the Century'. A comparison of the SOI for 1982-83 and 1997-98 shows that there was a much sharper drop into negative values in the 1997-98 El Niño compared with the pronounced El Niño of 1982-83 (Figure 2). However, by July 1997 the path it followed was more moderate than in 1982-83. In May-June 1998, the current El Niño was waning, as shown by the increasingly positive SOI values.

\section{Burnt area estimates}

Unlike in previous El Niño years, several government agencies and donor projects were in a good position to provide information on the location of fires through analysis of satellite imagery and fire hot spot maps. In early September, the government was quoting a figure of 300000 ha for forest burned so far in 1997 (The Jakarta Post, 1/ 9/97), and by early October the figure had risen to 600000 ha (The Jakarta Post, 6/10/97). ${ }^{2}$ According to preliminary estimates from the European Union Fire Response Group (EUFREG), an area (land and forest) in excess of 2 million ha may have been burnt in 1997 in Indonesia as a whole (Trigg 1997). ${ }^{3}$ Based on limited observations in southern Sumatra it was estimated that the total area of forest (disturbed and/or logged primary forest and dense secondary forest) burnt in the whole of Indonesia was probably in the range 150 000 to 300000 ha. (EU FLB 1997). It was also estimated that $80 \%$ of the total smoke was produced

\footnotetext{
2 This figure is quoted as land burned, but it is unclear whether this includes forest. During the research for this document the terms 'forest fires', 'forest and land fires' and just 'fires' were seen to be used freely to mean the same thing. It many cases the author had no way of knowing exactly what was being referred to in such reports

${ }^{3}$ This crude estimate was extrapolated from a figure of 1 million ha burnt in South Sumatra and Lampung.
} 
Figure 2. SOI for 1982-83 and 1997-98 compared

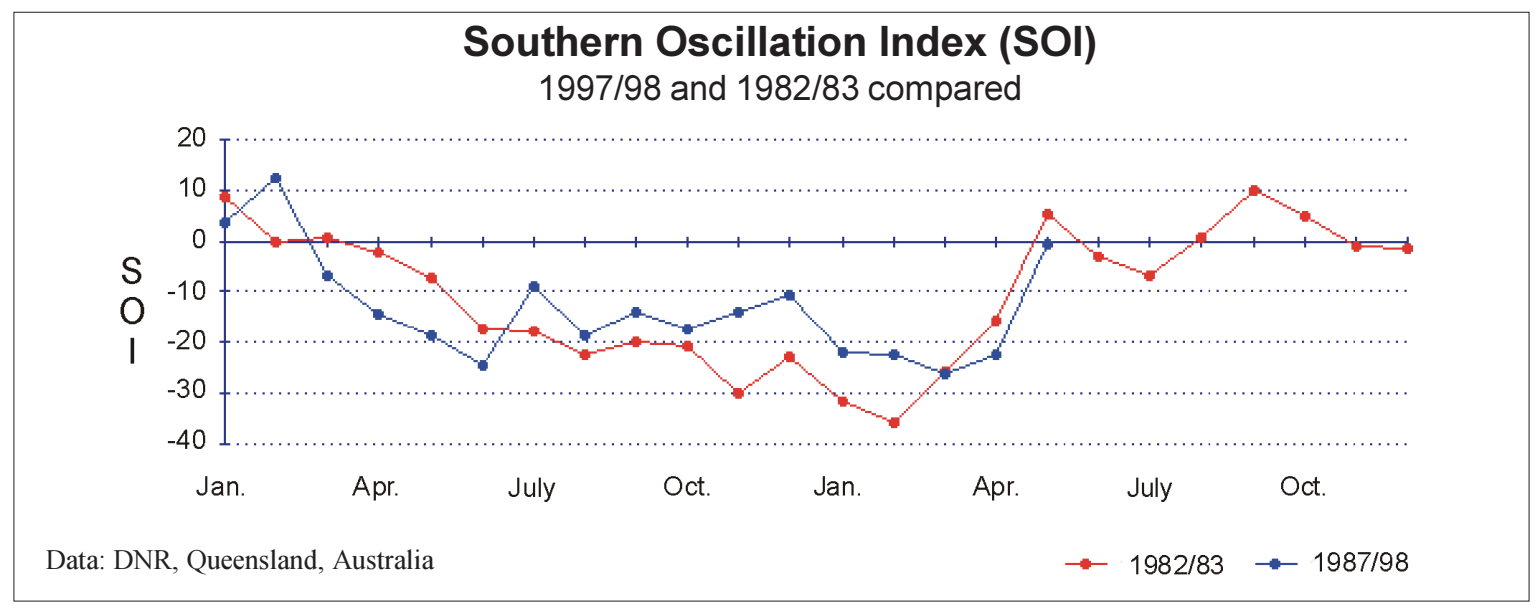

Note: Although the data are for Queensland, Australia, they give a good indication of the Indonesian situation.

Source: NOAA website, http:///www.pmel.noaa.gov

by seven clusters of fires in and around peat forests in Sumatra and Kalimantan (Legg 1997). These fires burned from at least early September.

A more recent estimate from the $\mathrm{EU}$, based on interpretation of satellite imagery in selected areas, indicates that 2.3 million ha burned in South Sumatra alone (Ramon and Wall 1998). The vegetation types burnt were, in descending order of area affected, wetland vegetation cleared for rice, secondary bush, scrub and herbaceous swamp lands, dry land shifting agriculture, and grassland in coastal peat swamps.

For Kalimantan burnt area estimates from analysis of remotely sensed imagery became available in 1998. These estimates were derived using different methodologies and the results differed quite widely. The Centre for Remote Imaging, Sensing and Processing (CRISP) at the National University of Singapore derived estimates for Kalimantan and Sumatra by interpreting SPOT quicklooks. ${ }^{4}$ It calculated that approximately 1.5 million ha had burned in Sumatra, and that approximately 3 million ha burned in Kalimantan (Liew et al. 1998). The WWF Fire Project used NOAA-AVHRR in conjunction with Defence Meteorological Satellite
Program (DMSP) imagery (Fuller and Fulk 1998). They estimated that between 1.97 and 2.3 million ha burned in Kalimantan between August and December 1997. Of this about 811000 ha were in lowland forest, 380000 in Swamp Forest, 420000 in unproductive dryland, 310000 unproductive wetland, 261000 was agriculture and 42000 of plantations.

Giving a figure many orders of magnitude smaller, the Ministry of Forestry (MoF 1998) officially stated that 263992 ha of designated forest land had burned in 1997. An official estimate from the State Ministry of Environment states that approximately 400000 ha of forest and other land was burnt in 1997 (KLH 1998). The report indicates that $85 \%$ of the burning was caused by oil palm plantation companies, industrial plantations and logging concessions. Table 2 shows the breakdown of this estimate into forest and non-forest land.

${ }^{4}$ A 'quicklook' is the term used to describe an image product that is a subsampled version of the full-resolution image. Quicklooks are used as browse products (often on the Internet) for previewing an image before the customer decides to buy the full-resolution product. 
Table 2. Estimates of forest and non-forest land that burned in 1997

\begin{tabular}{lr}
\hline Forest or Land Status & $\begin{array}{r}\text { Total Area } \\
\text { Burnt (ha) }\end{array}$ \\
\hline Protection Forest & 21963 \\
Production Forest & 163444 \\
Nature Reserves and & 17238 \\
Wildlife Sanctuaries & \\
Recreation Forest & 1415 \\
National Parks & 54331 \\
Grand Forest Park & 653 \\
Research Forests & 4741 \\
Urban Forest & 5 \\
Hunting Park & 263992 \\
Total Forest Land & 16186 \\
Non-forest land cleared & 8444 \\
by burning & 88237 \\
Burnt by escaped fires & 4391 \\
Plantations* & $\mathbf{1 1 7} 258$ \\
Other & 381250 \\
\hline Total Non-Forest Land & \\
\hline Overall Total Burnt & \\
\hline
\end{tabular}

* Oil palm (36 690 ha), rubber (19 750 ha), coconut (5718 ha), coffee (546 ha), sugar cane (4769 ha), cacao (205 ha), jambu (74 ha) and other (20 485 ha).

Sources: State Ministry of Environment; KLH (1998)

These widely varying estimates of total area burnt show that there is still much work required just to answer the basic question of how much burned.

\section{Worst affected areas}

\section{Central Kalimantan}

Most of the fires in this badly affected province were located in the coastal areas and along the larger rivers. There were dense clusters of fires in the Pangkalanbun and Sampit areas. Some of the fires were located in the Tanjung Puting National Park that contains peat swamp forest. Many hot spots were detected in the " 1 Million Hectare Rice
Project' area, where peat was burning following forest clearing.

\section{West Kalimantan}

Most of the fires were concentrated in the southern part of the province, in the Ketapang regency. There was a large cluster of long-burning peat fires, and it is thought that areas of peat swamp forest were burning. The already severely degraded Muara Kendawangan Nature Reserve had many hot spots during September. Smoke haze obscured much of West Kalimantan for long periods, so there was little and infrequent fire hot spot information for other regencies.

\section{South Kalimantan}

There were many long-duration fires on the south coast, where agriculture is the main activity.

\section{East Kalimantan}

There were moderate fires in East Kalimantan during 1997, certainly not to the extent of those that would follow in 1998.

\section{Sumatra}

Fires were concentrated in eastern Riau (in peat areas), eastern Jambi, northern Lampung and most of South Sumatra. There were some fires in North Sumatra. A large percentage of the total smoke haze was produced by clusters of fires in peat areas in eastern Jambi and South Sumatra. These fires had burned from at least early September until late October. The national parks of Berbak in Jambi and Way Kambas in Lampung had serious peat fires. The European Union Fire Project calculated the areas burnt in southern Sumatra (Table 3).

\section{Sulawesi}

There was not routine hot spot coverage of the island, as most interest was focussed on Sumatra and Kalimantan. In general, fires in Sulawesi were 
Table 3. Relative proportions of areas and numbers of hot spots for different land classes in southern Sumatra from EUFREG Phase I

\begin{tabular}{l|rc|cc|cc|cc|}
\hline \multirow{2}{*}{ Province } & \multicolumn{2}{|c|}{ HPH } & \multicolumn{2}{c|}{ HTI } & \multicolumn{2}{c|}{ Transmigration } & \multicolumn{2}{c}{ Forest } \\
\cline { 2 - 10 } & $\begin{array}{c}\text { Area } \\
(\%)\end{array}$ & $\begin{array}{c}\text { Hot spots } \\
(\%)\end{array}$ & $\begin{array}{c}\text { Area } \\
(\%)\end{array}$ & $\begin{array}{c}\text { Hot spots } \\
(\%)\end{array}$ & $\begin{array}{c}\text { Area } \\
(\%)\end{array}$ & $\begin{array}{c}\text { Hot spots } \\
(\%)\end{array}$ & $\begin{array}{c}\text { Area } \\
(\%)\end{array}$ & $\begin{array}{c}\text { Hot spots } \\
(\%)\end{array}$ \\
\hline South & 25.2 & 29.5 & 7.2 & 15.3 & 1.2 & 1.0 & 40.8 & 45.8 \\
Sumatra & & & & & & & & \\
Jambi & 50.5 & 54.1 & 4.2 & 6.9 & 1.5 & 1.9 & 58.9 & 65.3 \\
Lampung & 0.9 & 2.5 & 0.9 & 1.4 & 0.3 & 1.0 & 19.0 & 19.9 \\
Bengkulu & 16.4 & 20.8 & 0.4 & 0.0 & 0.6 & 0.0 & 57.0 & 63.3 \\
\hline
\end{tabular}

Source: after Legg (1997)

much less serious than in Kalimantan or Sumatra. There were few fires in natural forest areas or protected areas.

\section{Irian Jaya}

No source of hot spot maps for Irian Jaya was available. However, press reports of droughts and smoke pollution images from the TOMS satellite suggest there were large fires on the southern coast. The MoF (1998) estimated 30000 ha of burnt forest land.

\section{Java}

Fires were reported to be raging on a number of mountains in Central Java in areas of natural forest. The MoF (1998) estimated 28000 ha of burnt forest land.

\section{The causes}

This time, large-scale plantation and timber estates were immediately blamed for the fires and smoke. In late July, the Minister of Forestry was quoted as saying that 'We can tolerate local people clearing land in a traditional way by burning the forest, but plantation companies can afford other ways of clearing' (The Jakarta Post, 29/7/97). It is widely believed that much of the smoke haze emanated from burning as a means of clearing the land for pulp and oil palm plantations. Clearing land by burning is illegal in Indonesia, but poor law enforcement allows the method to continue virtually unchecked. Government policies actively encourage the conversion of land to plantations. According to Sunderlin (1998), there are currently 2.4 million ha of oil palm plantations in Indonesia, with an estimated 1.5 million ha planned for 1998 . The Minister of Agriculture estimated that $80 \%$ of the land and forest fires were caused by plantation companies (The Jakarta Post, 2/9/97). Poor logging practices, which often leave natural forest vulnerable to fire, were also blamed.

In September, the government made an effort to control the clearing activities of forestry companies. After data were obtained from hot spot information and satellite imagery, 133 plantation companies, 27 timber estates and 15 transmigration programmes were given a 15-day ultimatum to stop burning (The Jakarta Post, 18/9/97) (Table 4). They were warned that if they could not prove their innocence, their licences would be revoked and they would face legal consequences (The Jakarta Post, 18/9/97).

Potter and Lee (1998) attempted to examine the role of plantations in causing forest fires in Kalimantan. They concluded that the burning situation differed for each province. Oil palm companies played a larger or smaller part depending on location and stage of development. Potter and 
Table 4. Timber and plantation companies warned for burning land

\begin{tabular}{l|l}
\hline Province & $\begin{array}{l}\text { No. of Companies } \\
\text { Warned }\end{array}$ \\
\hline North Sumatra & 16 \\
South Sumatra & 17 \\
Jambi & 20 \\
Riau & 31 \\
Central Kalimantan & 35 \\
South Kalimantan & 11 \\
East Kalimantan & 18 \\
West Kalimantan & 27 \\
\hline
\end{tabular}

Source: Director General of PHPA quoted in The Jakarta Post, 18/9/97

Lee warn that the desire of provincial authorities to convert land to oil palm, gives them an indirect role in causing fires.

In a short description of the 1997 fires around Lake Jempang on the Mahakam river, Gönner (1997) describes some of the possible causes of the fires. It was observed that most of the fires in the area occurred in cultivated forest areas (rattan, fruit and rubber) and the scrub vegetation around the lakes. PT. London Sumatra (oil palm company) had recently been granted an extension in this area, and it was noted that local farmers' gardens in this area were burning. Gardens outside the plantation area were not burning. Many locals blamed the oil palm company for the fires and felt they were cheated by the company. According to Gönner (1997), in the company's view a burnt fruit tree did not require compensation. Local Dayak farmers insisted they had considered the conditions too dangerous to clear land and had not set fires for that reason. However, in another area, a fire that burned many village gardens apparently was set deliberately by locals as an act of revenge (Gönner 1997). Gönner (1998) writes that in many cases, disputes over land tenure were the crux of the issue and that 'conflicts could be resolved by fire'.

In the socio-economic survey carried out by the ADB TA Project. They found that $69 \%$ of community members interviewed in Riau and East Kalimantan reported that fires came from outside their own land (ADB 1999). The project deduced that few people were prepared to identify the causal agent. They also noted a tendency for community members to act carelessly with fire in and around forest concessions, HTIs, and estate crop plantations. This behavior was attributed to jealousy on the part of the local community as a result of rapid area expansion by companies who have little regard for local societies (ADB 1999).

Perhaps one of the most complex and yet critical factors contributing to the fires is land tenure. Apart from intentional land clearing and accidental burning, arson is now also cited as one of the causes. The 1997 fires highlighted that land tenure insecurity, changes in land use policies and the interaction between smallholder and largeholder are considered important variables in assessing the underlying causes of fires and deforestation in general.

In previous years the social and physical impacts of the fires were rarely assessed. However State Ministry of Environment/UNDP (1998) provides a detailed analysis of these impacts for the 1997 fires.

\section{Economic costs}

The economic losses experienced by Indonesia and other ASEAN countries as a result of the fires and smoke haze were immense. WWF-ID and the Economy and Environment Programme for South East Asia (EEPSEA) quickly started to quantify the economic losses. The initial study addressed impacts during the period 1 August-31 October 1997, and concerned only costs related to haze. The interim results were released in late February 1998 (EEPSEA and WWF 1998a). According to this report, the cost of the haze to Indonesia, Malaysia and Singapore was US\$1.4 billion. The authors were quick to point out that the losses they calculated were based only on available data and the figure did not fully capture the economic impact of the fires and haze. Among the costs not included were long-term health costs and loss of forest resources. 
In May 1998, EEPSEA and WWF-ID released an updated version of their estimate of the economic cost of the fires and haze (Tables 5a and 5b) (EEPSEA and WWF 1998b). Unlike the previous estimate in February 1998, this included fire-related costs.

Table 5a. Fire-related damages (US\$ millions)

\begin{tabular}{|c|c|c|c|}
\hline $\begin{array}{l}\text { Tvpe of } \\
\text { Loss }\end{array}$ & $\begin{array}{l}\text { Loss to } \\
\text { Indonesia }\end{array}$ & $\begin{array}{l}\text { Loss to } \\
\text { Other } \\
\text { Countries }\end{array}$ & Total \\
\hline Timber & 493.7 & - & 493.7 \\
\hline Agriculture $^{a}$ & 470.4 & - & 470.4 \\
\hline $\begin{array}{l}\text { Direct forest } \\
\text { benefits }\end{array}$ & 705.0 & - & 705.0 \\
\hline $\begin{array}{l}\text { Indirect } \\
\text { forest } \\
\text { benefits }\end{array}$ & 1077.1 & - & 1077.1 \\
\hline $\begin{array}{l}\text { Capturable } \\
\text { biodiversity }\end{array}$ & 30.0 & - & 30.0 \\
\hline $\begin{array}{l}\text { Fire fighting } \\
\text { costs }\end{array}$ & 11.7 & & 25.1 \\
\hline $\begin{array}{l}\text { Carbon } \\
\text { release }\end{array}$ & - & & 272.1 \\
\hline Total Fire & 2787.9 & 285.5 & 3073.4 \\
\hline
\end{tabular}

Notes:

a. Losses to plantations and smallholdings

b. Storm protection, water supply and regulation, erosion control, soil formation, nutrient recycling, and waste treatment.

c. Potential income lost to Indonesia from international conservation expenditures, that is, from international agencies and NGOs willing to pay to conserve tropical forests. It does not reflect the cost in loss of biodiversity. Source: EEPSEA and WWF (1998b

Table 5b. Haze-related damages (US\$ millions)

\begin{tabular}{l|cc|r}
\hline $\begin{array}{l}\text { Tvpe of } \\
\text { Loss }\end{array}$ & $\begin{array}{l}\text { Loss to } \\
\text { Indonesia }\end{array}$ & $\begin{array}{l}\text { Loss to } \\
\text { Other } \\
\text { Countries }\end{array}$ & Total \\
\hline $\begin{array}{l}\text { Short term } \\
\text { health }\end{array}$ & 924.0 & 16.8 & 940.8 \\
$\begin{array}{l}\text { Tourism } \\
\text { Other }\end{array}$ & 70.4 & 185.8 & 256.2 \\
\hline Total Haze & $\mathbf{1 0 1 2 . 0}$ & $\mathbf{3 8 4 . 1}$ & $\mathbf{1 3 9 6 . 1}$ \\
\hline
\end{tabular}

Source: EEPSEA and WWF (1998b)
Total Cost of Fire and Haze 1997
To Indonesia:US\$
3.8 billion (85\%)
To other countries:
US\$ 0.7 billion (15\%)

TOTAL US $\$ 4.5$ billion

\subsection{Fires in 1998}

In mid-November 1997, rain started to fall over Kalimantan and Sumatra. After this short respite, dry weather conditions returned to East Kalimantan in early January 1998; other provinces in Kalimantan, northerly parts of East Kalimantan, and Sumatra experienced normal to heavy rainfalls. The dry conditions in East Kalimantan prevailed until late April, contributing to drought and fire conditions. At this time, the drought was beginning to cause food shortages as a result of poor harvests and total failure of the rice crop in some areas.

In January and February, there were also renewed outbreaks of fires in South Sumatra and Riau, but these did not escalate to the extent of those in East Kalimantan. During February and March, there were fires in Sabah, Brunei and Sarawak. These conditions were in line with El Niño weather predictions, which stated that weather anomalies in Indonesia would not diminish until some time between March and July 1998.

Beginning in February, thick smoke haze blanketed large areas of East Kalimantan. The main coastal towns of Balikpapan and Samarinda received some respite from winds blowing from the sea, which cleared the smoke a little. However, on 21 March, the visibility in Samarinda was down to $50 \mathrm{~m}$ and air pollution levels were very high.

The GTZ-Integrated Forest Fire Management Project (IFFM) issued a fire danger warning on 15 January 1998, and a few days later the governor put the province on high alert again. The situation was closely monitored using the NOAA/AVHRR receiver in Samarinda, and daily fire hot spot maps were available on the IFFM Web site. The number of hot spots rose sharply at the end of January. They were mainly concentrated in the central parts of East 
Kalimantan $(150 \mathrm{~km}$ north and $100 \mathrm{~km}$ south of the Mahakam river). According to IFFM, by early February the situation had escalated to the extent that the fires were already far beyond any suppression capabilities (Schindler 1998). The fires continued to spread during March, and at the end of the month the IFFM Web site was reporting the existence of more than 1000 hot spots.

The situation was so serious in East Kalimantan that the State Minister of the Environment compared the lack of government control of the fires to the lawlessness of the American Wild West, and regretted his inability to create a sense of urgency among government officials (Reuters, 14/4/98).

In mid-April, the United Nations Disaster Assessment and Coordination team estimated that at least 10000 fire fighters supported by water bombers would be required to put out the fires (UN OCHA 1998a). Towards the end of April, UNEP convened a meeting of environmentalists, government officials and donors in Geneva to discuss ways of controlling the fires in Indonesia. A US\$ 10 million package was approved, but the fires subsided before funds could be mobilised (Straits Times, 20/6/98).

Heavy rains started to fall in late April, extinguishing many of the fires. A few sporadic fires have since broken out in a number of locations, but by mid-June experts agreed that El Niño was weakening its grip (Reuters, 18/6/98).

\section{Burnt area estimates}

The impression of the burning areas acquired from helicopter flights by IFFM/BAPEDAL/MoF staff in early February was 'terrifying'. 'Small and large fires were burning everywhere.' After this flight, estimates of 15000 to 20000 ha burned and 5000 ha still actively burning were issued by IFFM. The burnt and burning areas were grassland, brushland, degraded forests, secondary forest and huge areas of Macaranga stands, with surface fires burning in primary forest. The official figure for total burnt area currently stands at 550000 ha, although the actual figure is likely to be much larger. The IFFM issued a preliminary guess that the burnt area might equal that of 1982-83 (Schindler 1998). At the end of October 1998 IFFM presented estimates for areas burned in East Kalimantan between January and end of April 1998. The total area burned was 4 million ha (Siegert and Hoffmann 1998). They obtained this figure by extrapolating from the results of classifications on their 2 million ha study area. In this study area 102000 ha were completely destroyed, 1230600 ha were severely damaged and 532590 slightly damaged. It would seem that the largest areas burned in terms of land use were logging concessions (742 $600 \mathrm{ha}$ ) and plantations (518 500 ha). The area burned includes most of the peat and freshwater swamp forest lands in East Kalimantan, almost all of Kutai National Park, and part of the unique limestone forest areas of the Sangkulirang peninsula.

\section{The causes}

Based on field surveys and remotely sensed imagery, the government began to take legal action against 15 concession companies for starting fires on their land. On March 17, a large palm oil company, PT London Sumatra, was finally convicted of large-scale illegal land conversion in the vicinity of the Mahakam lakes.

From preliminary ground and aerial surveys carried out in April, it would appear that the areas most affected by fire in 1998 coincide with those worst affected in 1982-83. ${ }^{5}$ There were reports of HPHs, HTIs and plantations exhibiting large areas of burning, as much as $50 \%$ of total area. By the middle of February, 2500 ha of the 200000 ha Kutai National Park had burned. It was reported that these fires were started by farmers clearing land (The Jakarta Post, 16/2/98). The estimate now stands at 77000 ha burned in Kutai NP (Reuters, 18/6/ 98). The MoF concentrated its fire fighting efforts

\footnotetext{
${ }^{5}$ Personal communication, Anja Hoffman, NOAA specialist, IFFM, 23 May 1998.
} 
in Kutai NP and Bukit Soeharto Forest Reserve. Fire fighting in forest and plantation concessions was the responsibility of the owners (The Jakarta Post, 24/2/98).

In late January 1998, a WWF team carried out a short survey of fire causes in the Mahakam Lakes area (Deddy et al. 1998). In the vicinity of the Muara Kaman Nature Reserve and the Mahakam lakes, it was reported that fires around lakes and along some rivers had been deliberately set by local people. The reason was to clear areas of swamp vegetation for fishing, thereby making it easier to catch fish and set nets during high water. This appeared to be a customary activity during the dry season. Similar findings are reported from the Sentarum Lakes in West Kalimantan (Luttrell 1994).

The WWF team also found fires in industrial plantation areas. Interviews with local people suggested that the fires had been started deliberately by the plantation company as a means of land clearing. However, the company workers denied this, insisting the fires had jumped across from outside the plantation. They had no means to put out the fires. There was also evidence, from interviews and on the ground, that the company had deliberately burned land traditionally claimed by local people and overlapping with the plantation. Once the land was burned, there was no requirement to pay compensation to local people for loss of crops, rubber, bamboo and rattan.

\section{Economic costs}

Towards the end of April, the government estimated that timber revenue losses from fires in East Kalimantan in 1998 had reached US\$1.06 billion (The Jakarta Post, 27/4/98). Thorough estimates of the cost of the drought and fires of 1998 have not yet been calculated. Despite the magnitude of the losses incurred, the fires in East Kalimantan ranked fifth on the government's crisis handling agenda, according to the State Minister of Environment (The Jakarta Post, 20/4/98). Fire disaster handling was placed after programmes for poverty alleviation, employment generation, public health care and stabilisation of the rupiah.

The ADB TA Project has recently released the results of a study on the total economic cost of the 1997/98 drought and fires (ADB 1999). The total losses are estimated at between USD 8.5 and 9.4 billion, with an average of USD 9 billion. Table 6 summarises these results.

Table 6. Economic Losses due to 1997/1998 drought and fires (ADB 1999)

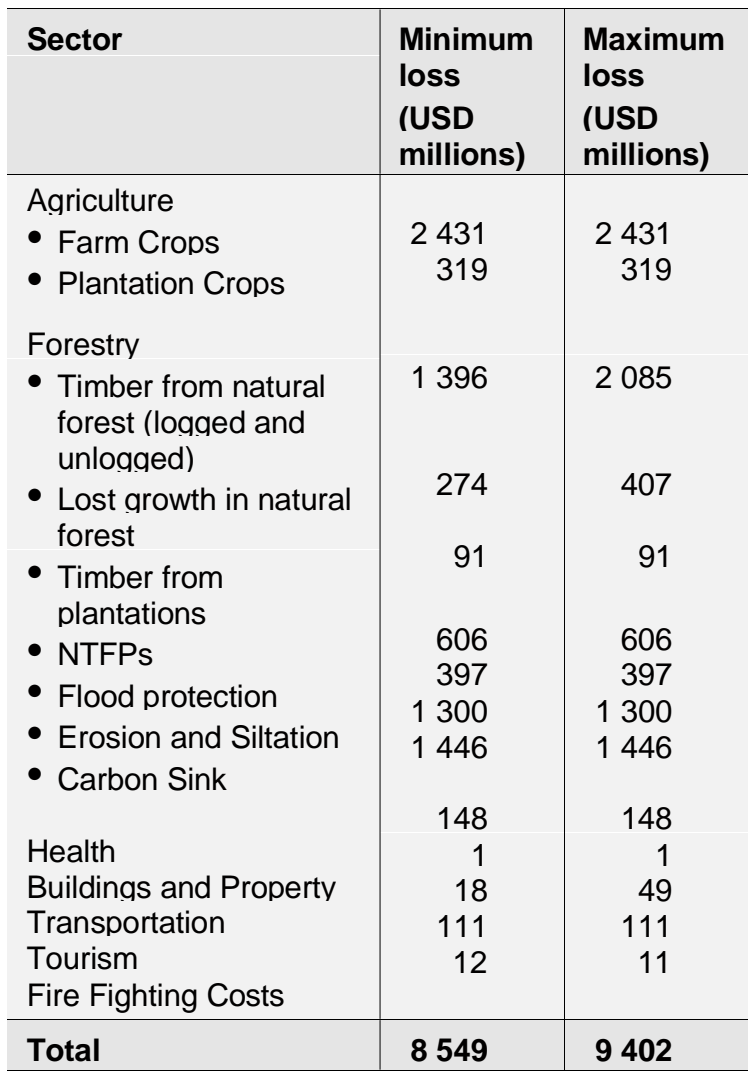




\section{Forest Fire Activities of Donor Countries prior to 1994}

From the literature, it would seem that the fires of 1982-83 were the first to bring world attention to Indonesia in terms of forest and land fires. Since then, numerous reports have been written, seminars and training courses given, fire fighting equipment distributed, and a number of short- and long-term fire assessment and management projects undertaken.

Hartono and Sato (1993) carried out a comprehensive review of the forest fire projects in Indonesia from 1982 until 1993. Much of the information in the following section was obtained from their report; however, in some cases information was augmented by reference to the original project documents. The description provided here is categorised by donor (country), followed by a brief description of the mission, seminar or project. Projects that started prior to 1997 but are still ongoing are discussed in Chapter 3.

\subsection{Fire Projects}

\section{FAO}

\section{Forest Fire Management, Technical}

\section{Cooperation}

May 1992-December 1993 (TCP/INS/2253 A)

Objective: Provide assistance in strengthening the institutional capacity of MoF in forest fire management through a pilot scheme.

Activities: Prevention (awareness materials); presuppression (fire management plan, fire history, fuel types, access, land use practices); suppression (purchase equipment, fire fighting training).

Results: Purchased fire hand tools and communications equipment for Baluran National
Park, East Java, and Way Kambas National Park, Lampung; printed fire prevention materials (stickers, posters, leaflets); conducted training in use of equipment; produced fire prevention plan for Baluran and Way Kambas.

\section{Germany}

2a. Preliminary Assessment of the Drought and Forest Fire Damage in East Kalimantan

In October 1983, the Indonesian authorities asked GTZ to assist in funding a fact-finding mission to obtain more reliable estimates of the burnt areas and the damage caused in 1982-83 (Lennertz and Panzer 1983). The study was carried out by GTZ within the framework of the Transmigration Area Development Project.

The mission team consisted of experts from GTZ, MoF, PHPA and the Forestry Faculty of Mulawarman University in Samarinda. The mission was completed within 5 weeks. The goals of the mission were:

- to determine the cause of the forest fires;

- to determine the areas affected and the intensity of the damage;

- to assess the consequences for the environment, forestry and forest industries and future land use planning; and

- to propose measures and actions for reducing or overcoming the effects of drought and fires.

2b. Investigation of the Steps Needed to Rehabilitate the Areas of East Kalimantan Seriously Affected by Fire

In October 1988, ITTO (with a contribution from GOI) financed a one-year study of the steps needed 
to rehabilitate the areas of East Kalimantan seriously affected by fire (Schindele et al. 1989). GTZ was charged with implementing the technical assistance for this study. The Agency for Research and Development (LITBANG) of MoF was the implementing agency, and the Forest Research Institute in Samarinda carried out the project. A number of special study reports were produced by short term consultants. ${ }^{6}$ The study was divided into two parts:

Part 1 - The fire, the effects, the damage, and the technical solutions;

Part 2 - Necessary steps for forest rehabilitation.

\section{Objectives and terms of reference:}

- to conduct a detailed examination of the present condition of the forest area in East Kalimantan seriously affected by drought and fire in 198283; to study the effects of the drought and fire; to estimate the resulting damage;

- to classify the area according to possibilities for rehabilitation (particularly the productive hardwood forest, and to map these themes);

- to draw up an action plan for the rehabilitation of the burnt area taking into consideration the results of existing research;

- to assist in setting up a demonstration project illustrating the methods now available for rehabilitation; and

- to draw up a detailed design and specification of a pilot project for the rehabilitation of the various classes.

\section{Recommendations for fire prevention and control in East Kalimantan:}

- introduce community forestry;

- institute a fire control system;

- organise a fire control service (establish a fire fighting school in Samarinda);

- develop an early warning system, including fire risk mapping;
- take preventive action (awareness, fire breaks, instruction in fire fighting for local people); and establish an emergency mobile fire fighting force.

\section{Japan}

3a. Japan Forest Technical Association (JAFTA)

Study on Development of Technology for Rehabilitation of Forest Devastated by Fire 11-30 September 1993

Objectives: Use remote sensing to assess the extent of devastation by fire in tropical forest, and to establish a method for preparing a disaster rehabilitation plan based on the assessment.

3b. JICA

\section{Long-term Expertise on Forest Fire Prevention}

7 April 1993-6 April 1995

Expert: Mr. Sato

Activities: Conduct field survey and recommend forest fire prevention plans; prepare awareness materials; provide support to integrated fire management in Indonesia and make proposal to ITTO.

${ }^{6}$ Chandradewana Boer 1989 Effects of the forest fire 1982-83 in East Kalimantan on wildlife. FR-Report No. 7; Sarwono 1989 Effects of the forest fires 1982-83 in East Kalimantan on fishery and hydrology. FR-Report No. 8; Mayer, J.H. 1989 Socioeconomic aspects of the forest fire 1982-83 and the relation of local communities towards forestry and forest management in East Kalimantan. FR-report No. 9; Sakuntaladewi, N. and Amblani, M. 1989 Socioeconomic aspects of the forest fire 1982-83 and the relation of transmigrants towards forestry and forest management in East Kalimantan. FRReport No.11; Panzer, K, 1989. Utilization of burnt and degraded forest land in East Kalimantan. FR-Report No.12. 


\section{UNDP}

Preparatory Phase National Forest Fire Management Capacity (proposal)

One year, starting early 1994, implementing some of those activities mentioned in the FAO/UNDP Mission Report (refer to 'Missions: No.6').

UNDP (US\$ 346 000), GOI (Rp. 101900000 in kind).

\subsection{Workshops and Seminars}

\section{Canada}

\section{Seminar on Forest Fire Suppression}

5 May (Medan), 9 May (Samarinda), 11 May (Jakarta) 1992

Conclusions and recommendations: Integrated approach to forest fire management; fixed organisation with clear coordination and responsibility; establishment of early warning system; fire suppression training; extension programmes; coordination between donor countries to support forest fire control.

\section{Finland (FINNIDA)}

\section{Seminar on Forest Fire Control Indonesia}

21 August-11 September 1992 in Balikpapan, Banjarbaru (South Kalimantan), Bali and Jakarta. Target group: 20 forestry officers working for the government or wood industries.

Objective: After the course, participants were to be able to plan, organise and implement fire prevention; demonstrate use of equipment; fight forest fires more efficiently; know most important activities in fire prevention, detection and suppression.

\subsection{Missions}

\section{Australia}

Report Assessment Team on Forest and Forest-related Fires in Indonesia 1991

18-25 October 1991
Recommendations and conclusions: Reducing smoke pollution; improving fire management of shifting cultivation fires, crop residue and weed disposal fires, plantation and concession fires, coal seam fires; training; visited Bukit Soeharto and areas north and south of Balikpapan, East Kalimantan.

\section{European Commission \\ EC Forestry Mission, Fire Protection}

26 June-3 July 1992

Conclusions: Visited North and South Sumatra to select possible sites for implementation of model; set up fire fighting capability with equipment, training, NOAA satellite receiver in selected locations.

\section{FAO}

3a. Assistance in Forest Fire Prevention and Control

21 July - 13 October 1986 (TCP/INS/1513 (1))

Conclusions and recommendations: Strengthen PHPA (Forest Fire Sub-Directorate), selection of East Java as a demonstration province.

- Project Proposal 1 - Strengthening Institutional and Technical Capabilities in Forest Fire Management, donor inputs US\$ 375 000, promotion, coordination and assessment of integrated forest fire management at national level, establishment of central database on wildfire damages, implementation of fire weather forecasting.

- Project Proposal 2 - Integrated Forest Fire Management, North Sumatra, donor inputs US\$ 1760000 , increased and sustained production of forest product, improved watershed management, rehabilitation of critical lands.

\section{3b. Emergency Assistance to Forest Fire Management}

1-10 December 1991 (TCP/INS/155)

Conclusions: Immediate execution of short-term fire management enhancement programme; 
rehabilitation of most severely burnt areas; GOI preparation of fire prevention plan for 1992; FAO approval and staffing of a national fire management project; GOI encouragement to all HPHs to increase investment in fire protection.

\section{International Tropical Timber Organization (ITTO)}

4a. Consultative Visit to Indonesia with regard to ITTO Activity on the Protection of Tropical Forests against Fire

\section{January-7 February 1992}

Conclusions: Great diversity in causes of fire requires different fire management solutions; management of smoke problem warrants special attention as it crosses international boundaries; development and coordination of funding at all levels to strengthen fire management activities; implementation of an operational fire early warning system; priority given to improving fire management capabilities in Sumatra and Kalimantan.

4b. Establishment of a Demonstration Plot for Rehabilitation of Forest Affected by Fire in East Kalimantan

June 1993

Report for review mission.

Comments: No further information available.

\section{Japan}

5a. JICA Fact-finding Mission to East Kalimantan and South Sulawesi

18 November-1 December 1991

\section{Conclusions:}

East Kalimantan - Most fires occurred AugustSeptember; according to a report by MoF, total burnt area was 3750 ha; major causes of fire were slash-and-burn agriculture, discarded cigarettes and burning crops on coal seams; fire fighting methods were observed (fire breaks, water, soil); fire fighting activities were observed in concessions and farmers' fields; fire fighters consisted of army personnel, farmers and concession workers; burnt forest was of a secondary type with alang-alang grasses, primary forest exhibited a high resistance to fires; forest fires were mainly surface fires; 35 coal seam fires in Bukit Soeharto.

South Sulawesi - MoF estimate of 1650 ha in 1991; fire fighting carried out mainly by local farmers in vicinity of forest areas; burnt vegetation consisted of planted forests of merkusi pine, eucalyptus, acacia and albizzia, and their resistance to fire was low.

\section{5b. JICA Provision of Forest Fire Fighting Equipment}

February 1992

Equipment: Pumps, safety gear for fire crews, hand tools.

Placement: Way Kambas NP, Lampung; Kanwil, East Kalimantan, South Sulawesi and East Sulawesi; PT Inhutani I, South Sulawesi.

\section{United Nations Development Programme (UNDP)/FAO}

\section{Forest Fire Management in Indonesia Formulation Mission}

26 April-25 May 1993 (TCP/INS/91/008)

Objectives: Review government policies; assess institutional and human resource capacity; assess scope of assistance provided by donors; review coordination between government agencies and donor projects; identify scope of UNDP technical assistance.

Output: Project proposal titled 'National Forest Fire Management Capacity'

- cohesive national policy defined to guide forest fire management activities;

- organisational structure of central forest fire management;

- national forest fire prevention education programme; 
- national guidelines for regulation of agricultural burning, logging and other land use practices that cause fires;

- guidelines for management of combustible fuels;

- establishment of fire incidence monitoring and reporting system;

- national guidelines for forest fire suppression;

- development of forest fire danger rating system;

- identification of priorities for capacity building at provincial and unit level; and

- development of forest fire management plans for two high priority provinces.

\section{USA}

US Fire Assessment Team on Forest Related Fire in Indonesia

21 October -7 November 1991

Recommendations for 1992:

- implement recommendations from reports, missions and projects since 1982-83 fires;

- establish fire management specialist staff position at USAID in Jakarta for 2 years to assist GOI and establish demonstration projects;

- initiate phase of the 1988 training in provinces at highest risk of fire;

- initiate fire suppression programme;

- explore with GOI establishment of a burning period for agricultural and concession clearing based on predicted weather conditions for individual provinces;

- expedite development of central reporting system on planned, controlled and uncontrolled burning for agriculture and forestry land; and

- initiate fire danger system to predict fire risk conditions; institute fire prevention programme.

\subsection{Training Courses}

\section{USA}

1a. USA/US Agency for International

Development (USAID)

Training in Forest Fire Prevention, Detection and Mitigation

1-13 August

Jakarta and Sukabumi (West Java)

Content: Comprehensive training on forest fires given by US and Indonesian instructors

19 October-16 November 1989

Content: Short-term training course given in the US to three professionals from South and East Kalimantan.

1b. USA/USAID

Training in Forest Fire Prevention, Control and Mitigation

29 July-4 August 1992

Pematang Siantar (North Sumatra) and Madiun (East Java)

Participants: 124 from 22 provinces; 6 US instructors

1c. USA/USAID

Training in Forest Fire Prevention, Control and Mitigation

20-29 July 1993

Ujung Pandang (South Sulawesi) and Pekanbaru (Riau).

Participants: 90 from government, NGOs and the private sector; 8 US instructors (content similar to that of 1992 course). 


\section{Ongoing Fire Projects}

After the forest and land fires of 1991 that resulted in economic losses and prolonged smoke haze over Southeast Asia, the GOI resolved to seek international advice and assistance. In June 1992, GTZ and BAPPENAS held a 2-day international workshop in Bandung, West Java, on long-term integrated fire management. This workshop identified the main problem as the lack of an operational fire management system in Indonesia

The conclusions of the workshop provided the impetus for a number of long-term fire projects. There are currently three major ongoing donorassisted forest fire management programmes in Indonesia: 1) EU Forest Fire Prevention and Control Project; 2) GTZ Integrated Forest Fire Management Project; and 3) JICA Forest Fire Prevention Management Project. All of these began before the 1997 fires. In addition, the Indonesia-UK Tropical Forest Management Programme is a British forestry programme that includes some fire activities and should be mentioned. This chapter gives an overview of the projects, including objectives, main activities and conclusions.

\subsection{EU-Forest Fire Prevention and Control Project (FFPCP)}

$\begin{array}{ll}\begin{array}{l}\text { Donor/Agency: } \\ \text { Executing Agency }\end{array} & \text { European Union } \\ \text { (Indonesia): } & \text { PHPA, Ministry of Forestry } \\ \text { Project type: } & \text { Multilateral } \\ \text { Budget grant: } & \text { US\$ 4,879,759 (ECU } \\ & 4,050,200 \text { using exchange } \\ & \text { rate on 13/8/96) } \\ \text { Country budget: } & \text { US\$ 628,193 (ECU 521,400) } \\ \text { Total budget: } & \text { US\$ 5,507,952 } \\ \text { Consultants: } & \text { Natural Resources Institute } \\ & \text { (NRI), BCEOM, CIRAD } \\ & \text { Foret and SCOT Conseil }\end{array}$

Name of project: Forest Fire Prevention and Control Project (FFPCP)

Regions/Provinces: South Sumatra Province

Project office: $\quad$ FFPCP, PO Box 1299, Palembang 30000, South Sumatra. Tel: 0711410955. Fax: 0711417137 E-mail: rodbowen@mdp.co.id Web site: http:// www.mdp.co.id/ffpcp Project leader: Dr Roderick Bowen Time frame: $\quad$ April 1995 - May 1999 (Phase II is under discussion).

\section{FFPCP Description}

The project has its origins in the 1992 Bandung Conference which recommended the development of an integrated forest fire management strategy for Indonesia. FFPCP commenced in March 1995 as a component of an Indonesia Forest Sector Support Programme (IFSSP) which also included a Forest Inventory and Monitoring Project (FIMP) and a Radio Communications Project. Within the IFSSP's goal, To furnish support, guidance and technical capability to the rational and sustainable management of the country's forest resources, the specific purpose of the FFPCP is To develop integrated systems of forest fire prevention and control involving local government, community and commercial interests in South Sumatra Province. Target groups include:

- Ministry of Forestry, Directorate General Forest Protection and Nature Conservation (PHPA) and Kanwil and Dinas Kehutanan dan Perkebunan in South Sumatra Province;

- rural population; 
- holders of forest concessions and large and small scale tree plantations.

\section{Rural Development Component}

During early phases of the project, studies were undertaken to identify the direct and indirect causes of forest fires in South Sumatra. As a result of these studies, several socio-economic aspects of relevance to fire prevention have been examined by the project. These included:

- Alternative livelihood systems for village-based communities, including micro-projects designed to generate additional and/or alternative income; and

- Land preparation techniques that do not rely solely on the use of fire.

Current activities are directed towards an understanding of the underlying causes of the serious fires which periodically affect South Sumatra Province (as well as other areas in Indonesia e.g. the 1997 fire crisis). Land use policy and implementation procedures are being examined with a view to suggesting ways in which a more integrated approach to planning could reduce the occurrence of vegetation fires.

Several specialist inputs are planned to assist with the above activities; in particular, to elucidate government land-use policy, planning and implementation procedures, at local/provincial level, through the recruitment of an institutional impact analyst, and specialists in administrative and customary law.

In collaboration with local NGOs, the project has been promoting school campaigns designed to raise children's awareness of the danger of vegetation fires.

\section{Fire Management Component}

The principal objective of the fire management activities is to implement a fire prevention and control plan, developed by the project in liaison with Kanwil Kehutanan dan Perkebunan, Palembang, within five priority (high fire risk) Districts of South Sumatra. These are OKI, MUBA,
Bangka, Muara Enim and Lahat. The plan will include the provision of e-mail facilities in each District at the Kantor Cabang Dinas Kehutanan dan Perkebunan office so that information on NOAA detected fires and fire danger warnings can be transmitted in a timely manner.

Key activities have involved training in new concepts in fire fighting and personnel security, analysis of forest fires, tactics of anticipation, the pyramid of command and the first aid treatment of burns. A series of booklets has been prepared to summarise the essential elements of the training courses. Fire fighting equipment is being procured through the project to enhance the existing and planned fire prevention and control organisation in South Sumatra.

A web site describing project activities and hot spot/fire danger information can be found at http:/ /www.mdp.co.id/ffpcp.

\section{NOAA Fire Detection Component}

The main function of the NOAA satellite receiving and processing system at Palembang is the identification of fire occurrences and their locations in southern Sumatra followed by the expeditious transmission of this information to those government organisations most directly concerned with protection against vegetation fires. The system has been operating continuously since January 1996. The principal recipients of the fire data are Dinas and Kanwil Kehutanan dan Perkebunan in the provinces of South Sumatra, Lampung, Bengkulu, Jambi and Riau. Procedures have been developed by the project to plan, capture, evaluate, process and archive NOAA data. Integration of this data with a Geographic Information System allows the generation of fire maps, vegetation assessments and other statistics relating to the varied biophysical conditions in southern Sumatra.

\section{Research on fire risk and fire danger assessment}

As part of a 3-year (1995-98) adaptive research project supported by the DFID Forest Research 
Programme (FRP), a research project on fire risk assessment was established between IFSSP and NRI. The overall aim of the NRI research was to provide better tools to help fire managers make more informed decisions with respect to fire prevention and control. The research involved the development of new methodologies to detect fires with NOAA-AVHRR and the creation of userfriendly tools for integrating fire data into a GIS.

The NRI-IFSSP research project ran from September-December 1997 and consisted of the following phases (FFPCP 1998):

Phase 1 - Production of fire risk maps developed by integrating historical fire data (hot spots 199697) into a GIS.

Phase 2 -Development of new methodologies for the estimation of fire danger rating - NOAAAVHRR imagery was analysed to produce a fuel status in terms of moisture (fire danger rating). The methodology used vegetation indices (Relative Greenness Index) and land surface temperature derived from AVHRR and linked them with the Soil Dryness Index (daily maximum air temperature and evapo-transpiration measurements).

Phase 3 - Development of a new methodology for the integration of fire risk maps and fire danger to provide a first estimation of fire risk occurrenceThe results cannot yet be used operationally because research is still required to quantify accuracy. In the future additional factors such as weather danger (wind), elevation and slope, fuel type and fuel load should also be taken into consideration.

\subsection{GTZ -Integrated Forest Fire Management Project (IFFM)}

$\begin{array}{ll}\text { Donor/Agency: } & \text { Federal Ministry for } \\ & \text { Economic Cooperation and } \\ & \text { Development (Germany) } \\ \text { Overall Charge: } & \text { German Agency for } \\ & \text { Technical Cooperation } \\ & \text { (GTZ) }\end{array}$

Executing Agency

(Indonesia):

Ministry of Forestry (PHPA)

\section{Implementing} Agencies:

\section{Project Type: \\ Budget Grant:}

Kanwil Kehutanan (local policy making)

Dinas Kehutanan (local field implementation)

Bilateral

Technical Cooperation (GTZ):

Phase I (1994-1997): DM 4.5 million (GTZ)

Phase II (1997-2000): DM 5.0 million (GTZ)

Phase III (2000- ): to be determined

Financial Cooperation (KfW):

during Phase II/III: $\quad$ DM 10.0 million (KfW)

(procurement of fire equipment)

\section{Country Grant:}

Operational budget and facilities

Consultants: DFS and GITEC (for KfW)

Regions/Provinces: East Kalimantan

Project Office:

Jl. Kesuma Bangsa/

Harmonika

Kotak Pos 826 (KT), Samarinda 75001, East Kalimantan. Tel: 054132625 , Fax: 054133519 E-mail: iffmfire@iffm.on.id Website: http://www.iffm.or.id Team Leader: Ludwig Schindler Community Fire Mgmt: Hartmut Abberger NOAA Specialist: Anja Hoffmann

Time frame: Phase I (April 1994 April 1997) Phase II (April 1997 April 2000)

Phase III to be determined

\section{IFFM project description}

During Phase I (1994-1997) fire protection, training needs, suitable equipment, necessary fire intelligence, institutional and structural support 
were evaluated and determined for the Bukit Soeharto pilot area. Cooperation with relevant government agencies and timber concessionaires has been ongoing. At the village level, socioeconomic studies have been carried out to elaborate a concept of community-based fire management and to organise volunteer fire response crews. Fire prevention material has been produced to raise public awareness.

In the second and third phases, the scheme applied in Bukit Soeharto will be replicated in other areas of East Kalimantan. Local fire centres in all the 10 Cabang Dinas Kehutanan as well as Kutai and Kayan Mentarang National Parks will be established and equipped, and personnel at all levels will be trained to prevent and respond to wildfires. These local fire centres will form the core of a fire management system for the province. They will report to the provincial fire centre in Samarinda, which will coordinate fire management activities in East Kalimantan. The provincial fire centre will collect information from the local offices, providing fire intelligence (fire hot spot locations, fire danger rating, radio communications) and coordinate the sharing of equipment and fire-fighting personnel between fire stations.

The fire management system introduced by IFFM for the province of East Kalimantan further includes:

- an Early Warning System based on El Niño predictions, a Fire Danger Rating System and actual satellite monitoring by NOAA AVHRR imagery;

- a community-based fire management programme that is likely to extend to all areas, including village awareness campaigns, fire prevention and suppression training, provision of basic tools for villagers, set-up of village fire response crews and school campaigns. Leaflets, Si Pongi ${ }^{7}$ comic books, stickers, posters, hats, shirts and other items are used to spread the prevention message;

- $\mathrm{MSc} / \mathrm{PhD}$ scholarships in Fire Management for Indonesian university lecturers and forestry personnel at universities in Australia and USA;
- study tours and training of fire fighters (training of trainers) in USA and Australia;

- local training in fire behaviour and fire suppression for all relevant groups (forest guards, concessionaires, Armed Forces, villagers, boy scouts);

- production of training guidelines and books for different levels and fire management guidelines for concession companies to be prepared in cooperation with the EU-FFPCP;

- the set up of a comprehensive FIRE-GIS for East Kalimantan in the Provincial Fire Centre, Samarinda. The GIS includes NOAA and ERS radar satellite data, base maps, vegetation cover maps, burnt scar maps, actual fire danger and hotspot information, infrastructure, transmigration sites and many more themes. In response to the lack of accurate information regarding the area burnt in 1998, IFFM will produce a precise satellite-based assessment of the affected area. NOAA AVHRR and ERS radar imagery will be used; and

- cooperation with two partner forestry concessions in East Kalimantan in conjunction with the GTZ Sustainable Forestry Management Project (SFMP).

\section{Response to the 1997-98 fires}

As a response to the escalating fire situation in 1997, the German Government provided additional funding for IFFM (DM 0.5 million), which was mainly used to set up a tool cache for 400 fire fighters in Samarinda and hand out equipment wherever needed to fight the blaze.

IFFM began training the Indonesian Armed Forces in October 1997, and in February and March 1998 conducted one training session per week in 'Basic Fire Behaviour and Suppression' for all the

\footnotetext{
${ }^{7} \mathrm{Si}$ Pongi is the Indonesian fire fighting mascot equivalent of Smokey Bear in the USA. Instead of a bear an orang utan is used.
} 
Territorial Commands of Kalimantan and Sumatra. The trainees were officers in charge of training soldiers and commanding fire suppression efforts. At the same time prevention campaigns in villages were intensified and TV spots for fire prevention were prepared in cooperation with MoFEC, WWF, EU and JICA and broadcast on national television.

Finally, at the policy level, IFFM has intensively tried to highlight the underlying causes and the important problems concerning wildland and conversion fires with its partner organisations, at meetings and by means of a massive media campaign.

\subsection{JICA - Forest Fire Prevention and Management Project (FFPMP)}

Donor/Agency: Japanese International

Cooperation Agency (JICA)

Executing

Agency:

Project Type: Bilateral

Budget Grant: US\$ 8296250 (exchange rate 16/9/96)

\section{Regions/}

Provinces: Central Level (Bogor), Rantau Rasau Subdistrict, Jambi, and Nanga Pinoh Subdistrict, West Kalimantan

Project Office: Head Office, Direktorat

Perlindungan Hutan, Ditjen PHPA

Jl. Ir. H. Juanda No. 100,

Bogor 16100

Tel: 0251323972

Personnel: $\quad$ Five JICA experts and Indonesian counterparts Team Leader: Miyakawa Hideki; EWS Specialist: Ueda Tomoyuki; Jambi Site:

Masahiro Otsuka

Time frame: April 1996-April 2001 (5 years)

\section{FFPMP project description}

The overall goal of the project is to prevent forest devastation and environmental disturbances caused by wildfires and smoke. The project aims to strengthen the capability of the MoF at the central level, in Jakarta and Bogor, to deal quickly with forest fires and also to improve prevention and initial suppression at the local level.

The field site in Jambi is located in a lowland peat swamp area in close proximity to Berbak National Park. The site in West Kalimantan is located in a hilly area in the Sintang Regency.

\section{Project objectives}

As described in a project brochure, these will be achieved through the following activities:

\section{Early warning and detection system}

Identification of forest fire-prone areas and detection of fire hot spots and smoke using HIMAWARI and NOAA satellite imagery. In early 1997, a satellite image receiving station was set up in the Directorate of Forest Protection in Bogor. Two systems are in use. One receives hourly meteorological images from the Japanese HIMAWARI satellite, and the other is a Britishmade NOAA-AVHRR receiver similar to the model used by the EU FFPCP in Palembang.

The HIMAWARI imagery covers all of Indonesia, Australia and Asia; the spatial resolution is more than the $1 \mathrm{~km} \times 1 \mathrm{~km}$ of AVHRR. Imagery from HIMAWARI is used mainly for monitoring haze and smoke and not for the identification of fire hot spots. The AVHRR imagery, which is received twice daily, is automatically processed to produce hot spot maps for Kalimantan and Sumatra, and occasionally Maluku and Sulawesi.

Visibility permitting, daily fire hot spot maps were produced by the JICA/PHPA system during the 1997-98 fires. This information was relayed directly to the Minister of Forestry and the provincial forestry offices. The hot spot maps can be viewed on the Ministry of Forestry Web site; (http://mofrinet.cbn.net.id/). 
During November 1997, field checking of fire hot spot maps was carried out in the province of Lampung from a helicopter. In hilly terrain and certain vegetation types, it was found that there was a poor comparison between recorded hot spots and burn scars on the ground. A number of other projects ${ }^{8}$ have also found a poor comparison between hot spots identified using AVHRR and actual hot spots on the ground. Appendix 1 describes some of the problems encountered when analysing hot spots.

Planned activities for 1997-98 include:

- development of image processing techniques for HIMAWARI and NOAA imagery and hot spot detection based on the field results of 1997;

- production of a forest fire base map using weather, land cover and land cover parameters; and

- field application of the Forest Fire Rating System.

\section{Extension and training}

Extension and education concerning forest fire prevention and training in initial suppression will be given to local communities (at the sites in Jambi and West Kalimantan) and local forestry staff. The extension programme consists of films, pamphlets and discussions. The total number of village participants in the first year was approximately 2700. In 1997, a theoretical and practical training programme in initial suppression techniques was given to forestry staff in West Kalimantan.

Planned activities for 1997-98 include: improvement of extension materials, extension programmes in at least 20 communities in each of the project sites;

- development of an evaluation method for the extension activities; and

- a survey of forest fire characteristics in peat swamp forest at the Jambi site.

\section{Participatory methods}

Forest management techniques that are effective for forest fire prevention along with greenbelt establishment trials will be introduced to local communities in the project sites. During 1996-97, a preliminary survey through interviews was conducted on the socioeconomic and cultural aspects of the communities in the Jambi project site.

Planned activities for 1997-98 include:

- a survey of the socioeconomic and cultural aspects of the local communities at the West Kalimantan site;

- implementation of a participatory fire management approach at the Jambi site; and

- preparation for establishment of a greenbelt establishment at the Jambi site.

Otsuka (1997) suggested possible participatory approaches to forest fire prevention at the Jambi site. These included land use intensification and the establishment of greenbelts and fuel breaks. He also suggested surveys of biophysical and socioeconomic dimensions of the fire problem, fire histories and fire prone areas, customary land management and control, land tenure status and conflicts, community self-help activities and government assistance and communities' response.

\subsection{Indonesia-UK Tropical Forest Management Programme (ITFMP)}
Donor/Agency:
Department for
International Development
(DFID, formerly ODA)
Executing Agency: Ministry of Forestry
Budget: 1992-96 (£ 10000000 ); no data available for budget beyond 1997; also contribution from $\mathrm{MoF}$

\section{Project Type: Consultants:} Bilateral grant

${ }^{8}$ Personal comunication, Chris Legg (EU-FIMP), 27 January 1998, and Martin Hardjono (WWF-ID), 30 January 1998. 


$\begin{array}{ll}\text { Name of Project: } & \text { ITFMP consists of five } \\ & \text { interlinked projects; two } \\ & \text { contain activities related to } \\ & \text { forest fires: } \\ & \text { Project 2: Provincial Forest } \\ & \text { Management } \\ & \text { Project 5: Community Based } \\ & \text { Conservation Management } \\ & \text { Kalimantan, Riau and } \\ \text { Regions/Provinces: } & \text { Central Kalimantan, West } \\ & \text { Jambi } \\ \text { Project Office: } & \text { Manggala Wanabakti } \\ & \text { Block VII, Floor 6 } \\ & \text { Jalan Gatot Subroto, } \\ & \text { Jakarta 12720 } \\ & \text { Tel: 021 572 0225 } \\ & \text { Dr Alastair Fraser, } \\ \text { Programme Coordinator } \\ \text { Time frame: } & \text { November 1991-June 1997 } \\ & \text { (Project 1) } \\ & \text { April 1992-June 1997 } \\ & \text { (Projects 3, 4, 5) } \\ & \text { April 1993-late-1999 } \\ \text { (Project 2) }\end{array}$

\section{Programme description}

The programme consists of five linked projects that share the same goal of promoting sustainable management of Indonesia's remaining lowland forests. Four of the projects address timber production and the fifth concerns the management of conservation forest areas.

Project 1: Senior Management Advisory Team (SMAT) based in Jakarta

Project 2: Provincial Forest Management (Riau and Jambi provinces in Sumatra; Central Kalimantan)

Project 3: Research (Central Kalimantan)

Project 4: Training (Riau, East Kalimantan and Bogor)

Project 5: Conservation (West Kalimantan and Bogor)

\section{Project 2 - Provincial Forest Management (activities related to fires)}

A clear need for timely data for vegetation and fire monitoring over large areas was identified, and the potential for NOAA imagery was clearly recognised by the ITFMP. Therefore, it was decided that a system for local reception of NOAA data should be developed as part of the programme.

On this basis, the hardware, software, and training requirements were assessed and a decision was made to establish a NOAA receiving station in Kalimantan with Project 2 (Provincial Forest Management) under the UK Natural Resources Institute's LARST ${ }^{9}$ programme. In September 1993 an NRI consultant installed a receiving station for NOAA AVHRR at the provincial forestry office in Palangkaraya, Central Kalimantan. Most of the initial work concentrated on images for Kalimantan and Sumatra. Particular attention was given to training of local counterpart staff in the use of the technology, assessment of the institutional aspects of installing the technology, and awareness building both locally and nationally about the benefits of such technology.

The system became fully operational in early 1994. In April 1994, a full-time expatriate GIS and remote sensing specialist was assigned to provide training and supervise activities. Imagery was collected intermittently over the 1994 fire season. Hot spot data were distributed to the local forestry offices, the governor, the GTZ project in East Kalimantan, and the MoF in Jakarta.

\footnotetext{
${ }^{9}$ Under the Local Applications of Remote Sensing Techniques (LARST) Programme, and in conjunction with Bradford University Research Limited (BURL), the NRI has developed systems for local reception of satellite data and product generation. These systems are designed to be low-cost and easy to use, allowing users to have direct access to free data from environmental satellites, including NOAA and METEOSAT. Specially developed software then permits the user to interpret the data on-site using PCs. The total cost of the system is less than US\$ 60000 (1995 prices).
} 


\section{Project 5 - Community-based Conservation Management (activities related to fires)}

The Conservation Project aimed primarily at strengthening the institution of PHPA and consists of two components: 1) community-based participatory management of DSWR in West Kalimantan; and 2) improved management of DSWR through the use of remote sensing and GIS.

The Danau Sentarum Wildlife Reserve covers an area of 132000 ha in the flood plain of the upper Kapuas River in West Kalimantan. Some 700 km upstream from the mouth of the Kapuas River, the freshwater lakes and flooded forests of this remote area are a unique environment. Fire is an all important factor controlling vegetation patterns in the reserve (Giesen 1996). Through interpretation of remotely sensed imagery and field checking, it is estimated that up to $26 \%$ (27000 ha) of the vegetated area of the reserve has burned at some time in the past 25 years (Dennis in preparation). Time series analysis mapped the change in burnt area and degree of regeneration between 1973 and 1994 in three village territories in the reserve (Dennis et al. 1998).

In addition to the remote sensing and mapping of the extent of fires, and the studies of vegetation types in burnt sites Giesen (1996), Luttrell (1994) studied the underlying causes of the fires. In this study, the cause of the fires was attributed by local people to neglect (cigarettes, campfires, fish-drying fires) or jealousy over natural resources claimed by villages. Often the blame would be put on another ethnic group. Giesen (1987) suggested that burning of vegetation surrounding ponds or lakes increased the area of open water, so that more fishing nets could then be placed. One possibility quoted by Luttrell (1994) is that fires are ignited to facilitate the capture of valuable ornamental fish. Burning creates shallow, open waters at the forest edge where the fish can be lured by lamplight and scooped up by fishermen wading in the water. Most people interviewed by Luttrell (1994) stated that the fires have a strong negative impact on their livelihoods.

With almost $26 \%$ of the reserve's forests burned, the project considered fires a serious problem for reserve management that should be immediately addressed. A programme dealing with fire awareness and village fire monitoring systems was set up. In addition, studies of the traditional laws were carried out to assess these systems as a means of imposing sanctions for burning. Since the project finished in 1997, Wetlands International (WI) has maintained a presence in the reserve in addition to the reserve guards and staff. Fires are still monitored by WI staff and reserve guards. 


\section{Fire Projects in the Aftermath of the 1997 Fires}

Although fires in 1987, 1991 and 1994 were more severe than average, the devastation of the drought and fires of 1982-83 were not rivalled until 199798. The latest fires have fuelled a new generation of reports, seminars, fire fighting endeavours, and short- and long-term projects. This chapter discribes these new fire projects and those proposed.

\subsection{EU Fire Response Group (EUFREG)}

Donor/Agency: European Union

Executing

Agency:

Budget:

Consultants: Members of existing EU forestry projects

\section{Regions/}

Provinces:

Kalimantan and Sumatra

Project Office: Forest Liaison Bureau, Manggala Wanabakti Building, Block VII, Floor 6, Jl. Gatot Subroto, Jakarta 12720. Tel 0215720194 ,

Fax 0215720219

Director: John Keating

FIMP Office, Manggala Wanabakti Building, Block IV, Floor 5, Jl. Gatot Subroto, Jakarta 10270. Tel 0215720211

Contact: Chris Legg, Yves Laumonier

Time frame: October 1997-May 1998

\section{Description}

EUFREG was under the chairmanship of the Forest Liaison Bureau (formed 2 October 1997). A description of EUFREG is available in EU-FLB (1997) and Trigg (1997), and the following task descriptions are extracted from these documents.

\section{Tasks:}

- collate all available information and channel it to the EC-Representation for dissemination to Brussels and to EU member state embassies;

- produce regular info-flashes on the evolving situation;

- coordinate with GOI;

- liaise with other donors;

- act as a focal point between GOI and EU member states;

- assess need for EU aid as situation evolves;

- coordinate procurement and distribution of aid; and

- provide advice on the coordination of EU member states' bilateral assistance.

\section{Fire monitoring}

EUFREG mobilised experts from existing EU projects to attempt a rapid estimation of the area affected. The group was requested to comment on the distribution, area, and nature of the fires; to make recommendations for a more detailed study; and to suggest ways in which the existing network of fire monitoring systems in Indonesia could be improved. For this purpose, remotely sensed data were obtained and interpreted using the GIS of the EU Forest Inventory and Monitoring Project (FIMP), and existing GISs within MoF. The general distribution of fires during September was analysed 
and an attempt was made to measure the extent of areas burned in South Sumatra, as well as determine types of vegetation affected.

Data used for the assessment consisted of:

- hot spots from the EU FFPCP NOAA station in Palembang and the JICA/PHPA receiving station in Bogor for Sumatra and Kalimantan;

- hot spots from the GTZ station in Samarinda for Kalimantan and Sulawesi;

- SPOT digital quicklooks from the Centre for Remote Image Sensing and Processing (CRISP) at the National University of Singapore; the images can be downloaded from the Web site (http:// www.crisp.nus.edu.sg);

- Landsat TM digital quicklooks from the Australian Centre for Remote Sensing (ACRES) for Irian Jaya; and

- Landsat TM paper quicklooks from LAPAN for Sumatra and Kalimantan; Along-Track scanning Radiometer (ATSR-2) images from the ERS-2 satellite of the European Space Agency (ESA) were downloaded from the ESA Earth Watching Web Page (http://earth1.esrin.esa.it:8080/ew) for comparison with AVHRR data; maps of wildfire occurrence from the US Forest Web page(http:// www.fs.fed.us/eng/indofire/).

\section{Results}

Southern Sumatra (Lampung and South Sumatra) were the focus of Phase 1. Based on rapid estimation, total burnt area in South Sumatra was estimated at about 1 million ha; a crude extrapolation from South Sumatra to the whole of Indonesia suggested a total in excess of 2 million ha (forest and non-forest). Primary forest appeared to be relatively unaffected. The total area of forest (disturbed and/or logged primary forest and dense secondary) that burned in the whole of Indonesia was probably in the range of $150000-300000$ ha (EU-FLB 1997).

\section{Phase 2}

Phase II expanded the burnt area assessment from the provinces of Lampung and South Sumatra to

cover all of southern Kalimantan and the remainder of the fire-affected parts of Sumatra. The total burnt area during the 1997 fires was estimated to be in excess of 2.5 million hectares, approximately equally divided between southern Sumatra and southern Kalimantan (EUFREG 1998). Technical problems prevented more precise assessment of the burnt area and the proportion of land cover and forest types affected by the fire.

\subsection{World Wide Fund for Nature- Indonesia (WWF-ID) - Analysis of the Causes and Impacts of Forest Fires and Haze}

Funding:

\section{Executing \\ Agency: \\ Budget: \\ Partners:}

\section{Regions/}

Provinces:
Project Office:

WWF-Netherlands, WWFSwitzerland, WWF-UK and the Body Shop

$$
\begin{aligned}
& \text { WWF - Indonesia } \\
& \text { US\$ } 546590 \\
& \text { Economy and Environment } \\
& \text { Program for SE Asia (EEPSEA); } \\
& \text { IDRISI Project; George } \\
& \text { Washington University (GWU); } \\
& \text { BAPEDAL; PHPA; World } \\
& \text { Resources Institute (WRI); } \\
& \text { TELAPAK; WALHI; IFFM-GTZ. }
\end{aligned}
$$

Southeast Asia (economic impacts), Indonesia (policy), Kalimantan (remote sensing/GIS, causes, biological impacts)

Timeframe: October 1997-September 1998. A Phase 2 started in October 1998.

WWF-Indonesia, Jl. Kramat Pela No.3, Gandaria Utara Jakarta Selatan 12140. Tel: 021 7203095, Fax: 0217395907 Project Supervisor: Timothy Jessup e-mail: tjessup@wwfnet.id Web site: http//www.wwf.or.id 


\section{WWF-ID project description}

As early as September 1997 WWF-Indonesia was already providing support to the Ministry of Environment's Fire Command Centre at BAPEDAL through GIS technical expertise in producing the daily hot spot maps. WWFNetherlands also provided funding for the compilation of a bibliography on forest fires in Indonesia (Meijaard and Dennis 1997) to assist those investigating the current fires. The reference list from this bibliography is shown in Appendix 4. In December 1997, WWF International issued a report entitled 'The year the world caught fire' (WWF 1997) which described how the fires in Indonesia fit into the larger global picture of fires.

The project is focussing on the causes of the 1997-98 fires and their impacts through the following activities:

- background assessment of the forest fires and their causes;

- economic assessment in cooperation with EEPSEA;

- policy assessment: based on the data gathered, a policy analysis will be conducted and policy recommendations developed;

- biological assessment of fire impacts on plants, animals and ecosystems;

- remote sensing/GIS assessment of fire distribution and of area burnt in cooperation with George Washington University and the IDRISI Project at Clark University;

- social assessment of causes and impacts on health and livelihoods;

- communication of results through press releases, workshops and reports;

- training of park rangers from Kutai NP and Tanjung NP in ecological monitoring, technical assistance in fire monitoring using GIS provided to BAPEDAL; and

- GIS training to be offered to NGOs, BAPEDAL, and others.

\section{Economic assessment}

Commencing in October 1997, WWF-ID and EEPSEA undertook a study to assess the economic cost of the damage caused by the 1997 fires and haze. EEPSEA and WWF-ID staff and academic researchers in Indonesia, Malaysia and Singapore, with methodological advice from international experts conducted the study. An interim report presenting estimates for haze damage only was submitted to the ASEAN Environment Ministers' meeting in late February 1998 and then to the general public (EEPSEA/WWF 1998a). New estimates (including fire damage) were released on 29 May 1998 (EEPSEA/WWF 1998b). These estimates are discussed in Section 1.4 of this report.

\section{Recommendations (from EEPSEA/WWF 1998b):}

- declare a moratorium on the ' 1 Million Hectare Rice Project' in Central Kalimantan;

- clarify land ownership laws that encourage individuals and companies to clear land as a way of staking a claim;

- enforce existing laws that regulate the use of fire for land clearing;

- make full and prompt use of fire monitoring data provided through regional and international programmes to identify and prosecute those responsible for illegal burning;

- change policies that keep the price of wood to processing mills low, providing little incentive to protect standing timber or to sell scrap wood rather than burn it;

- lengthen the term of leases of forest land to timber companies, which currently leave little incentive to manage forests sustainably - these should be coupled with strict enforcement of regulations governing forestry practices;

- investigate no-burn methods for land clearing - a recent WWF study (Wakker 1998) showed this to be a promising option; and 
- reduce targets for planned forest conversion and instead establish new plantations in unused grasslands of which Indonesia has several million ha.

\section{Policy assessment}

In October 1997, WWF-ID, along with the Indonesian Environmental Forum (WALHI) and the World Resources Institute (WRI), launched a proposal to "study the human and environmental impacts of the fires and haze, to document their direct and underlying causes, and to recommend government policy and procedure revisions' (Schweithelm 1998). WRI concentrates on policy/ institutional analysis and is the report editor; WWFID focuses on economic cost assessment, remote sensing/GIS and ecological impacts, WALHI on impacts on local economies and health impacts, and TELAPAK also on policy/institutional analysis. The report will be published in the WRI Forest Frontiers Initiative series. USAID is supporting WRI in carrying out the policy analysis component.

In May 1998, a thorough overview and discussion of the forest fires in 1997-98, entitled 'The Fire This Time', was published by WWF-ID (Schweithelm 1998).

\section{Assessment of the oil palm business}

Two studies were carried out on the oil palm business. The first carried out a thorough examination of the oil palm industry in Indonesia and the possibilities for 'zero-burning' techniques. The second assessed the role of oil palm in forest conversion and the fires of $1997 / 98$.

\section{The oil palm industry and possibilities for 'zero-burning'}

The objective of this study was to identify options for WWF-ID to promote 'fire-free, zero-burning' techniques for land clearing among oil palm plantation companies in Indonesia. Conclusions in the report by Wakker (1998) include;

- Fire-free land clearing is urgently needed in Indonesia - the benefits are better soil properties, environmental gain and zero air pollution;
- zero-burning is a faster method of clearing land and can lead to an earlier harvest and income;

- zero-burning should be promoted among Indonesian oil palm plantation companies - to achieve this companies should be provided with incentives to overcome the constraints of the technique (higher cost, perceived risk of pests and disease, lack of trained personnel, equipment and clearing contractors);

- WWF-ID should establish collaboration with the palm oil research institutes in Malaysia and Indonesia who are researching zero-burning techniques;

- government should adopt a decree which explicitly states that plantation companies can be fined for any fires observed on their land;

- international banks could be requested to adopt policies to stop financing projects which involve burning as a means of clearing land for development; and

- monitoring of fires in plantations to be carried out routinely by oil palm research institutes.

\section{The role of oil palm in forest conversion and the fires of $1997 / 98$}

Potter and Lee (1998) carried out a thorough study of the expansion of oil palm in Indonesia and its contribution to forest conversion, and fire impacts in and around oil palm estates and their role in causing fires. The recommendations of the report are as follows;

- precise figures on areas and forest type need to be obtained, there is evidence to suggest that forested lands are being converted to make way for oil palm plantations;

- the role of provincial government in producing provincial land use plans must be examined and overhauled;

- local communities must be consulted more in land allocation decisions by provincial government;

- MoFEC must be given more power in the process of land allocation decisions at the provincial level. It must avoid a pro-export bias; 
- estate companies should be encouraged to be more environmentally sensitive in site selection and preparation;

- a certification system for estate companies should be introduced; and

- the role of oil palm expansion in deforestation and in causing the fires of $1997 / 98$ should be studied.

\section{Remote sensing/GIS assessment}

The remote sensing and GIS activities were carried out jointly by the IDRISI Project at Clark University, USA, Department of Geography at George Washington University, USA and WWFIndonesia. According to the final report (Fuller and Fulk 1998) the following approach was used to assess the fire distribution and impacts during 1997 in Kalimantan;

- analysis of NOAA-AVHRR and DMSP-OLS ${ }^{10}$ to validate fire cells mapped using AVHRR channel 3 and determine the most appropriate thresholds for fire detection in Kalimantan;

- analysis of the spatial distribution of fire cells (hot spots) using several different land cover and land use classifications;

- investigation of some new methods for retrieval of fire scars in Indonesia using AVHRR data; and

- GIS analysis of fire scar distribution in relation to land cover patterns.

The main results of the analysis are briefly as follows;

- between August-September 1997 fire cells were most frequent in 'unproductive' wetland environments and peat swamps, although in absolute terms lowland forest had the highest number of detected fires;

- fires were 'problematic' in 'certain' protected areas (PAs), with nine PAs accounting for over $92 \%$ of all fire cells detected in Kalimantan PAs, and $33 \%$ of all PA fire cells detected in Tanjung Puting NP;
- the GIS analysis revealed that fire cells tended to be near rivers and agricultural land;

- the fire scar mapping exercise suggested that between 1.97 and 2.3 million hectares burned in Kalimantan between August and December 1997 (the authors stress that this estimate has not yet been validated with higher resolution imagery).

\section{Biological assessment}

WWF-ID conducted surveys of the impacts on soil, vegetation and species at a number of sites in Kalimantan (including Tanjung Puting National Park and Kutai NP). A preliminary fire impact study was carried out in Tanjung Puting in Central Kalimantan in December 1997 (Lilley 1998; Saleh 1998). Sowerby and Yeager (1997) also produced a report on the effects of fire on wildlife and ecosystem processes. Studies on fire impacts on vegetation diversity and abundance, and fire impacts on primates and other wildlife have also been completed and the results are nearing publication.

\section{Social assessment}

WWF-ID studied the effects of the fires on traditional forest dwellers and more recent immigrants to forest areas in Sumatra and Kalimantan. These studies tried to determine how economic, social and political conditions lead rural people to engage in activities that increase the risk of uncontrolled forest fires, and how the fires ultimately affect the welfare of these communities. Field surveys were conducted in June-July1998 in East Kalimantan on the causes of fire and were presented in a lengthy and thought-provoking report by Vayda (1999).

${ }^{10}$ Defense Meteorological Satellite Program-Optical Linescan System (DMSP-OLS) distributed by the National Geophysical Data Center of NOAA. The advantages of this system for monitoring fires include the wide swath covered by the satellite, the high temporal frequency ( $\sim 15$ times per month) and the high sensitivity to night-time visible observations of fire. 
4.3 ADB - Regional Technical Assistance (RETA) on Strengthening ASEAN's Capacity to Prevent and Mitigate Transboundary Pollution

$\begin{array}{ll}\begin{array}{l}\text { Donor: } \\ \text { Implementing }\end{array} & \text { Asian Development Bank } \\ \text { Agency: } & \text { ASEAN Secretariat } \\ \text { Budget: } & \text { US\$1.2 million } \\ \text { Consultants: } & \text { Senior technical adviser, } \\ & \text { resource/environmental } \\ & \text { economist (team leader), forest } \\ & \text { fire management specialist, } \\ & \text { information management } \\ & \text { specialist, atmospheric sciences } \\ & \text { and meteorology specialist } \\ & \text { (Singapore), policy and } \\ & \text { legislation specialist (Malaysia), } \\ & \text { project manager }\end{array}$

Project Office: ASEAN Secretariat, Jl. Sisingamangaraja, Jakarta 12110

Tel 0217262991,7243372

Fax 021 7398234, 7243504

Team Leader: Erik Scarsborough

Time frame: April 1998-April 1999 (12 months)

\section{Project description}

The RETA was formulated in response to the ASEAN Environment Minister's Jakarta Declaration on Environment and Development on 18 September 1997 and the Regional Haze Action Plan (ASEAN 1997; Pangestu and Ahmad 1997) adopted by ministers on 23 December 1997, which called for such assistance. The primary objectives of the Regional Haze Action Plan (RHAP) are:

\section{Preventive measures}

ASEAN countries will develop national plans to encapsulate their policies and strategies to prevent and mitigate land and forest fires. These plans should contain the following:

- policies and strategies to curb activities that may lead to fires and control emissions, including the prohibition of open burning and strict control of slash-and-burn practices during the dry period;

- operating procedures for early mobilisation of resources to prevent the spread of fires; and

- development of markets for the economic recovery and utilisation of biomass and methods of disposal for agricultural waste.

\section{Regional monitoring mechanisms}

The plan will strengthen the region's early warning and monitoring system. The ASEAN Specialised Meteorological Centre (ASMC) will be strengthened. ASMC will serve as a regional information centre for compiling, analysing, and disseminating information derived from satellite imagery and meteorological data necessary to detect and monitor fires and smoke haze.

\section{Fire fighting capability}

National and regional land and forest fire fighting capabilities will be strengthened through the following measures:

- inventory of fire fighting capability of each country and identification of resources that can be made available;

- formulation of programmes to strengthen the fire fighting capability of individual countries;

- identification of sources of technical assistance within and outside ASEAN and formalisation of an assistance programme; and

- establishment of standard operating procedures for fire fighting.

The Haze Technical Task Force (HTTF) will meet monthly to review the progress in implementation of the Regional Haze Action Plan. The ASEAN environment ministers will meet regularly to provide guidance on the implementation of the plan. HTTF has divided the responsibilities for the Haze Action Plan as follows: Malaysia for prevention, Singapore for monitoring, and Indonesia for fire fighting. 


\section{Project objectives}

The team leader presented the following description of RETA at the inception workshop on 12 May 1998 in Jakarta. RETA is designed to strengthen and formalise cooperation among ASEAN countries affected by the fires and smoke haze through:

- short-term measures required to support early operationalisation of RHAP; and

- medium-term measures required to support and enhance understanding of the transboundary atmospheric haze pollution, and to strengthen the concerned institutions in implementation and institutionalised monitoring of RHAP.

The ASEAN Secretariat Web site (http:// $w w w$.asean.or.id/) is a useful source of information, including details of speeches and meetings relevant to the Regional Haze Action Plan.

\subsection{Advisory Technical Assistance (ADTA) Planning for Mitigation of Drought and Fire Damage - ADB}

\section{Donor: \\ Executing \\ Agency:}

Project Type:

Budget:

\section{Consultants:}

Asian Development Bank (ADB)

BAPPENAS (implementing agency is Bureau Marine, Aerospace, Environment and Technology (BMAEST)

\section{Loan/grant}

US\$ 1.2 million (consulting services, material equipment, air travel, workshops, office space, local transportation). A TA grant of $\$ 1,000,000$. Executing agency (counterpart staff, office facilities, \$200,000.)

\section{Team Leader/Resource}

Economist; Fire Prevention and Control Specialist; Early Warning Systems Design Specialist; Tropical Ecologist/ Climate Modelling Specialist; Fire and Drought Policy
Analyst; Rural Sociologist/

Deputy Team Leader;

Community Forestry

Management Specialist; Food

Security Agronomist; Remote

Sensing/GIS Specialist;

Rainforest Ecologist;

Meteorologist Logging Residue

Utilisation Specialist;

Leglisation and Land Tenure

Specialist. In total 42 person months.

Regions/

Provinces: East Kalimantan and Riau

Contact: $\quad$ Peter King, Senior Project

Specialist (Natural Resources),

Project Co-ordinator, ADB

Manila

Project Leader:

Graham Applegate

Time frame: 8 months (4 for each phase).

Started 20 July 1998.

\section{Project Description}

The following project description and objectives are extracted from the project aide memoire document (ADB 1997) and the Summary Report of Phase 1 (ADB 1999). The ADB funded the TA through the Japanese Special Fund as part of its agreed support to Indonesia to address the economic damages caused by the fires in 1997/98. This TA is also designed to assist BMAEST in bringing about policy reforms and investments to prevent future disasters and to assist with improving drought conditions.

\section{Project Objectives:}

- determine the causes of the forest and land fires and the social, environmental and economic impacts of fire and drought in Indonesia;

- assess the extent to which each of the possible causes was responsible for the uncontrolled fires in 1997/98, and how these could have been 
prevented. This will help to determine future actions;

- assess and evaluate current policies and regulations relating to the use of fire for land preparation, and the efficacy of current methods used in preventing and controlling fire outbreaks;

- assess the need for new approaches to drought management and fire prevention and control;

- determine the cost of the 1997/98 fires and drought to the Indonesian economy; and

- make recommendations on the costs and benefits of investment in prevention, EWS, training and institutional strengthening of the capability and capacity of the population at all levels to prevent and control fires in Indonesia and to ameliorate the effects of drought (Phase 2).

\section{Phase 1 Results}

The first phase (July - November 1998) identified key issues and causes of the fires, and provided policy and institutional advice as background to specific investments to assist in the implementation of a fire management plan in Indonesia (ADB 1998). During this phase a socio-economic survey was carried out over a $1 \frac{1}{2}$ month period in Riau and East Kalimantan. The results and recommendations of Phase 1 are provided in detail in the summary report (ADB 1999).

\section{Phase 2}

Phase 2 commenced in January 1999 is concentrating on the preparation of an investment strategy through the following activities;

- address recommended policy, legislative, and regulatory responses;

- proposals for alternative site clearance methods;

- design, cost and benefits of an improved EWS;

- investment requirements for an expanded national response capability; and

- proposals for institutional strengthening to address future fire and drought management requirements.

\subsection{Environmental Emergency Project- UNDP/State Ministry of Environment}

\author{
Donor: UNDP \\ Budget: US\$ 200000 (for 6 months?) \\ Consultants: 11 national consultants: \\ environmental assessment \\ coordinator, assistant coordinator, \\ biodiversity expert, air pollution \\ analyst, watershed management \\ expert, land resource expert, \\ agricultural expert, environmental \\ health analyst, natural resource \\ economist, communications \\ expert, law enforcement expert; \\ plus 2 international experts: \\ environmental policy and law \\ expert, social impact expert \\ Contact: $\quad$ Project Leader: \\ Hira Jhamtani, UNDP
}

Region/

Provinces: Kalimantan (all provinces) and Sumatra (Riau, Jambi, South Sumatera, West Sumatera)

Time frame: December 1997-May 1998 (this phase completed); some studies started in February 1998 or later.

\section{Project description}

The following project description and objectives have been extracted from a project description provided by the project team leader. UNDP is concentrating its efforts on strengthening the immediate ability of the Government of Indonesia to assess, respond to and monitor the environmental disaster in terms of the interrelated social, ecological and economic consequences. The assistance will provide technical support for evaluating the institutional and policy frameworks that have influenced the disaster and its impacts, to provide the State Ministry of Environment with a strategy for action oriented policy responses. The action plan for forest fire prevention and management will be manifested over three time frames: immediate 
and short-term (1998-99), mid-term (1998-2000) and long-term (1998-2003).

\section{Objectives:}

- organisation of interdisciplinary team to compile action plan format;

- formation of consultative steering committee;

- creation of action plan document; and

- convocation of environmental forum.

\section{Activities}

The objective of this study is to provide a basis for developing a comprehensive plan of action for fire management for the period 1998 to 2003. In order to do so, it is therefore important to understand the causes and effects of the fires and to evaluate prevention and mitigation efforts taken to date.

To achieve the above objective, the team conducted several studies, which include, among others:

- Analysis of the history of forest fires that have occurred in Indonesia between 1982 and 1997;

- Estimation of the economic, social and ecological costs of the 1997 forest and land fires;

- Evaluation of the institution and policies relating to forest and land fires;

- Analysis of the factors that influence the occurrence and spread of forest and land fires;

- Evaluation of prevention and mitigation efforts taken during the 1997 fire crisis.

The final output from the project is in the form of two reports (State Ministry of Environment and UNDP 1998):

\section{Part 1. Land and forest fires: impact, factors and evaluation of efforts}

The objective of this study is to analyse the history, impacts and factors of land and forest fires. This part focuses on an evaluation of efforts to prevent and manage fires in the past to give a broad assessment of its strenghts and weaknesses. The results of the analysis are then used as a basis to provide an insight into design of better land and forest fires prevention and suppression in the future.

\section{Part 2. Plan action for land and forest fires management}

The report describes recommendations to prevent and manage land and forest fires in the future. Major components are institutions building, law enforcement mechanism, management of a fire information system, and communication, information and education system as well as programs to manage forest and land fires.

The project produced three documents, the above two documents and an executive summary. All documents are available in both English and Bahasa Indonesia.

\subsection{ITTO - National Guidelines on the Protection of Forests Against Fire}

In October 1996, a cooperation agreement was signed between ITTO/Common Fund for Commodities, PHPA and the Faculty of Forestry of Bogor Agricultural University (IPB) to formulate National Guidelines on the Protection of Forest against Fire (Integrated Forest Fire Management in Indonesia). The Draft Guidelines (ITTO 1997) were released in October 1997 and discussed at an international workshop held 8-9 December 1997 in Bogor (Suratmo and Coto 1997). The scope of the guidelines includes:

- national policy and legislation;

- forest fire management strategy;

- monitoring and research;

- institutional framework and its development capacity;

- socioeconomic considerations;

- the relationship between forest fire management and forest resource management and utilisation; and

- training and education.

\section{Conclusions and recommendations}

The results of the workshop were as follows:

1. Law and regulations - The guidelines will provide an important basis for the enforcement of existing laws. 
2. Fire detection - There is a need for improvements in accuracy, timing and geographical coverage of detection, and also a need to develop one national fire danger rating system.

3. Fire management and planning - There is an urgent need for detailed and accurate fire statistics.

4. Communications - There is necessity for improved communication, but the need for technology should not overshadow the need for basic fire management issues.

5. Training and education - This is needed in all aspects of fire management and needs to be strengthened, and the need to increase public awareness about fire and to change or modify burning practices also was emphasised.

6. International cooperation - It was recommended that Indonesia cooperate in further fire management development with ASEAN member countries and international organisations.

A report in The Jakarta Post on 9 February 1998 stated that ITTO had agreed to finance a US\$ 1.57 million grant to four forestry projects in Indonesia dedicated to sustainable forestry management. The new grant increases ITTO's donations to US\$ 12 million, which is allocated to 10 forestry projects. The new grant consists of US\$ 125862 to PHPA and IPB to draw up national guidelines on how to protect tropical forests against fire, along with US\$ 672774 for the Indonesian Ecolabelling Agency and US\$ 770000 for the PROSEA Foundation.

\subsection{United States Government}

\subsubsection{USAID's Assessment of the Land and Forest Fire Situation: Interpretation of Satellite Imagery}

In order to address the fire problem, USAID proposed a three-phased approach that includes according to a description by Melnyk, (1997b):

- provision of maps of fires for targeting firefighting activities;

- financial and information support for post-fire assessment; and
- promotion of sustainable land use practices such as reduced impact logging.

\section{Provision of fire maps}

Fire maps are routinely used by the USDA Forest Service (USFS) to target areas for fire-fighting and it was decided that this approach should be tried in Indonesia. In October 1997, the USFS, and USAID in Washington and Jakarta started to make this information available in Indonesia (Melnyk, 1997b). In order to increase awareness regarding these maps in Indonesia, USAID provided technical expertise from USFS for a period of six weeks in Jakarta. These maps were interpreted in the US from classified satellite imagery, and the resulting maps were put on the USFS web site (http:// www.fs.fed.us/eng/indofire). Some examples can be seen in Appendix 3. USAID encouraged requests for maps of specific areas. Fire maps covered Sumatra and Kalimantan, during the period 21 October - 30 November 1997, in total 24 fire maps were posted on the web site. In 1998, from 7 February to 13 March 1998, another 24 maps mainly for East Kalimantan were made available.

\subsubsection{East Asia and Pacific Environmental Initiative}

The US Government started the Southeast Asia Environmental Initiative (SEA-EI) in 1998 as a medium to long-term response to environmental degradation and its negative economic, social and political impacts.

\section{Activities (\$4.8 million obligated)}

In response to the haze crisis, the US Government organized an Inter-Agency Working group (IWG) to develop proposals for longer-term USG followup assistance to the short-term fire fighting assistance provided from September to December 1997. The proposals were approved by the IWG in meetings held from March to June, 1998. 
SEA-EI was developed to address the repeated fire and smoke episodes, working collaboratively with other donors and nations in the region. This involved a three-pronged strategy:

a. Better forest management techniques and policies;

b. Improved fire prevention and fighting; and

c. Improved climate-impact forecasting and environmental monitoring.

\section{Better forest management techniques and policies}

For better forest management techniques and policies. Three activities are now underway to:

a. assess the underlying causes and impacts offires in Southeast Asia;

A comprehensive study is underway by CIFOR and ICRAF, and the USDA Forest Service.

b. demonstrate reduced-impact harvesting technologies that reduce fire risk in tropical forests; Work on reduced-impact harvesting is underway by the USDA Forest Service through collaborative network, including the Indonesian Ministry of Forestry, the Association of Indonesian Concession Holders, CIFOR, the Tropical Forest Foundation (a U.S. NGO);

c. develop alternatives to destructive slash and burn agricultural practices. US assistance for this activity is being provided to the Southeast Asia regional program of ICRAF.

\section{Improved fire prevention and fighting}

For improved fire prevention and fighting, there are two activities to:

a. strengthen ASEAN fire/disaster response coordination;

The USDA Forest Service is providing technical assistance and training to help ASEAN develop the appropriate national and regional mechanisms to ensure that resources are coordinated and available at the right place and time.

b. build Indonesian and regional capacity to extinguish coal seam and peat fires.
The Department of Interior, Office of Surface Mining is providing on site training and demonstration courses in locating, characterizing, and implementing abatement and suppression of coal seam and peat fires.

\section{Improved climate-impact forecasting and environmental monitoring}

For improved regional climate-impact forecasting and environmental monitoring capability, the activities are:

a. improvement the infrastructure and capacity for establishing regional applications of global climate change models by the NOAA Office of Global Programs, working with the ASEAN Specialized Meteorological Center (ASMC) and national agencies;

b. monitoring and modeling smoke and haze by the NOAA/National Weather Service through the Program to Address ASEAN Regional Transboundary Smoke (PARTS).

c. developing an early warning system by the US Environmental Protection Agency (USEPA) to predict air quality problems;

d. investigating the negative health impacts of air pollution, particularly from fires and haze by the by the U.S. Center for Disease Control and Prevention (CDC), in cooperation with the national Ministries of Health (MOHs), the Malaysian Institute of Medical Research (IMR), and the Indonesian National Institute of Health Research and Development.

e. improving the access to climate related information to be used by decision makers, program designers, and implementers for improved disaster contingency planning by the USAID Office of Foreign Disaster Assistance (OFDA) working with the Asia Disaster Preparedness Center (ADPC) in Thailand.

\section{Activities}

The program areas and types of activities particularly relevant to fires considered for 1999 support are: 


\section{Forestry and Land Use Management}

a. Additional fire and haze preparedness assis-tance as requested by the ASEAN Haze Task Force to implement recommendations from Regional and National Haze Actions Plans and from USDA Forest Service FY98 assistance.

b. Workshops and supplemental policy analysis to refine and gain acceptance for recommendations from the FY98 CIFOR assessment of causes and sources of fires. These will include ASEAN, national agencies, and NGO policy groups.

c. Extension of improved land management practices involving agroforestry systems and technologies identified by ICRAF through indigenous NGOs.

d.Further analysis of regional deforestation problems and causes [with a likely focus on mainland Southeast Asia] will be pursued through special studies and regional workshops.

\subsection{Centre for Remote Imaging, Sensing and Processing (CRISP), Singapore}

The Centre for Remote Imaging, Sensing and Processing (CRISP) is a research centre of the National University of Singapore. CRISP's mission is to develop an advanced capability in remote sensing to meet the scientific, operational and business requirements of the region.

CRISP operates a satellite ground station to acquire data from SPOT, ERS and RADARSAT remote sensing satellites, and processes the archived data to standard or value added products for distribution. Special products are custom processed to user requirements, or training/consultation services in the field of remote sensing are offered. CRISP has been acquiring SPOT imagery since September 1995, ERS 1 and 2 since March 1996, and RADARSAT since May 1997.

As fires started to show up on SPOT imagery, CRISP processed these images and placed them on its Web site (http://www.crisp.nus.edu.sg/) as examples of forest/plantation fires and smoke haze.
Currently, there are 12 temporal sequences of images for 1997 and 1998 covering Indonesia (Kalimantan and Sumatra), Sarawak, West Malaysia, Brunei and Western Australia (Map 8, Appendix 3, is an example of a temporal sequence over Central Kalimantan).

CRISP also undertakes research in optical and microwave remote sensing technology and applications. One of the current research initiatives involves mapping the extent of the Indonesian fires and has the following objectives. ${ }^{11}$

- Burnt area estimation using SPOT quicklook mosaics - The burnt areas in Sumatra, Kalimantan and Sulawesi were mapped and delineated using mosaics of SPOT quicklook images before (January-June 1997) and during (August-December 1997) the 1997 fires to estimate the total area burnt and the types of land cover on fire. Some preliminary estimates have been released by CRISP and they were used in the WWF-ID and EEPSEA estimation of the economic cost of the fires and haze (Section 1.4). The estimates are based on a total burnt area of 5 million ha. For Sumatra and Kalimantan, the breakdown of area burnt by land use is $20 \%$ forest, $50 \%$ agriculture/ plantation and $30 \%$ other (unproductive).

- Temporal and spatial distribution of hot spots detected in AVHRR images - Daily NOAA-14 AVHRR images from July to October 1997 have been processed for hot spot detection; animations of the temporal evolution and spatial distribution of the hot spot density images have been produced.

- Change detection using ERS SAR images - Maps showing change in radar backscatter ${ }^{12}$ of the fire-

${ }^{11}$ Personal communication, Soo Chin Liew, CRISP, 26 May 1998.

12 Backscatter is the microwave signal reflected by elements of an illuminated scene back in the direction of the radar. It is named as such to make clear the difference between energy scattered in arbitrary directions, and that which returns to the radar and is received and recorded by the sensor (Henderson and Lewis 1998). 
affected areas will be produced using ERS images of 1996 and October 1997. The areas with high change in radar backscatter are correlated to the burnt areas extracted from SPOT.

- Study of fire-affected areas using interferometric $S A R$ - Interferometric coherence ${ }^{13}$ map of selected fire-affected areas in Kalimantan have been processed from the ERS data acquired during the ERS tandem missions in April-May 1996 and October 1997; burnt areas can be correlated to the areas undergoing change in coherence.

- Daily fire monitoring operation - CRISP is currently engaged in daily fire monitoring to provide information about fire outbreaks in the region. SPOT images are acquired over fire outbreak areas. The high-resolution images are visually inspected to detect smoke plumes associated with fires to provide the exact locations of fires and to assess the extent of fires and types of land cover on fire. This information is relayed to the Ministry of Environment, Singapore, for further dissemination to relevant authorities in the region.

\subsection{South East Asian Fire Experiment (SEAFIRE)}

SEAFIRE is a planned research programme under the International Geosphere-Biosphere Programme (IGBP) that is intended to clarify the origin, mechanisms of transport and impacts of fire emissions on the regional and global atmosphere (Goldammer 1997). The aims of the initiative were established at a meeting of the SEAFIRE Scientific Steering Committee in Samarinda in June 1995. SEAFIRE started in 1996 and will continue until $2000 .{ }^{14}$

SEAFIRE will explore the ecological impacts of fire in land use (fires used in forest conversion and shifting cultivation, grassland and seasonally dry [monsoon] forests) and the characteristics, regional and global transport mechanisms, and atmospheric chemical impacts of pyrogenic emissions. Biogenic and marine sources of trace gases and aerosols will be considered, as well as technogenic sources (fossil fuel burning, secondary chemical products). Special emphasis will be given to interannual climate variability (ENSO vs. nonENSO) and the role of the 'warm pool' in global distribution of fire products.

SEAFIRE's operational approach is twofold. First, SEAFIRE will build on existing data and research results. It plans to collaborate with research institutions (government, universities) of ASEAN nations that are working in fields relevant to SEAFIRE objectives (such as meteorology, remote sensing and air pollution monitoring). BPPT will be the collaborating agency in Indonesia. Second, a set of small and large field research campaigns are planned to address the open questions that are largely in the field of emissions chemistry and transport. Such field research will be conducted on the ground, and on air-, spaceand ship-borne platforms.

\subsection{Monitoring Tropical Vegetation Unit of the EC}

The Monitoring Tropical Vegetation (MTV) Unit of the Joint Research Centre of the European Commission (JRC) runs two projects that address tropical deforestation and fires.

The key objective of the Fire in Global Resources and Environmental Monitoring (FIRE) Project is to document biomass burning patterns for the entire tropical belt and analyse such patterns in relation to land use/land cover dynamics. In the near future, the experience, tools and skills gained from this ongoing activity will contribute to definitions of new activities in relation to forest fires, namely, forest fire propagation modelling and burnt area mapping.

\footnotetext{
${ }^{13}$ Interferometric coherence uses two different paths for imaging, and deduces information from the coherent interference between the two signals. In radar applications, spatial interferometry has been used to measure terrain height (Henderson and Lewis 1998).

${ }^{14}$ The preceding information is from the SEAFIRE Web site (http://www.geography.monash.edu.au/ seafire/).
} 
The unit has launched two research activities for the detection and mapping of burnt areas using AVHRR data and data from the ATSR sensor on board the European Remote Sensing satellite. A standardised set of biomass burning products has been implemented at different scales - global, regional and local — and made available to external users.

To address changes taking place in the forests of the tropical belt, the Tropical Ecosystem and Environmental Observation by Satellites (TREES) Project studies tropical forest dynamics at regional and global scales using remote sensing techniques for a worldwide tropical forest inventory. Data were derived from the NOAA AVHRR low spatial resolution instrument and the ESA ERS-1 Synthetic Aperture Radar (SAR) instrument. The areas covered are Southeast Asia, Central and West Africa, and South and Central America. Methods are being developed for the detection and monitoring of the active deforestation areas and measurement of deforestation rates at critical sites, including a number in Indonesia. More information can be found on the JRC Web site (http:// www.jrc.org/sai/mtv/activities).

\subsection{IC-SEA's (Impacts Centre for Southeast Asia) Land Use Planning and Management to Reduce the Impacts of Transboundary Pollution from Fires in Southeast Asia}

As part of the international global change science programmes, the Global Change Impacts Centre for Southeast Asia (IC-SEA) has been developing a policy support role to address large-scale environmental problems and sustainable development issues in the region. For more information, please visit the Web site, http:// www.icsea.or.id/sea-span/SCIPOL2/.

The main aim of IC-SEA's programme is to identify the land use planning, clearing and subsequent management options that would reduce the risks of transboundary haze problems from fires and to explore plausible policy instruments for implementing the most promising technical options. This would then be incorporated in the long-term objective to improve land use planning and management in Southeast Asia in ways that make them more sustainable.

To achieve this objective a series of activities are proposed. These begin with a set of commissioned reviews and interviews, and proceed through a series of small review and synthesis meetings to electronic workshops, and end with briefings and a forum to be held in collaboration with the ASEAN Secretariat. The ultimate product should be an ongoing network with ASEAN involvement to address this and other large-scale environmental problems and promote better strategies for sustainable development of the Southeast Asian region. The four commissioned reviews cover the following topics:

- waste-wood management;

- stakeholders perceptions;

- domestic and international policy responses;

- air pollution cause by haze from forest fire;

- internet Web site to support process and possible on-going activities;

- a synthesis report on the entire process to IGBP as part of IC-SEA Report Series; and

- Policy briefing document for ASEAN. 


\section{Proposed Fire Projects}

\subsection{CIFOR, ICRAF and UNESCO - The Underlying Causes and Impacts of Fires in Southeast Asia}

\section{Summary}

CIFOR, ICRAF and UNESCO propose to conduct a timely and detailed assessment of the location, nature, and underlying causes and impacts of recent and historic fires in Southeast Asia, particularly in Indonesia. It is envisaged that the research will take three years to complete. The results of the assessment will be used to foster key policy changes needed to reduce the severity of future fires. This fire research harmonises well with ongoing research programmes of both CIFOR and UNESCO; e.g., CIFOR's research to assess underlying causes of deforestation, and the Alternatives to Slash-andBurn (ASB) Project of ICRAF, CIFOR and UNESCO.

The causes of the fires are poorly understood, and this is highlighted by the way in which the blame has been attributed to various groups and influences, including small farmers, agricultural land conversion schemes, forestry concessions, industrial plantations projects, indigenous peoples, other land users and the ENSO phenomenon. A number of critical questions remain unanswered:

- How much forest and non-forest land burned?

- What were the previous land uses?

- When did fires occur?

- Who set the fires and why?

- What relative roles did largeholders and smallholders play in the fires?

- How do tenure conflicts contribute to causes of the fires?
- What is the distribution of land intentionally and accidentally burned?

- What social impacts do the fires have on local communities?

- What are the post-fire land uses of the burnt area?

- What proportion of the burnt area will regenerate and what area will remain permanently deforested, and why?

This lack of basic information has contributed to a general sense of confusion regarding the nature of the fires, their causes and impacts, and areas likely to be at risk in the future.

\section{Activity description}

CIFOR, ICRAF and UNESCO propose a threetier approach to the research:

- a general overview of the fire situation for the whole archipelago;

- a more detailed assessment at the level of Sumatra and Kalimantan to assess to the extent that characteristics of fires in those provinces are representative of the Indonesian situation as a whole; and

- a detailed assessment of causes and impacts at the site-specific level, i.e., several detailed study sites in Kalimantan and Sumatra.

The general assessment will identify where and when fires have occurred in Indonesia over time, while the site-specific assessment will determine which actors/agents have caused certain types of fire over time and why. The results from both levels will provide input to the development of guidelines for local fire management. 
The research will generate knowledge that will help Southeast Asian nations be better prepared the next time an abnormally dry year occurs. In this context, it is important to involve Indonesian (and Southeast Asian) scientists in this research. It is also important to disseminate the results of the research to policy makers and to parties carrying out local fire prevention and mitigation initiatives.

\section{Current status of the proposal}

The final version of the proposal was completed at the end of April 1998. The total budget for the 3 -year period is estimated at US \$3.4 million. The research is constructed in a modular fashion so that donors have the option of funding certain modules. It is envisaged that the research will be supported by several donors. Funding for some activities in the first year has already been allocated by the US State Department (US\$ 700 000). Part of this money will be allocated to the US Forest Service (CIFOR and USFS already have working linkages), who will provide technical support in image analysis and fire risk modelling.

\subsection{IUCN and WWF - Project 'Firefight' to Establish a Collaborative Global Network for Forest Fire Prevention and Control}

\section{Project Summary}

The project will document the impact of fires, identify underlying causes, and put in place both a national and global level collaborative Fire Prevention and Control Network that will ensure that the world's forests are adequately protected and sustainably managed for the benefit of all humanity and for preservation of the global environment (IUCN/WWF 1998). Consisting of three phases, the project is budgeted for 2-3 years, with a preliminary estimated budget of US\$ 3 million.

\section{Overall objectives:}

- to raise public awareness of the detrimental impacts of fires;

- to improve forest fire management worldwide; and

- to eliminate the adverse environmental, social and economic impacts of forest fires.

\section{Specific objectives:}

- to identify the main underlying causes of forest fires, including a better understanding of the motivation of different interest groups whose activities contribute to increased fire risk;

- to identify technical, regulatory, institutional and fiscal policy mechanisms for fire prevention and control; and

- to establish at national, regional, and global levels fire prevention and control institutional mechanisms that will engage local communities, the private sector, industry, conservation agencies, national governments and international agencies in a collaborative network - the network will include improved EWS and an Emergency Fire Fighting Task Force capability that can be mobilised to assist national governments facing major forest fires

\section{Phase 1}

The main activity of project 'Firefight' will be a series of five regional consultations aimed at achieving consensus and high level political commitment on remedial action. The first meeting in December 1998 will focus on Southeast Asia.

It is envisaged that a large number of agencies will collaborate in Project 'Firefight', such as ASEAN, Conservation International, CIFOR, EC, FAO, GEF, Green Cross, ICRAF, International Federation for Animal Welfare, Regional Development Banks, The Nature Conservancy, UNDP, UNEP/OCHA, UNESCO, UNICEF, US State Department, WCMC, WFP, WHO, WMO, the World Bank and WRI. 


\subsection{ACIAR ( Australian Centre for International Agricultural Research) - Fire Management Systems for Sustainable Agricultural and Forestry Development in Eastern Indonesia, Review Workshop}

\section{Project summary}

Eastern Indonesia has a semi-arid climate with large areas of savannah vegetation, and consequently is fire prone. The region faces major problems of land and forest degradation. Fire is a fundamental component of traditional and current land management. Although the extent, severity and impacts of fire appear to be increasing, these changes are poorly documented. There is little understanding of the processes affecting fire behaviour in eastern Indonesia and the steps necessary to better manage fire (ACIAR 1998).

\section{Project Objectives:}

- to establish links with the network of current activities relating to land management in eastern Indonesia by a field trip through Nusa Tenggara; and

- to review fire management in eastern Indonesia and northern Australia at a workshop in Darwin, to discuss the problem of regional haze, and to summarise recommendations and resolutions generated by the discussion phase.

The immediate benefits of the workshop will be the efficient exchange of information and the opportunity for productive discussions between scientists with expertise in fire management, land managers, and representatives of the Indonesian Ministries of Forestry and Agriculture. Greater benefits will follow from future research and training projects conducted as a result of research priorities identified at the meeting. The field trip will take place in the second half of 1998 and the workshop in the first half of 1999. 


\section{Indonesia's Response to the Fires and Smoke Haze}

The Government of Indonesia has several organisations charged with preventing, monitoring and controlling forest and land fires. During normal years, monitoring of fires and prevention is the responsibility of the Ministry of Forestry's SubDirectorate of Forest Fires within the Directorate General of Forest Protection and Nature Conservation. However, during years when fires reach disastrous proportions, such as in 1997, other government agencies, such as the National Coordination Board for Disaster (BAKORNAS PB), take overall responsibility. The following chapter describes the role played by various government agencies during the fires of 1997-98.

For a comprehensive review and description of the response by government agencies prior to 1997 consult the reports of the Ministry of Environment/UNDP (1998) and Siswanto et al. (1997).

\subsection{National Coordination Team for Land and Forest Fire Control}

Following the forest and land fires of 1994, the National Coordination Team for Land and Forest Fire Control (TKNPKHL) was established in 1995. The team is headed by the State Minister for Environment and the Director General of Forest Protection and Nature Conservation (PHPA). Members of the team include senior officials from the Ministries of Home Affairs, Mining and Energy, Agriculture, Transmigration, and Social Affairs, and from LAPAN, BAPPENAS and BPPT. The deputy head of the team and the secretariat are located at BAPEDAL. The team's activities include:

- organising local capability and coordination to prepare for fires;

- developing techniques to control fires using various management approaches;
- operating a fire detection and EWS; and

- communicating and cooperating with international agencies and foreign countries affected by smoke and haze from Indonesia.

In mid-August 1997 BAPEDAL, in its capacity as secretariat of the TKNPKHL, established an emergency command post (POSKO) to coordinate efforts to monitor and control land and forest fires. POSKO was mostly staffed by BAPEDAL and volunteers. It had responsibility to compile information, including land visibility and hot spot locations from NOAA AVHRR provided by LAPAN, and disseminate it to government agencies and provincial governments. Daily fire hot spots for each affected province were available on the BAPEDAL Web site (http://www.bapedal.go.id/ poskodal) from mid-September to November 1997. An example of the output can be seen in Appendix 1, Map 4. The coordination centre also relied on information provided by the public, media, the Geophysics and Meteorological Agency (BMG), BPPT, Singapore and Malaysia. POSKO was on alert 24 hours a day until November.

Under normal fire conditions, TKNPKHL provides technical input and information to provincial coordinating teams, which instruct district teams and field units. Fire suppression teams are the responsibility of each individual land user or concessionaire. With the onset of the extended dry season in 1997, TKNPKHL decided to strengthen fire control activities (Makarim et al. 1997; Purnomohadi 1997) and from February the following actions were initiated:

- the status of fire was elevated to a disaster (15 September 1997); in response, an emergency command post (POSKO) for fire control opera- 
tions was established by the Coordinating Agency for National Emergencies (BAKORNAS PB), ${ }^{15}$

- a moratorium on land clearing and burning was declared, and the President declared a ban on all land clearing activities;

- the names of companies using fire to clear land were publicised;

- GIS and remote sensing was used to monitor forest fires;

- weekly reports from governors were requested;

- concessionaires were required to submit weekly reports of land clearing and burning in and adjacent to their concession areas;

- air- and ground-based suppression operations (such as cloud seeding) were instituted;

- international fire fighting experts arrived in September to assist and advise TKNPKHL; and

- international dialogue and cooperation was strengthened.

\section{Response to the 1998 fires in East Kalimantan}

In mid-January 1998, BAPEDAL sent a team to East Kalimantan to investigate the fire situation. It also reactivated its emergency command post (POSKO) in Jakarta. The POSKO collected evidence regarding illegal fire setting in Sumatra and Kalimantan.

\subsection{Ministry of Agriculture}

At the time of the fires, the Ministry of Agriculture held major responsibility for plantations. It gave 242 plantation companies a 15-day deadline to prove their non-involvement in forest burning. Twentynine of these companies had not responded by midNovember 1997, and the Ministry of Agriculture was to follow up accordingly. Plantations are now the responsibility of the Ministry of Forestry and Estate Crops.

\subsection{Ministry of Forestry}

The Ministry of Forestry revoked 166 wood use permits of plantations and timber concessions after they failed to present evidence disproving that they had started land and forest fires. The Ministry accused 176 companies of violating strict laws against burning. Fire hot spot data, satellite imagery, and GIS were used in many cases to pinpoint the culprits (see Section 1.4).

The Ministry deployed 8437 fire fighters divided into 560 teams in 17 provinces to handle fires in forest concession areas and industrial timber estates. Some 4530 were deployed to South Sumatra, 678 to East Kalimantan and 311 to Riau. This effort also included the deployment of 73 bulldozers, 80 tractors, 24 excavators, 22 loaders, 23 graders, 77 trucks, 92 water tank vehicles, 94 chain saws and 225 water pumps to 17 provinces. The Ministry reportedly set aside Rp. 3.1 billion to handle the forest fires, with Rp. 2.6 billion from the reforestation fund and the rest from central government budget. The Ministry also allocated Rp. 40 million to BPPT, which implemented cloud seeding (The Jakarta Post, 29/9/97).

\section{Response to the 1998 fires in East Kalimantan}

The Ministry of Forestry sent teams to investigate the fires, and the Minister and several of his Directors General flew over the area in February. The Ministry identified Kutai NP and Bukit Soeharto as priority areas for its fire fighting efforts. Ground crews and water bombers were used in these areas. Logging concessions and timber estates were responsible for their own fire fighting; it was estimated that there were 253 fire fighting units with 1472 personnel (UN OCHA 1998a).

\footnotetext{
${ }^{15}$ BAKORNAS PB was established in 1979 with responsibilities to formulate policy and provide guidelines and directives related to natural disaster management; coordinate disaster management before, during and after the disaster in an integrated manner; and provide guidelines and directives on policy outlines and disaster management activities covering prevention, mitigation, response, rehabilitation and reconstruction. It is chaired by the Coordinating Minister for People's Welfare.
} 


\subsection{Ministry of Health}

The Ministry of Health faced an enormous task with limited resources. As of early September, the Ministry had distributed protective face masks to the affected regions of Sumatra and Kalimantan, as well as disseminating information to the public regarding safety measures it should undertake. The Ministry also conducted health assessments in the worst affected provinces, such as Jambi in Sumatra.

\subsection{Others}

The relief effort was strengthened by armed forces, police and local government authorities, especially in fire fighting. The following personnel were deployed in the field: 3910 soldiers, 1050 members of the police force, 1800 forest rangers, 30700 volunteers, 1 ship, 8 aircraft and miscellaneous equipment.

\subsection{NGO Relief efforts}

\section{Indonesian Environmental Forum (WALHI)}

Eight thousand protective masks were sent to
Kalimantan (The Jakarta Post, 26/9/97), and there was also a public campaign for donations; 105250 masks were sent to Kalimantan and Sumatra (The Jakarta Post, 15/10/97). By mid-October, the group had raised Rp. 104435000 from public donations (The Jakarta Post, 15/10/97). WALHI carried out investigations of the fires in five provinces (South Sumatera, Lampung, East, West and Central Kalimantan). The findings were compiled and published in WALHI's magazine "Tanah Air" (WALHI, 1998).

\section{National Consortium for Forest and Nature Conservation in Indonesia (KONPHALINDO)}

KONPHALINDO opened command posts in Jakarta, Pontianak, Banjarmasin and Samarinda to assist people in overcoming the haze problem (The Jakarta Post, 15/10/97).

\section{Indonesian Red Cross}

In Jambi, the organisation provided more than 40 000 masks, 400 grams of honey and 300 boxes of medicine to provincial authorities. 


\section{International Relief Assistance}

As a result of the emergency situation brought about by the fires and drought, Indonesia received international assistance in cash and kind. The Government of Indonesia did not formally appeal for international assistance but clearly indicated that it would welcome such support. The following chapter includes a list of UN agencies, countries and international organisations that offered and donated assistance.

\subsection{UN OCHA in 1997}

In response to the escalating fire and drought emergency, a United Nations Disaster Assessment and Coordination Team (UNDAC) was dispatched to Indonesia at the end of September 1997 (United Nations 1997). The team was sent by the UN Office for Coordination of Humanitarian Affairs (formerly UNDHA) to assist the UN resident coordinator and the government in needs assessment, resource mobilisation and coordination of international assistance (The Jakarta Post, 15/10/97). Field assessment missions were conducted in Sumatra (Lampung and Jambi), Kalimantan and Irian Jaya for two weeks. An emergency grant of US\$ 50 000 was provided by OCHA.

The UNDAC field teams supplied fire fighting and medical equipment and expertise. In addition, a general assessment was made of the impacts of the disaster, including an evaluation of fire fighting equipment and training, health care, drinking water, food, relief items and logistics. Field assessment missions convened meetings with local authorities, fire fighters, medical personnel, academic institutions, NGOs and logging companies. The following points arose from the field missions and are presented in the final mission report (United Nations 1997):
1. Ground fire fighting and training - This was one of the most pressing problems. A Joint Technical Coordination Group on Fire Fighting was established by UNDAC in Jakarta, which brought together government bodies and representatives of the donor community to exchange relevant information and avoid duplication of effort; BAKORNAS/UNDAC estimated that 43 basic response packages and 12 fire fighting packages for peat fires were required for Riau, Jambi, South Sumatra, Lampung, Kalimantan and Irian Jaya at a cost of US\$ 1.24 million.

2. Health care - Provision of medicines for respiratory infections, asthma, conjunctivitis and diarrhoea was recommended for severely affected provinces; necessary steps were taken to purchase the medicines in Indonesia.

3. Drinking water - The drought raised serious concerns about the safety of drinking water in Irian Jaya, Kalimantan, Jambi and South Sumatra.

Conclusions and recommendations of the mission (United Nations 1997) include:

- the emergency had an important international dimension because of the severe transboundary pollution and the large-scale destruction of unique aspects of the existing biodiversity, which is of world importance;

- substantial international assistance was given to Indonesia, and OCHA played an important role in coordinating the relief efforts;

- although the peak of burning has passed, the risk of fires was still great and the situation must not be considered stable; efforts to ban the use of fire for land clearing must be vigorously pursued;

- national authorities should considerably improve preparedness to combat future fires;

- information sharing at national and international level should be improved; 
- an assessment of environmental and other damage should be carried out;

- early warning capacities, both national and international, should be further developed; and

- OCHA should continue monitoring the situation.

The international community pledged cash contributions valued at more than US\$1.5 million, of which $\$ 630000$ has been channelled through the UNHDA.

\subsection{UN OCHA/UNEP in 1998}

Because of the worsening drought and fire situation in East Kalimantan, a UNDAC Team (including two members from UNEP) was dispatched to Indonesia on 28 March 1998 for one month. The task was to assess the impact of the fires in East Kalimantan, including regional and global environmental concerns, and the evaluation of the needs of complementary international assistance (UN OCHA 1998a).

\section{Conclusions}

The final mission report (UN OCHA 1998a) contains the following conclusions:

- the disaster caused considerable ecological damage in East Kalimantan, as well as having substantial negative effects on the social, economic and health sectors;

- the fire situation was out of control;

- control was beyond the capacity of the available manpower, and the immediate future was bleak unless assistance was provided or sufficient rain fell; and

- the effectiveness of water bombing should be critically assessed - it is expensive and its effectiveness is questionable unless mobilised in early fire development.

\section{Recommendations}

A number of recommendations were proposed (UN OCHA 1998a):

\section{Short-term}

- immediate international assistance should be provided to contain fires in East Kalimantan, with special attention for national parks and protected areas and primary forest;

- immediate action should be mobilised to prevent fires from becoming an economic and environmental threat to other areas in Kalimantan and Sumatra;

- assistance should be targeted at institution strengthening for emergency response, prevention and preparedness by Indonesian agencies; and

- rapid appraisal and assessment of the current damage should be implemented, with attention paid to the impact on people, property and protected areas.

\section{Long-term}

- early warning capacities at international and national levels should be further developed and utilised;

- fire awareness should be directed at the public, smallholders, largeholders and the government;

- sustainable forest management should be developed in accordance with Objective 2000 of ITTO; and

- UNEP and OCHA should initiate international consultations to elaborate appropriate agreements or other legal instruments to cover issues related to fire risk assessment, early warning, data exchange, mutual assistance and other matters.

\section{Follow-up}

On 20-21 April 1998, UNEP and OCHA organised an international meeting in Geneva. A workshop attended by fire fighting experts was held on the first day. The experts identified immediate needs in controlling the fires and contributed to the formulation of an emergency action plan to be undertaken by the international community. These 
measures consist of fire fighting packages, training, expertise, special aircraft support, communications and coordination (UN OCHA 1998b).

The second day was a meeting of international organisations focussing on medium- and long-term solutions. An information meeting of the donors concluded the discussions.

The sum requested by OCHA and UNEP to carry out the recommendations was almost US\$ 10 million. This covered the provision of essential equipment and training for local fire fighters, the use of aircraft (US\$ 3 million), operational management and communications support to government liaison teams. Detailed information regarding UN OCHA/UNEP progress in raising the funds can be found at the OCHA Web site (http:// www.reliefweb.int).

\subsection{Other UN Agencies}

\section{UNICEF}

Provided 21650 face masks (costing US\$ 20 000), a water supply project (US\$10 000) and medicines for children in Sumatra and Kalimantan.

\section{UNESCO}

Funded a water supply project (US\$ 5000).

\section{WHO}

Provided a cash donation of US\$ 200 000, air particle samplers and health advisers.

\subsection{Donor Countries}

\section{Australia}

Provision mainly of fire fighting and medical aid (A \$ 1 million). Two Australian water bombers were deployed in Lampung (early October 1997) as part of a 15-man fire fighting team. Australian advisers also prepared a rapid assessment on the Indonesian fire emergency for Irian Jaya and Lampung. The Australian government announced that it would provide A \$280 000 to the Australian Red Cross to assist Indonesia in dealing with the effects of the haze blanketing the archipelago (The Jakarta Post,
15/11/97). In total, Australia donated more than US\$ 2.6 million in cash and kind directly or through UN agencies and NGOs.

\section{Canada}

Forest fire specialists were seconded to BAPEDAL. Canada also offered to co-fund a C\$ 2 million ASEAN Regional Forest Fire Cooperation Project aimed at developing a long-term wildfire response strategy, information systems and action plans. The Canadian Forest Service made a prototype ASEAN Fire Weather Information System (AFWIS) available. A demonstration of AFWIS can be seen on the Canadian Forest Service Web site (http:// www.nofc.forestry.ca/fire/asean/). The Web site shows up-to-date examples of AFWIS input maps (temperature, dew point, relative humidity, wind speed, wind direction, precipitation, days since rain, visibility) and output maps (fine fuel moisture code, duff moisture code, drought code, initial spread index, build-up index, fire weather index). An example of a precipitation map and a fire weather map can be found in Appendix 3.

The Canadian-funded Collaborative Environmental Project in Indonesia prepared a brief assessment of the Indonesian land and forest fires in 1997 (Goodman et al. 1997). In total, Canada donated more than US\$ 1123000 in cash and kind directly or through UN agencies and NGOs.

\section{Denmark}

Provision of cash contribution of US\$ 38000 for the purchase and installation of drinking water supply.

\section{Finland}

Provision of fire fighting expertise and equipment for peat fires, to the value of US\$ 56500 . Also offered fire fighting equipment in February 1998.

\section{France}

Donated Rp. 275 million (US\$ 78 571) worth of fire fighting equipment and trainers. Also offered fire fighting equipment in February 1998. 


\section{Germany}

Provision of fire fighting expertise (one member to UNDAC), training of fire fighters and humanitarian relief. Spearheaded the Integrated Forest Fire Management Project in East Kalimantan. The German Embassy offered a donation of DM 100,000 (Rp. 201 million) in aid for medical supplies and other humanitarian relief measures (15/ 10/97). It offered an additional DM 500000 (Rp. 1 billion) for equipping 400 fire fighters and establishment of a central fire tool cache in Samarinda.

\section{Japan}

Provision of fire fighting equipment and humanitarian aid (300 portable water cannons worth Rp. 430 million, along with protective masks and medicine). Also sent a team of 43 experts, mainly to Sumatra, for monitoring by helicopters (2) with special cameras. Japan's National Space Development Agency undertook a Biomass Burning and Lightning Experiment study (tropospheric and stratospheric chemistry over Indonesia).

The Japanese government presented a supply of items worth US\$ 80375 to the Indonesian Red Cross for people suffering from haze (The Jakarta Post, November 1997). In total, Japan donated more than US\$ 3130000 in cash and kind directly or through NGOs. Japan also offered fire fighting equipment in February 1998.

\section{Malaysia}

Sent 1210 fire fighters to Riau, Jambi, South Sumatra and East and West Kalimantan (24 September 1997). Paramedics were also sent. The Malaysian government also offered three C-130 Hercules planes to take part in cloud seeding operations with the Indonesian Air Force (September 1997).

\section{New Zealand}

Offered to provide US\$200 000 in assistance to help combat the bush fires and deal with their aftermath. The aid, in the form of tools and equipment, was to be made available through UNDHA.

\section{Norway}

Norway provided one UNDAC member, as well as cash through UNDHA. In total, Norway donated more than US\$ 322000 in cash and kind directly or through UN agencies. It also offered fire fighting equipment in February 1998.

\section{People's Republic of China}

China offered US\$ 120000 in fire fighting equipment and medical relief (The Jakarta Post, 15/11/97). It also offered fire fighting equipment in February 1998.

\section{Russian Federation}

Dispatched three fire fighting experts at a cost of US\$ 17000.

\section{Singapore}

Provided one C-130 plane.

\section{South Korea}

Donated US\$ 100000 to help fire victims.

\section{Sweden}

Dispatched one fire fighting management expert, one relief coordination expert and 10 basic fire fighting packages, at a total cost of US\$ 203000.

\section{Switzerland}

Provided one UNDAC member.

\section{Thailand}

Offered to send two C-130 water bombers (September 1997). Also sent six fire experts from the Ministry of Agriculture and Forestry (The Jakarta Post, 5/ 10/97), with the intention of visiting Sumatra and Kalimantan, at a total cost of US\$ 50000. 


\section{Taiwan}

Sent 100000 masks and 20 tonnes of rice.

\section{United Kingdom}

Donated US\$ 70000 to help fire victims, and provided two UNDAC members and one fire fighting expert, at a total cost of more than US\$ 140 000. Two Royal Air Force Canberras (3 crew and 40 support staff) equipped with IR detection systems were sent to Indonesia in early October to help trace the source of fires. However, the plan was cancelled because Indonesia reported it had made substantial progress in fighting the fires.

\section{United States}

Responded to the fires in October 1997 by sending three Hercules aircraft with fire fighting capabilities and 24 personnel to Indonesia. Fire fighting efforts were initially concentrated in East Java where water bombing was successful in extinguishing the fires; however, attempts at water bombing in Central Kalimantan were thwarted because of thick smoke. Efforts were then directed to South Sumatra, where the water bombing missions were effective in suppressing fires around settlements and in Way Kambas National Park. Suppressing the fires completely was difficult, especially in peat areas (Melnyk 1997a). The water bombing mission lasted from 21 October-4 December, and it was reported by the United Nations (1997) that US fire fighting efforts had cost US\$ 5 million.

Technical assistance was also provided for humanitarian relief, monitoring air quality and health and weather forecasting. Satellite data on active fire areas was provided on a daily basis to BAPEDAL from the US Forest Service (also was available on the Internet at $h t t p: / / w w w . f$ s.fed.us/eng/indofire). 


\section{Summary of Fire Projects}

The preceding six chapters have described in detail the objectives and activities of at least 35 projects, training courses and missions that have addressed or will address the issue of forest and land fires in Indonesia. This is not a definitive list, but is close to being so. In an attempt to understand the significance of these projects in the context of Indonesian fires since 1982-83 and to provide the reader with a summary, this chapter presents and discusses a basic synthesis of the projects.

\subsection{Temporal trends in fire projects}

Fire projects are precipitated by extreme fire events. It appears that if there is not an obvious problem then there is, in theory, no reason to start a project to study it. Extensive fires, transnational smoke haze, economic losses and severe health problems certainly grab attention and strongly suggest a problem. A repetition or exacerbation of the problem also increases the likelihood of attention.

Figure 3 attempts to illustrate the temporal pattern of fire projects in relation to extreme fire events. The first land and forest fires in Indonesia to capture international attention in recent times were the 1982-83 fires that broke out in East Kalimantan. The immediate follow-up in terms of international fire projects was small. GTZ carried out a short assessment in 1983 and a one-year assessment in 1988-89. This led to the strong presence of GTZ fire expertise in East Kalimantan, and GTZ was already well-established during the fire events of 1994 and 1997-98.

Between the 1982-83 and 1987 fires, there was comparatively little international involvement in addressing the Indonesian fire problem. This may to some extent be attributed to a lack of interest on the part of donors and international organisations. The Government of Indonesia itself may have considered the 1982-83 a one-time occurrence and did not encourage assistance from overseas. Following the fires in 1991, which also coincided with an ENSO event, there was a spate of shortterm interest and some of a long-term nature. Most of the short-term input came from missions making recommendations for prevention, suppression, control and management of fires. Few projects looked at the underlying causes of the fires. Some of these missions paved the way for the long-term fire projects of the EU, GTZ and JICA. In 1992, the Indonesian Government invited donors to a workshop addressing the fire problem from a prevention and management perspective.

The 1994 event was significant and 'major' in that the haze generated created transboundary effects in neighbouring countries. This led to questions concerning the cause of the fires, and blame was variously attributed to shifting cultivators and commercial companies. This was the first indication that the fire problem was more than just a climate-induced event and more intrinsically related to land use changes and tenure issues.

The majority of projects after 1994 address both the issues of causation and fire prevention and control. Unlike in previous years, several long-term projects were already operational by the time the 1997 fires started. Mechanisms for monitoring the fires, such as NOAA systems, were already in place. Figure 3 shows the comparatively large number of projects generated in response to the 1997-98 fires, this does not include all the missions and relief assistance described in Chapter 7 of this report. 
Figure 3. Temporal pattern of fire projects between 1982 and 1998

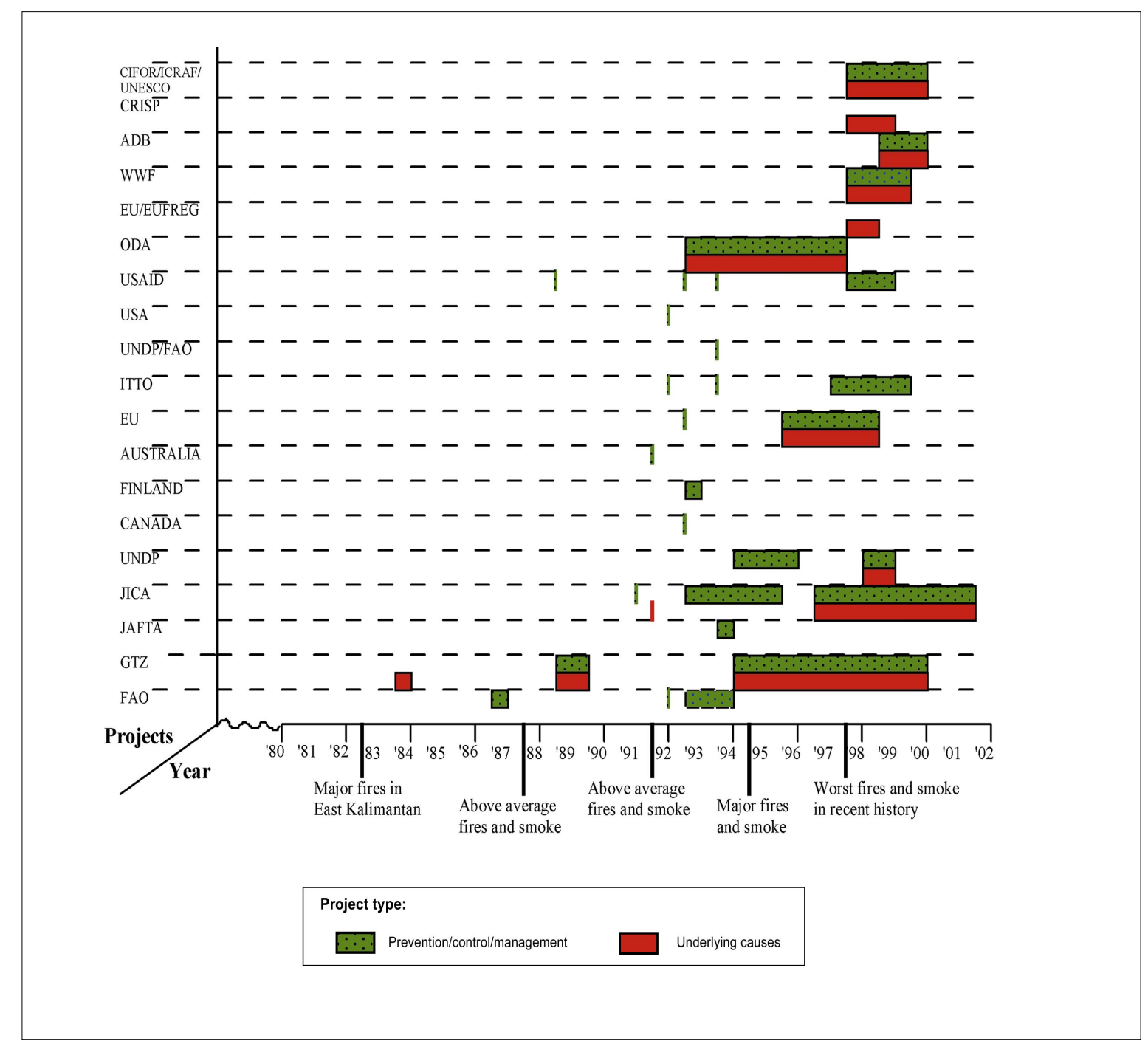

\subsection{General trends in Fire Project Objectives}

The main objectives of the fire projects can be classified into two distinct categories. First, there are those aimed at acquiring a better understanding the problem, e.g., identifying the underlying causes and impacts of forest and land fires, or estimating the burnt area. Secondly, there are projects that attempt to do something practical about the problem such as fire prevention, control and management.
The projects can be broadly categorised according to these two approaches (Table 7). Of the 35 projects, missions and training courses, 6 are mainly directed at trying to understand the problem, 19 are doing something practical about the problem, and 10 address both issues.

Based on the above classification, an assessment of the different types of activities addressed by the main fire projects during 1997-98 is given in Table 8 . Objectives 1-7 appear to be the 
Table 7. Summary of fire projects according to two main approaches of understanding the underlying causes $(A)$ and practical solutions through fire prevention, management and control $(B)$

\begin{tabular}{|c|c|c|c|c|c|}
\hline No & Project $^{a}$ & Title & Duration & $A^{b}$ & $B^{c}$ \\
\hline 1 & FAO (2.1.1) & Forest Fire Management & May 1992-Dec. 1993 & & $\checkmark$ \\
\hline 2 & GTZ (2.1.2a) & Assessment of $1982-83$ Fires & Oct. 1983 (5 weeks) & $\checkmark$ & \\
\hline 3 & GTZ (2.1.2b) & $\begin{array}{l}\text { Steps Needed to Rehabilitate } \\
\text { Areas of } 1982-83 \text { Fires }\end{array}$ & Oct. 1988-Sept 1989 & $\checkmark$ & $\checkmark$ \\
\hline 4 & JAFTA (2.1.3a) & $\begin{array}{l}\text { Study of Technologv for } \\
\text { Rehabilitation of Forest }\end{array}$ & Sept. 1993 (2 weeks) & & $\boldsymbol{V}$ \\
\hline 5 & JICA (2.1.3b) & Forest Fire Prevention & April 1993-April 1995 & & $\checkmark$ \\
\hline 6 & UNDP (2.1.4) & Forest Fire Management & 1994 (1 year) & & $\checkmark$ \\
\hline 7 & CANADA (2.2.1) & $\begin{array}{l}\text { Seminar - Forest Fire } \\
\text { Suppression }\end{array}$ & May 1992 & & $\boldsymbol{v}$ \\
\hline 8 & FINLAND (2.2.2) & Seminar - Forest Fire Control & Aug.-Sept. 1992 (4 weeks) & & $\checkmark$ \\
\hline 9 & AUSTRALIA (2.3.1) & $\begin{array}{l}\text { Mission - Assessment of fires } \\
\text { in } 1991\end{array}$ & October 1991 (1 week) & & $\checkmark$ \\
\hline 10 & EU (2.3.2) & Mission - Fire Protection & June-July 1992 (1 week) & & $\checkmark$ \\
\hline 11 & FAO (2.3.3a) & $\begin{array}{l}\text { Mission - Forest Fire } \\
\text { Prevention and Control }\end{array}$ & July-October 1986 & & $\checkmark$ \\
\hline 12 & FAO (2.3.3b) & $\begin{array}{l}\text { Mission - Forest Fire } \\
\text { Management }\end{array}$ & December 1991 (10 days) & & $\boldsymbol{V}$ \\
\hline 13 & ITTO (2.3.4a) & $\begin{array}{l}\text { Mission - Protection of } \\
\text { Tropical Forests against Fire }\end{array}$ & Jan.-Feb. 1992 (2 weeks) & & $\checkmark$ \\
\hline 14 & ITTO (2.3.4b) & $\begin{array}{l}\text { Mission - Establishment of } \\
\text { Demo Plots for Rehabilitation } \\
\text { of Forest }\end{array}$ & June 1993 & & $\checkmark$ \\
\hline 15 & JICA (2.3.5a) & $\begin{array}{l}\text { Mission - Fact Finding in E. } \\
\text { Kalimantan and S. Sulawesi }\end{array}$ & Nov.-Dec. 1991 (2 weeks) & $\checkmark$ & \\
\hline 16 & JICA (2.3.5b) & $\begin{array}{l}\text { Provision of Fire Fighting } \\
\text { Equipment }\end{array}$ & February 1991 & & $\checkmark$ \\
\hline 17 & UNDP/FAO (2.3.6) & $\begin{array}{l}\text { Mission - Forest Fire } \\
\text { Management }\end{array}$ & April-May 1993 & & $\checkmark$ \\
\hline 18 & USA (2.3.7) & Mission - Fire Assessment & Oct.-Nov. 1991(2 weeks) & & $\checkmark$ \\
\hline 19 & USAID (2.4.1a) & Training Course & August 1988 (2weeks) & & $\checkmark$ \\
\hline 20 & USAID (2.4.1b) & Training Course & July-Aug 1992 (2 weeks) & & $\checkmark$ \\
\hline 21 & USAID (2.4.1c) & Training Course & July 1993 (2 weeks) & & $\checkmark$ \\
\hline 22 & EU (3.1) & FFPCP & April 1995-1998 (3 years) & $\checkmark$ & $\checkmark$ \\
\hline 23 & GTZ (3.2) & IFFM & April 1994-2000 (6+ years) & $\checkmark$ & $\checkmark$ \\
\hline 24 & JICA (3.3) & FFPMP & April 1996-2001 (5 years) & $\checkmark$ & $\checkmark$ \\
\hline 25 & ODA (3.4) & ITFMP & April 1992-1997 (5 years) & $\checkmark$ & $\checkmark$ \\
\hline
\end{tabular}


Table 7. (continued) Summary of fire projects according to two main approaches of understanding the underlying causes $(A)$ and practical solutions through fire prevention, management and control $(B)$

\begin{tabular}{|c|c|c|c|c|c|}
\hline No & Project $^{a}$ & Title & Duration & $A^{b}$ & $B^{c}$ \\
\hline 26 & EU (4.1) & EUFREG & $\begin{array}{l}\text { Oct. 1997-May } 1998 \\
\text { (8 months) }\end{array}$ & $\checkmark$ & \\
\hline 27 & WWF (4.2) & Analysis of Causes and Impact & Oct. 1997-1998 (1+ years) & $\checkmark$ & $\boldsymbol{v}$ \\
\hline 28 & ADB (4.3) & RETA & April 1998-1999 & 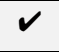 & $v$ \\
\hline 29 & ADB (4.4) & ADTA & June 1998-May 1999 & $\checkmark$ & $\checkmark$ \\
\hline 30 & $\begin{array}{l}\text { UNDP/State Ministry } \\
\text { of Environment (4.5) }\end{array}$ & $\begin{array}{l}\text { Environment Emergency } \\
\text { Project }\end{array}$ & Dec. 1997-May 1998 & $\checkmark$ & $\boldsymbol{v}$ \\
\hline 31 & ITTO (4.6) & $\begin{array}{l}\text { Guidelines - Protection of } \\
\text { Forest Against Fires }\end{array}$ & $1997-?$ & & $\boldsymbol{V}$ \\
\hline 32 & USAID (4.7.1) & $\begin{array}{l}\text { Assessment of Land and } \\
\text { Forest Fire Situation }\end{array}$ & Oct. 1997-April 1998 & $\checkmark$ & \\
\hline 33 & CRISP(4.7.2) & $\begin{array}{l}\text { Burnt Area Estimation/Satellite } \\
\text { Image Monitoring }\end{array}$ & September 1997 - ? & $\checkmark$ & \\
\hline 34 & SEAFIRE (4.7.3) & Impact of Fire Emissions & $1997-?$ & $\checkmark$ & \\
\hline 35 & $\begin{array}{l}\text { CIFOR/ICRAF/UNE } \\
\text { SCO (5.1) }\end{array}$ & $\begin{array}{l}\text { Underlying Causes and } \\
\text { Impacts of Fires }\end{array}$ & October 1997-2000 & $\checkmark$ & $\checkmark$ \\
\hline
\end{tabular}

Notes: ${ }^{\text {a. }}$ Number in brackets is the section in the report where this project is described; ${ }^{b}$. $A=$ Understanding the underlying causes of the fire problem; ${ }^{c} \mathrm{~B}=$ Practical approaches through fire prevention, control and management.

main types of activities chosen to understand the problem, and 8-14 are those activities that deal with the fires on a practical level.

\subsection{A comparison of the Long-Term Fire Projects}

Most of the projects in 1997-98 address efforts to understand the fires as well as fire prevention, control and management (Table 8). However, the three long-term projects (EU-FFPCP, GTZ-IFFM and JICA-FFPMP) focus mainly on activities such as fire prevention and control, NOAA fire hot spot detection, early warning systems and the institutional aspects of these activities. These projects all look at the underlying causes of the fires in specific provinces, but do not have an emphasis on historic, economic or ecological assessments. Although these projects address the underlying causes there seems (from project documents) to be a lack of focus on the impacts of fires on local livelihoods an ecosystems.
In many respects, these long-term projects are fairly similar in scope. This similarity to some extent maybe related to the fact that the projects were all the outcome of the conference on integrated fire management held in June 1992 (see Chapter $3)$. The conference identified that the core problem was that no fire management system existed. Understanding the causes and impacts of the problem did not seem to be high on the agenda at that time. It is interesting to note, however, that the three projects now include activities that investigate the causes. The following statement from a description of the EC-Indonesia Forest Programme seems to substantiate this theory. 'The original intention of the project was simply to help upgrade the Indonesian fire fighting capacity. However, it became clear during appraisal that further work had to be done on the causes of the fires and the local system for conflict resolution, before installing new capacity.' 
Table 8. Ongoing and new fire projects and their main objectives

\begin{tabular}{|c|c|c|c|c|c|c|c|c|c|c|c|}
\hline PROJECT & $\begin{array}{c}\text { EU- } \\
\text { FFPCP } \\
\text { (Section } \\
3.1 \text { ) }\end{array}$ & $\begin{array}{l}\text { GTZ-IFFM } \\
\text { (Section } \\
3.2 \text { ) }\end{array}$ & $\begin{array}{l}\text { JICA- } \\
\text { FFPMP } \\
\text { (Section } \\
3.3 \text { ) }\end{array}$ & $\begin{array}{c}\text { EUFREG } \\
\text { (Section } \\
4.1 \text { ) }\end{array}$ & $\begin{array}{l}\text { WWF } \\
\text { Indonesia } \\
\text { (Section } \\
4.2 \text { ) }\end{array}$ & $\begin{array}{c}\text { ADB- } \\
\text { RETA } \\
\text { (Section } \\
4.3 \text { ) }\end{array}$ & $\begin{array}{c}\text { ADB-ADTA } \\
\text { (Section } \\
\text { 4.4) }\end{array}$ & $\begin{array}{l}\text { UNDP/ } \\
\text { MoE } \\
\text { (Section } \\
4.5)\end{array}$ & $\begin{array}{l}\text { CRISP } \\
\text { (Section } \\
4.8)\end{array}$ & $\begin{array}{c}\text { SEAFIRE } \\
\text { (Section } \\
4.9)\end{array}$ & $\begin{array}{l}\text { CIFOR/ } \\
\text { ICRAF/ } \\
\text { UNESCO } \\
\text { (Section } \\
5.1 \text { ) }\end{array}$ \\
\hline Objectives & & & & & & & & & & & \\
\hline $\begin{array}{l}\text { 1. Assessment } \\
\text { of Underlying } \\
\text { Causes of Fire }\end{array}$ & $\begin{array}{c}\checkmark \\
\text { Southern } \\
\text { Sumatra }\end{array}$ & $\begin{array}{c}\checkmark \\
\text { East } \\
\text { Kalimantan }\end{array}$ & $\begin{array}{c}\checkmark \\
\text { Jambi, } \\
\text { West } \\
\text { Kalimantan }\end{array}$ & & $\begin{array}{l}+ \text { impacts } \\
\text { Sumatra, } \\
\text { Kalimantan }\end{array}$ & $\begin{array}{c}\checkmark \\
\text { brief } \\
\text { report }\end{array}$ & $\begin{array}{c}+ \text { impacts } \\
\checkmark \\
\text { East } \\
\text { Kalimantan, } \\
\text { Riau } \\
\end{array}$ & & & & $\begin{array}{l}+ \text { impacts } \\
\text { Sumatra, } \\
\text { Kalimantan }\end{array}$ \\
\hline $\begin{array}{l}\text { 2. Burnt Area } \\
\text { Estimation } \\
(1997-98)\end{array}$ & & $\begin{array}{c}\checkmark \\
\text { E. } \\
\text { Kalimantan }\end{array}$ & & $\begin{array}{c}\mathcal{v} \\
\text { Sumatra, } \\
\text { Kalimantan }\end{array}$ & $\begin{array}{c}\mathcal{v} \\
\text { Sumatra, } \\
\text { Kalimantan }\end{array}$ & & $\checkmark$ & & $\begin{array}{c}\mathcal{v} \\
\text { Sumatra, } \\
\text { Kalimantan }\end{array}$ & & $\begin{array}{c}\checkmark \\
\text { Sumatra, } \\
\text { Kalimantan }\end{array}$ \\
\hline $\begin{array}{l}\text { 3. Historic } \\
\text { Assessment of } \\
\text { Fires }\end{array}$ & & & & & & $\begin{array}{c}\boldsymbol{V} \\
\text { brief } \\
\text { report }\end{array}$ & & $\begin{array}{c}\boldsymbol{V} \\
\text { brief } \\
\text { report } \\
1982-97\end{array}$ & & & $\begin{array}{c}\boldsymbol{\checkmark} \\
\text { remote } \\
\text { sensing, } \\
\text { interviews, } \\
\text { literature }\end{array}$ \\
\hline $\begin{array}{l}\text { 4.Policy } \\
\text { Assessment }\end{array}$ & $\checkmark$ & $\checkmark$ & & & $V$ & $\begin{array}{c}\checkmark \\
\text { regional } \\
\text { review }\end{array}$ & $V$ & $V$ & & & 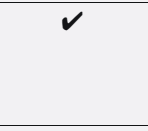 \\
\hline $\begin{array}{l}\text { 5. Economic } \\
\text { Assessment }\end{array}$ & & & & & $\checkmark$ & & $\checkmark$ & 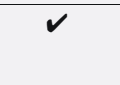 & & & $\begin{array}{c}\boldsymbol{V} \\
\text { local-level }\end{array}$ \\
\hline $\begin{array}{l}\text { 6. Ecological/ } \\
\text { Biodiversity } \\
\text { Assessment }\end{array}$ & & & & & $V$ & & $\checkmark$ & & & & \\
\hline $\begin{array}{l}\text { 7. Climatic } \\
\text { Factors }\end{array}$ & & & & & & & $V$ & & & $\checkmark$ & \\
\hline $\begin{array}{l}\text { 8. Fire } \\
\text { Prevention, } \\
\text { Control and } \\
\text { Training }\end{array}$ & $\begin{array}{c} \\
\text { provincial- } \\
\text { level }\end{array}$ & $\begin{array}{c}\boldsymbol{\checkmark} \\
\text { provincial- } \\
\text { level }\end{array}$ & $\begin{array}{c} \\
\text { provincial- } \\
\text { level }\end{array}$ & & & $\begin{array}{c}\boldsymbol{\checkmark} \\
\text { regional }\end{array}$ & $\checkmark$ & $\begin{array}{c}\boldsymbol{v} \\
\text { review }\end{array}$ & & & $\begin{array}{c}\boldsymbol{\checkmark} \\
\text { community- } \\
\text { level }\end{array}$ \\
\hline
\end{tabular}


Table 8. (continued) Ongoing and new fire projects and their main objectives

\begin{tabular}{|c|c|c|c|c|c|c|c|c|c|c|c|}
\hline PROJECT & $\begin{array}{l}\text { EU- } \\
\text { FFPCP } \\
\text { (Section } \\
3.1 \text { ) }\end{array}$ & $\begin{array}{l}\text { GTZ-IFFM } \\
\text { (Section } \\
3.2 \text { ) }\end{array}$ & $\begin{array}{l}\text { JICA- } \\
\text { FFPMP } \\
\text { (Section } \\
\text { 3.3) }\end{array}$ & $\begin{array}{c}\text { EUFREG } \\
\text { (Section } \\
4.1)\end{array}$ & $\begin{array}{l}\text { WWF } \\
\text { Indonesia } \\
\text { (Section } \\
\text { 4.2) }\end{array}$ & $\begin{array}{l}\text { ADB- } \\
\text { RETA } \\
\text { (Section } \\
4.3 \text { ) }\end{array}$ & $\begin{array}{l}\text { ADB- } \\
\text { ADTA } \\
\text { (Section } \\
4.4)\end{array}$ & $\begin{array}{l}\text { UNDP/ } \\
\text { MoE } \\
\text { (Section } \\
4.5 \text { ) }\end{array}$ & $\begin{array}{l}\text { CRISP } \\
\text { (Section } \\
4.7 .2 \text { ) }\end{array}$ & $\begin{array}{l}\text { SEAFIRE } \\
\text { (Section } \\
\text { 4.7.3.) }\end{array}$ & $\begin{array}{c}\text { CIFOR/ } \\
\text { ICRAF/ } \\
\text { UNESCO } \\
\text { (Section } \\
5.1 \text { ) }\end{array}$ \\
\hline Objectives & \multirow[b]{2}{*}{$\checkmark$} & \multirow[b]{2}{*}{$\checkmark$} & \multirow[b]{2}{*}{$\checkmark$} & & & & & & & & \\
\hline $\begin{array}{l}\text { 9. NOAA Fire Hot } \\
\text { Spot Detection }\end{array}$ & & & & & & & & & & & \\
\hline $\begin{array}{l}\text { 10. Alternatives to } \\
\text { Burning }\end{array}$ & $\checkmark$ & & & & $\checkmark$ & & $\nu$ & & & & $\checkmark$ \\
\hline $\begin{array}{l}\text { 11. EWS } \\
\text { Development. and } \\
\text { Research }\end{array}$ & $\checkmark$ & $\checkmark$ & $v$ & & & $\begin{array}{l}\checkmark \\
\text { regional } \\
\text { review }\end{array}$ & $\begin{array}{c}\boldsymbol{V} \\
\text { review }\end{array}$ & $\begin{array}{c}\boldsymbol{V} \\
\text { review }\end{array}$ & & & \\
\hline $\begin{array}{l}\text { 12. Institutional } \\
\text { Aspects of Fire } \\
\text { Management }\end{array}$ & $\checkmark$ & $\checkmark$ & $\checkmark$ & & & & $\checkmark$ & $\checkmark$ & & & $\checkmark$ \\
\hline $\begin{array}{l}\text { 13. Atmospheric } \\
\text { Pollution }\end{array}$ & & & & & & $\checkmark$ & & & & $\checkmark$ & \\
\hline $\begin{array}{l}\text { 14. Transboundary } \\
\text { Initiatives }\end{array}$ & & & & & & $\begin{array}{c}\boldsymbol{\checkmark} \\
\text { action } \\
\text { plan }\end{array}$ & & & & \begin{tabular}{c}
\multicolumn{1}{c}{} \\
biomass \\
burning
\end{tabular} & $\begin{array}{c}\text { biomass } \\
\text { burning }\end{array}$ \\
\hline
\end{tabular}




\subsection{A comparison of the New Generation of Fire Projects}

The majority of fire projects that have arisen from the ashes of the 1997-8 fires have a balance of activities, with perhaps a slight tendency to look more at understanding the root causes and impacts of the problem. The WWF project is a good example of one of the new projects. It got under way while the fires were still blazing in 1997 and was to last for a minimum of one year. The project addressed important issues, such as the underlying causes, policy, economic losses and ecological impacts as well as burnt area estimation, but only one aspect of fire prevention (alternatives to burning). The project has produced many useful reports in a short time, but is also in the difficult situation of addressing complex issues within a short time frame. The importance of publicising findings while the fires are still fresh is people's minds cannot be understated. The balance between releasing results and recommending solutions quickly and spending sufficient time finding the answers is an important consideration. It is hoped this project will continue into second and third years.

Some of the shorter term projects started producing final reports towards the end of 1998 and beginning of 1999. These reports provide valuable insights into the social/ environmental impacts and policy/institutional implications (State Ministry of Environment/UNDP 1998; ADB 1999). As can be seen from Table 8 these projects encompass many of the objectives identified as those important to understanding and preventing fires. Although these projects are broad in scope and relatively short in time they represent an important and timely source for policy makers and the longer-term projects.

At the other end of the spectrum, the CIFOR/ ICRAF/UNESCO research project proposes to focus on an in-depth understanding of the causes and impacts of fires in the past and present. The minimum time period for this research is three years. By its nature, this approach will not produce definitive answers in the first or second years, but only after three years of thorough research. The final results of the in-depth research will be channelled into policy recommendations only after this period. In the meantime, policy makers need some interim guidance. Collaboration between research projects such as the CIFOR/ICRAF/ UNESCO consortium and the more applied approach of WWF will be important to achieve this aim.

\subsection{Is overlap a bad thing?}

One immediately observable trend (Table 8) is overlap between projects in terms of objectives. Of the 11 projects, eight assess the underlying causes of fire. Only four assess the impact as well. However, of these eight, five look specifically at one or several provinces, two at the whole of Sumatra and Kalimantan and at detailed sites in several provinces, and the remaining project is general in scope. In this case, overlap is not necessarily counterproductive, assuming that there is close collaboration and sharing of results among projects.

The new generation of projects overlap, but in different ways. Some are short-term (up to a year) and others are longer-term (up to 3 years). Constrained by time, some of the projects adopt a fairly general approach while others are more indepth and research-oriented. The geographical areas selected for detailed assessments vary, although all concentrate on Kalimantan or Sumatra. The lesson to be learned from the degree of overlap between projects is that cooperation, openness and dissemination of results among projects and the relevant government departments is of paramount importance. In practice, this could take the form of a consultative group on forest and land fires that meets every six months.

One area of concern is the number of projects attempting to produce estimates of the burnt area. This is a lengthy process, and slightly different methodologies and classification criteria will lead 
to different results and confusion for the end user of such data. Six of the 11 projects are providing burnt area estimates. GTZ will only provide these for East Kalimantan; the other projects will provide estimates for Sumatra and Kalimantan, and in some cases possibly Indonesia as whole. The projects are all using slightly different methodologies. Results are already emerging, and in some cases estimates vary. It is important that there be an agreed burnt area estimate and burnt area maps for 1997-98. Much of the analysis planned by various projects will rely on these figures, and the use of a common estimate will make results readily comparable. The CIFOR/ICRAF/UNESCO project intends to compile as much of the data produced by the other projects in its analysis of burnt areas.

\subsection{Conclusion}

Of all the Indonesian fire events to date, the 1997-98 episode has captured the most global attention. There is no denying that this was a large fire event in terms not only of the area burnt and the amount of smoke haze produced but also the economic and health effects. In addition, the media coverage of the fires was immense. For a few months in 1997 and 1998, it was a global environmental issue. The Internet also played a part. As Appendix 2 shows, a vast amount of information was available about the fires on a daily basis, the majority from Web sites outside Indonesia. The economic crisis experienced by Indonesia simultaneously most likely increased the country's reliance on outside help.

The experience of the past shows that interest wanes not long after a major fire, although it would seem hard to forget the latest fires. It is hoped that the interest and financial commitment of donors will be maintained in coming years. The experience of 1997-98 has clearly shown that important questions still remain unanswered in the complex fire problem. The new generation of projects offers some hope that these questions will be answered, and that a solution to Indonesia's fire disasters will one day be a reality. 


\section{Appendix 1. The use of NOAA-AVHRR Fire Monitoring Systems}

There are now six NOAA-AVHRR systems in operation in Indonesia. These systems are located in Bogor (JICA-FFPMP/PHPA); Palembang, South Sumatra (EU-FFPCP/Dinas Kehutanan); Samarinda, East Kalimantan (GTZ-IFFM/Dinas Kehutanan); Palangkaraya, Central Kalimantan (DFID-ITFMP/Dinas Kehutanan); Pekayon, Jakarta (LAPAN/BMG); and Jakarta, Jl. Thamrin (BPPT).

The first to be established was the station installed through the ITFMP in Central Kalimantan in September 1993; see section 3.4 (Schneider 1995). The MoF showed interest in the technology as early as 1990, when an assessment of the potential of NOAA satellite data for forest fire monitoring in Kalimantan and Sumatra was made by the Directorate General of Forest Inventory and Land Use (INTAG 1991). This study examined three aspects of fire monitoring using NOAA data:

- calculation of NDVI (a measure of photosynthetically active vegetation);

- determination of cloud cover; and

- detection of hot spots.

Unfortunately the use of wet-season imagery in the study meant that no fires were actually detected. However, the potential of NOAA data for providing up-to-date information that could be useful for determining fire risk was demonstrated.

\section{Problems with using hot spots}

Throughout the past year, the word fire 'hot spot' has been added to many peoples' vocabularies. There is no doubt that the benefits of using such a system for fire monitoring have become clear in many minds. However, some problems have emerged in understanding the data and a number of projects are assessing the accuracy of the hot spot data generated in 1997. Misuse of hot spot information can result in considerable confusion, as was shown by the widely varying estimates of hot spots.

The method of deriving hot spots from AVHRR imagery is still at a relatively early stage of development. The AVHRR scanner was designed to measure surface temperature of large relatively uniform surfaces such as oceans and the tops of clouds. As neither is very hot the sensor was optimised for lower temperatures $\left(<40^{\circ} \mathrm{C}\right)$. The sensor measures average temperature for a minimum ground area of $1 \mathrm{~km}$ by $1 \mathrm{~km}$ (spatial resolution of the sensor). A hot fire smaller than this size can be detected, as it will significantly raise the average temperature of a $1 \mathrm{~km}$ square ground area, but hot bare soil can have the same effect. The most reliable way to detect hot spots is to visually check the imagery for smoke plumes, burn scars and the evidence of previous days' fires. Such an approach is labour intensive but does result in more reliable hot spot information. Using night time AVHRR imagery in preference to day time imagery reduces bare soil effects. Various techniques have been and are being developed to deal with the effects of soil; one thresholds temperatures and only accepts the hottest hot spots; another calibrates for local vegetation and soil conditions; and, finally, contextual algorithms examine pixel values around possible fire pixels to assess probability (Flasse and Ceccato 1996).

A further problem with the hot spot maps is that an absence of hot spots does not mean an absence of fires. Thermal scanners cannot 'see through' clouds, haze and smoke. Therefore one must refer to the AVHRR images when viewing a hot spot map, as this will indicate where cloud or smoke is obscuring the ground. Most hot spot maps do not show the location of clouds as a guide for the 
interpreter; however, the GTZ hot spot maps do, which is of considerable help.

Finally, the geometric accuracy of the hot spot locations must be considered. The pixel resolution of AVHRR is $1 \mathrm{~km}$ square, and the accuracy of geometric correction of the imagery can be up to 2 pixels. This translates to a possible error of up to 2 $\mathrm{km}$ in the positioning of a hot spot from its true ground position. This also means that the same hot spot may not appear in the same position on consecutive images although it is the same fire.

Apart from technical advances, there is also scope for improvements and coordination in the way hot spot information is used. Wall (1997) and Legg (1997) have made a number of recommendations regarding the use of hot spot information.

\section{Processing of hot spots}

The JICA, EU and GTZ stations processed hot spots in slightly different ways. Data from the Palembang station was thresholded to high temperatures, retaining only the hottest pixels as possible fires. Contextual filtering was applied on some days, but not others. On very hot clear days there were more than 5000 hot spots recorded in Sumatra. The JICA/ PHPA station also experimented with temperature thresholding and contextual filtering. Preliminary comparison with burn scars on SPOT quicklooks suggests that less than $25 \%$ of the hot spots actually indicated fires (Legg 1997).

The GTZ station appears to have had the most rigorous screening of hot spots developed for conditions in Kalimantan. For each spot details of surface reflectance (albedo) in the visible and infrared bands were provided, together with temperatures for two thermal channels, thus allowing ranking of hot spots. Since February 1998 daily (cloud and smoke cover permitting) hot spot maps are provided on the IFFM home page (http:/ /www.iffm.or.id). Map 2 is an example of a hot spot map downloaded from the IFFM Web site.

The JICA Fire Project, based in Bogor, produced daily hot spot maps throughout the 1997 and 1998 fires. These hot spot maps were relayed directly to the Minister of Forestry; the maps were also displayed on the MoF Web site (http:// mofrinet.cbn.net.id/). Maps 3 and 4 show example of the fire hot spot maps.

Hot spot locations from LAPAN were relayed to the BAPEDAL Command Post for Fires (Posko Kebakaran) on a daily basis. From 19 September until the end of November, daily hot spot maps by province (Sumatra, Kalimanta, Java, Sulawesi, NTT and Bali) were available on the BAPEDAL Web site (http://www.bapedal.go.id/ poskodal/). However, the accuracy of the hot spot information has been questioned. It is reported that the hot spot information was generalised, leading to an underestimation. Map 5 is an example of a hot spot map downloaded from the BAPEDAL Web site.

\section{Improving the use of hot spot information}

At the national level, standardisation is desirable. This could be achieved through:

- controlled research to establish more clearly the best temperature threshold (for classification of hot spots), whether this should change as the ground temperature rises during the dry season, the different advantages of night and day time AVHRR imagery, and more field checks of hot spots; and

- standardisation of terminology and data presentation ('spots' or 'clusters', map scales, and most useful background map themes).

At the provincial level the use of AVHRR imagery and hot spots is severely restricted by:

- the lack of up-to-date and accurate baseline maps on land cover and land use/status (on what type of land - vegetation/ownership - the fires are occurring);

- the physical lack of a central, well-equipped provincial command centre - such a centre should take decisions on which hot spots/fires should be made priority; have province-wide maps on fire fighting capability, fire risk maps, and maps of infrastructure needed for fire fighting; and be 
equipped with good communication systems; and

- the lack of information flow to the district level. Although the term 'early warning' is used to describe many of the NOAA-AVHRR systems in place, few of them actually fill this role yet. At present, they report the occurrence of hot spots, which means fires are already burning. Research is still needed on vegetation and fuel types, high fire risk areas and changing vegetation conditions.

Map 2. Example of fire hot spot map from the IFFM web site

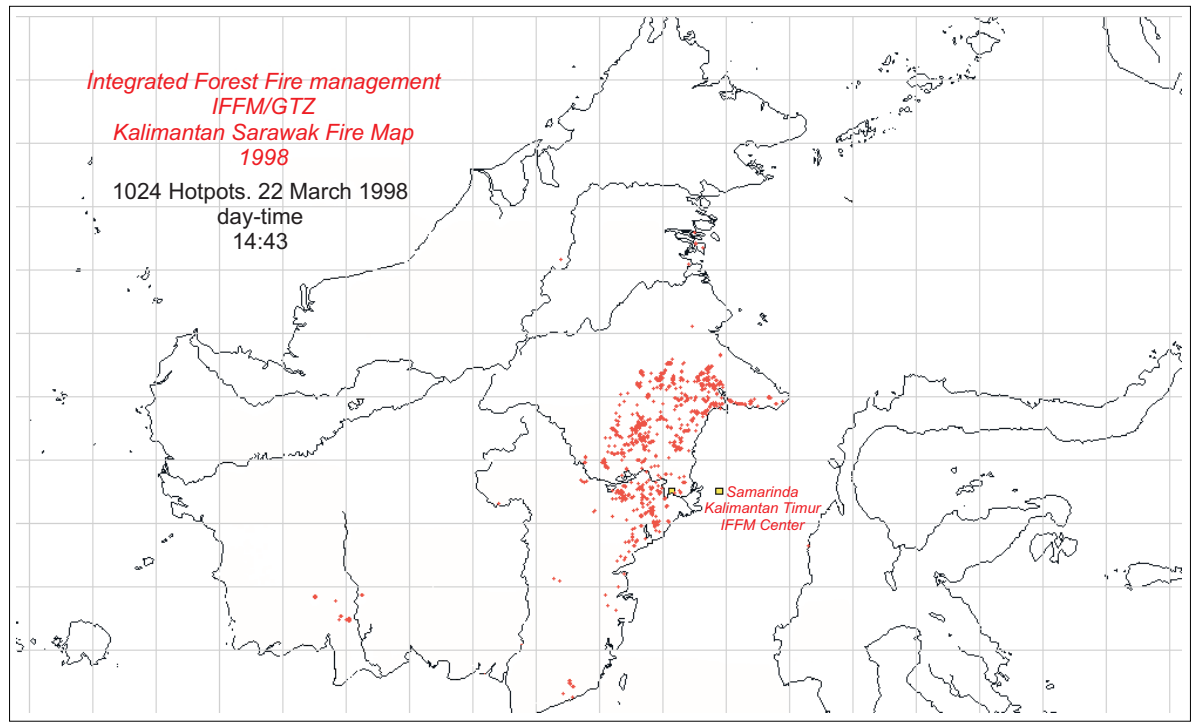

Map 3. Example of fire hot spot map from the JICA Fire Project, downloaded from the Ministry of Forestry web site

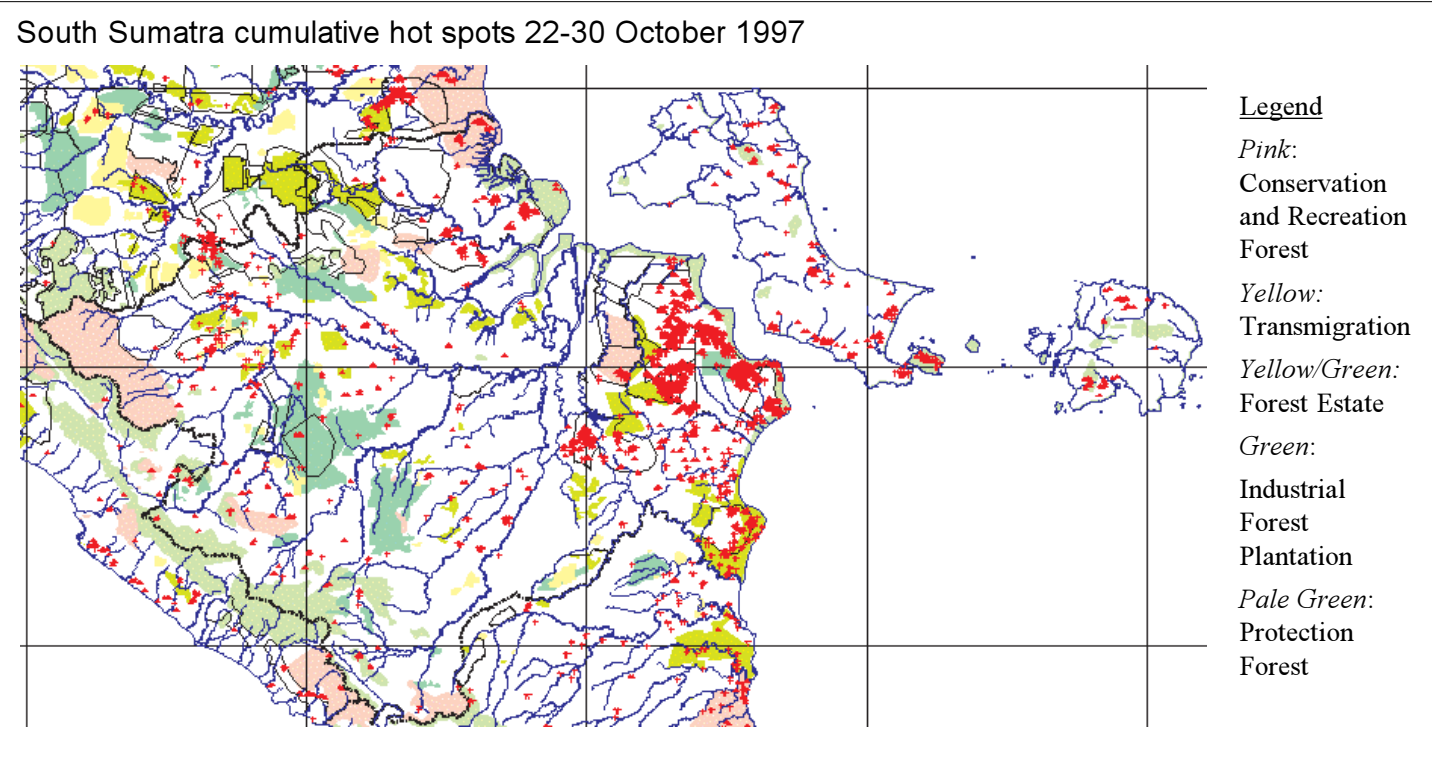


Map 4. Example of fire hot spot map from the JICA Fire Project, downloaded from the Ministry of Forestry web site

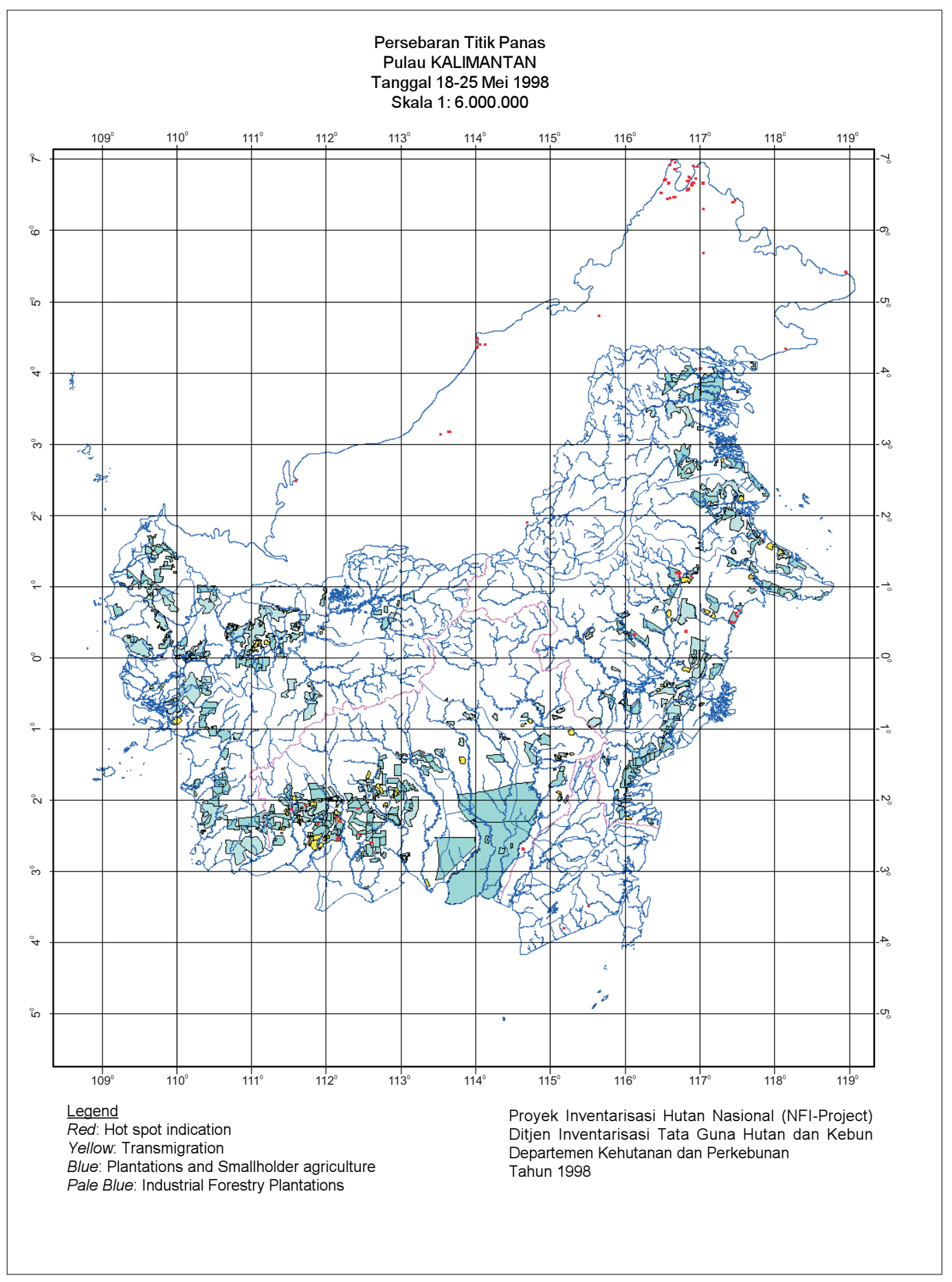


Map 5. Example of fire hot spot map from the BAPEDAL web site

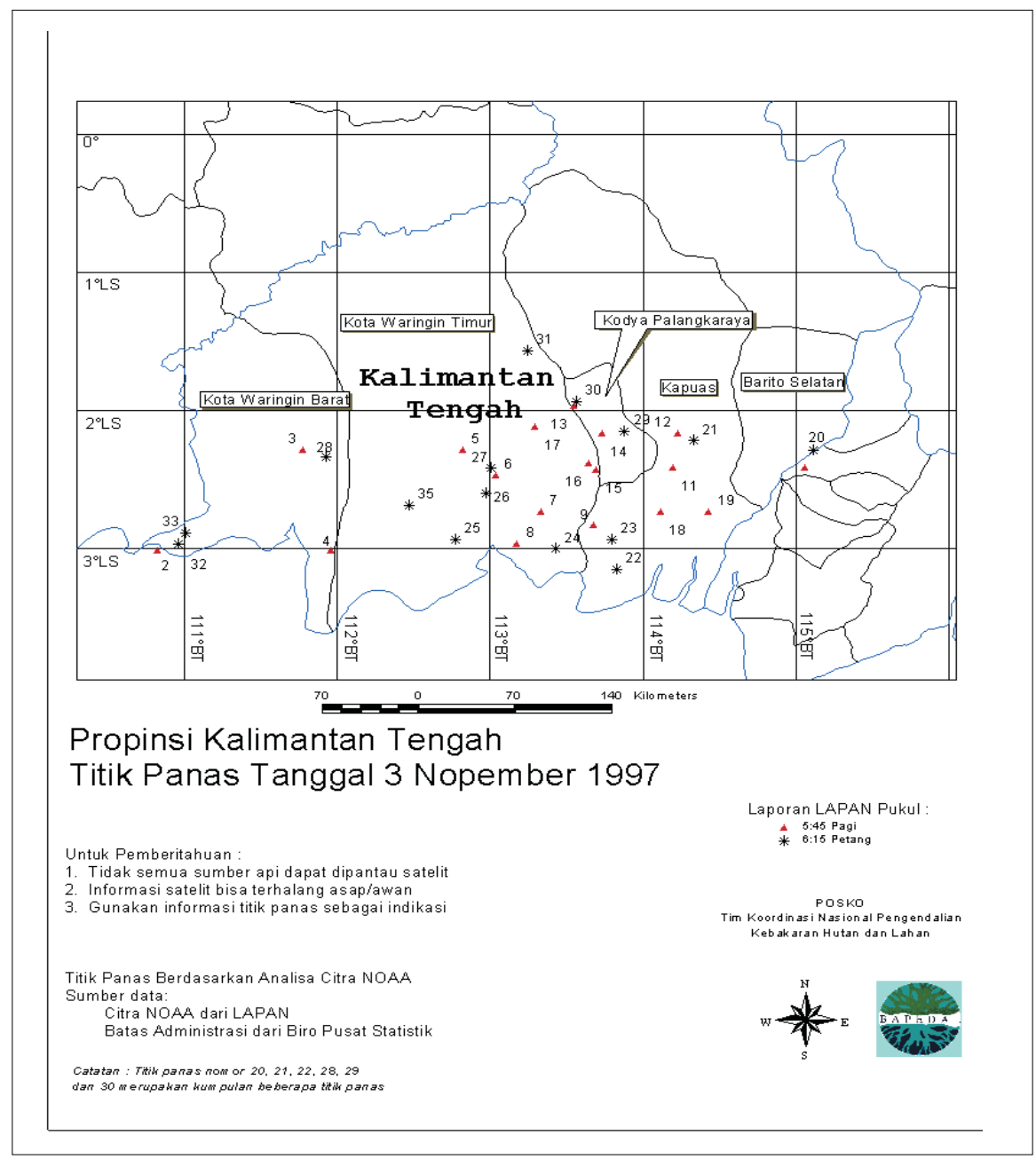




\section{Appendix 2. A Selection of Useful Web Sites Relating to the Fires and Smoke over Indonesia}

\section{Images and Hot Spot Maps}

\section{BAPEDAL}

http://www.bapedal.go.id

Throughout the 1997 period of fires in Indonesia, the Environmental Impact Management Agency (BAPEDAL) provided an up-to-date and evolving web site. The site provided information on the fire hot spot locations by province in Java, Sumatra, Kalimantan, Sulawesi, Bali, Nusa Tenggara and East Timor. This fire hot spot information is available only in the Indonesian version. The fire hot spot locations are interpreted from NOAA 14 imagery from LAPAN. In addition to hot spot maps, tables of hot spot locations in geographic coordinates are also provided. Hot spot maps were available for the period from mid-September to midNovember 1997. No maps were added in 1998.

\section{Meteorological Service Singapore http://www.gov.sg/metsin/}

The Meteorological Service under the Ministry of Communications of Singapore, provides a very comprehensive Web site. The section that relates to forest fires can be found under the section 'Haze Monitoring', then a subsection titled 'Monitoring of Widespread Smoke Haze and Forest Fires in the Region'. This section gives a general descriptive outlook for the area, visibility readings over Singapore and other cities in the region, latest pollutant standards index (PSI), effects on sea and air activities, GMS images in visible and infrared (as .GIF files), schematic of haze, and NOAA 14 AVHRR day time images with fire as red spots. NOAA AVHRR night time images are also available. The images and other information usually cover peninsular Malaysia, Sumatra, Kalimantan and Java. All information is updated daily. Examples of the output from this web site can be seen in Map 6 and 7 in Appendix 3.

\section{Centre for Remote Imaging, Sensing and Processing} http://www.crisp.nus.edu.sg

This is another Singapore Web site, in this case handled by the Centre for Remote Imaging Sensing and Processing of the National University of Singapore. This site provides database browsers for SPOT imagery and ERS and Radarsat radar imagery. During the forest fires, the site ran a special feature on 'SPOT Satellite Images of Forest/ Plantation Fires and Smoke/Haze over Southeast Asia'. Under this section, a selection of time-series SPOT imagery showing fire development in the following areas is available: near Banjarmasin, Kalimantan; Jambi, Sumatra; the southern part of West Kalimantan; near the Kapuas River in West Kalimantan; near Palembang, Sumatra; and finally over Brunei bay. New images were added during the 1998 fires, including images of East Kalimantan, Sabah, Sarawak and Brunei. An example of the output from this web site can be seen in Map 8, Appendix 3.

\section{National Oceanic and Atmospheric Administration of US Government}

http://www.goes.noaa.gov/SPECIAL/FIRES/ INDONESIA

now moved to http://oses1.wwb.noaa.gov/

The NOAA geostationary satellite web browser (now the Operational Significant Event Imagery Archive) provides a section on Indonesian fires (and 
other fires in the world). Almost daily, NOAA AVHRR imagery was provided as .GIF files for the 1997 and 1998 fires. Map 9, Appendix 3, is an example of the image output from this site.

\section{Indonesian Ministry of Forestry and Estate Crops}

http://mofrinet.cbn.net.id/e_informasi/e_nfi/ Mon_noaa.htm

The Indonesian version of the Ministry of Forestry Web site added a section on fires in October 1997. There was a general statement about fires in Kalimantan and Sumatra, followed by tables of information concerning areas of production forest that are to be converted to forest estates or transmigration sites. Distribution of fire hot spot information was found under the NOAA page. Here very detailed and complete information was available on fire hot spots in relation to protected areas, protection forest, concessions, plantations, forest estates and transmigration sites. The data come from the JICA Fire Project, located in DG PHPA, and uses NOAA and HIMAWARI satellite imagery to generate hot spot locations. Kalimantan and Sumatra are covered in great detail by province and island from August through to November 1997. The fire hot spot maps can be downloaded in GIF format. The site was updated in February 1998. Examples of maps from this site can be seen in Appendix 1, Maps 3 and 4.

\section{LAPAN}

http://www.lapan.go.id

The official web site for the Indonesian National Remote Sensing Centre carries pages with a selection of NOAA AVHRR imagery and predicted drought areas in Indonesia.

\section{Integrated Forest Fire Management Project}

http://www.iffm.or.id

This site started posting daily fire hot spot maps for Kalimantan in February 1998. The site also contains useful information on other topics related to the fires, such as fire danger ratings for East Kalimantan, fire situation reports and project activities. There are also links to related sites. Appendix 1, Map 2, is an example of an IFFM hot spot map for Kalimantan.

\section{Forest Fire Prevention and Control Project}

http://Www.mdp.co.id/ffpcp.htm

This site came online in 1998. Firstly, it contains a basic description of the project. Fire maps and hot spot coordinates for Sumatra and fire index maps of South Sumatra are posted on this site and regularly updated. There are also sections on coal and peat fires in Sumatra, fire fighting and first aid courses and fire prevention education programmes.

\section{USDA Forest Service}

http://www.fs.fed.us/eng/indofire

The products available on this site are described in Section 4.7.1 of the main report. The site contains maps of wildfires in Kalimantan and Sumatra from 21 October-30 November 1997 and 7 February-13 March 1998. Maps 10a and 10b, Appendix 3, are examples of fire maps from this web site.

\section{NASA Total Ozone Mapping Spectrometer (TOMS) Project}

http://jwocky.gsfc.nasa.gov/indonesia.html

This page is home for information, data and images for all of the Total Ozone Mapping Spectrometer (TOMS) instruments. NASA's TOMS instruments provide global measurements of total column ozone daily. This NASA site shows daily smoke concentration images for Indonesia between 3 September and 16 November 1997, and 6 February and 21 April 1998. Map 11, Appendix 3 is an example a smoke map. 


\section{European Space Agency/ESRIN}

http://earth1.esrin.esa.it/eeonline/eeo12

This Web site is provided by Eurimage and ESA/ ESRIN, which started the Earth Watching project to supply satellite data and pertinent information quickly in cases of natural disasters; and to demonstrate the benefits of remote sensing applications during emergencies, through images and articles. One of natural disasters featured on this page is the 'Fires and Smoke Haze on SouthEast Asia '97 and '98'. A number of images are shown; some are from the Along-Track Scanning Radiometer (ATSR) instrument and others from the Global Ozone Monitoring Experiment (GOME) spectrometer, all on board the ESA ERS-2 satellite. Buongiorno et al. (1997) provide a good description of the use of ATSR and GOME imagery for monitoring the fires in Southeast Asia. Antikidis et al. (1998) discuss the results of combining ATSR fire hot spots with ERS radar coherence images to classify areas of deforestation caused by fires in Central Kalimantan.

\section{UNEP-Global Resource Information Database (GRID)}

http://grid2.cr.usgs.gov/indofire/

UNEP-GRID has assembled satellite images from various sources and put them on them on this site.

\section{World Conservation Monitoring Centre (WCMC)}

http://www.wcmc.org.uk/emergency/

WCMC has compiled information on the natural ecosystems, biodiversity and protected areas affected by the fires in Indonesia.

\section{Thailand Remote Sensing Centre (TRSC)}

http://www.nrct.go.th/

A small selection of Landsat TM and NOAA images showing fires and smoke for September, October, and November 1997 were displayed on this web site. However, they are no longer available.

\section{Space Shuttle Images}

http://www.jpl.nasa.gov/releases/kidsatimages.html Images from the space shuttle of fires in Indonesia.

\section{Defense Meteorological Satellite Program (DMSP)}

http://ngdc.noaa.gov/dmsp/fires/indofires.html

The NOAA National Geophysical Data Center produced night time DMSP images over Indonesia during the 1997 fires.

\section{Others}

\section{Joint Research Centre of the EC} http://www.jrc.org/sai/mtv/activities/

This site gives information about the FIRE and TREES Project of the Monitoring Tropical Vegetation Unit of the Joint Research Centre of the European Commission.

\section{Indonesian Meteorological and Geophysical Agency (BMG)}

http://www.cbn.net.id/commerce/bmg/english

The Indonesian Meteorological and Geophysical Agency has some useful information on its web site pertaining to haze and current weather conditions.

\section{Singapore Straits Times}

http://straitstimes.asial.com

The Straits Times newspaper in Singapore has a haze watch page that carries news stories related to the forest fires, as well as samples of imagery and links to other associated web sites.

\section{CIFOR}

\section{http://www.cgiar.org/cifor}

The CIFOR web site contains statements on topical issues relating to forests in Indonesia. During the fires there was a statement on the forest and land fires, which was followed by a statement on the 'Indonesian Economic Crisis and its Impact on the Forest Sector: A CIFOR Perspective'. The site also 
contains useful information on workshops, conferences, publications and CIFOR News.

\section{UN OCHA}

http://www.reliefweb.int

ReliefWeb is the web site of UN OCHA. The site states that the purpose is 'to strengthen the response capacity of the humanitarian relief community through timely dissemination of reliable information on prevention, preparedness, and disaster response'. The site contains an archive of reports about disasters such as the Indonesian fires. There is also a useful collection of maps and links to other sites.

\section{Indonesia Nature Conservation Database} http://www.noord.bart.nl/ edcolijn/index.html

This privately run site contains a wealth of information on nature conservation in Indonesia. It includes detailed information on officially protected sites, and mammals, bird, reptile, amphibian and freshwater fish lists. There is also a weekly mailing list that contains a broad selection of news items and new information regarding environmental and conservation issues in Indonesia and Papua New Guinea.

\section{World Wide Fund for Nature}

http://www.worldwildlife.org/new/fire;

http://www.panda.org/news/press

These are general WWF Web sites, which contain information on the fires in Indonesia during 1997 and 1998.

\section{WWF Malaysia}

http://www.geocities.com/RainForest/2701/ haze.htm

This is the WWF Malaysia web site, and it contains an impressive amount of information regarding fires in Indonesia and Malaysia on its haze alert page.
The page contains WWF reports, papers, press releases and maps from WWF Malaysia, WWF Indonesia Programme and WWF International, links to other haze sites, and news archives for 1997 and 1998 .

\section{WWF Indonesia}

http://www.wwf.or .id

This web site has a section devoted to forest fires. Many of The Project reports are available in this site.

\section{ASEAN}

http://www.aseansec.org or http:// www.asean.or.id/

The ASEAN web site contains information about ASEAN, reports of meetings and ASEAN statements.

\section{TROPENBOS Foundation}

http://www.tropenbos.nl/tropenbos/firenews

The TROPENBOS site contains statement on the 1998 fires and useful links to other fire-related sites.

\section{HAZE}

http://www.geocities.com/HotSpring/2188/ haze.html

This site contains the most comprehensive selection of links to sites related to fires and smoke haze worldwide. The haze related sites fall under the following headings: situation over Southeast Asia, current situation, satellite images, news online, El Niño, La Niña, health and air pollution.

\section{BOSDATA}

http://www.bosdata.nl/fire/indo en/main.html

This is a Dutch site, with an English version, containing news archive stories on fires in Indonesia and Brazil, El Niño and orang utans. 


\section{Canadian Forest Service}

http://www.nofc.forestry.ca/fire/asean

The Canadian Forest Service has made a demonstration ASEAN Fire Weather Information System (AFWIS) available on its web site. The site shows up-to-date examples of AFWIS input maps (temperature, dew point, relative humidity, wind speed, wind direction, precipitation, days since rain, visibility) and output maps (fine fuel moisture code, duff moisture code, drought code, initial spread index, buildup index, fire weather index). An example of a precipitation map and a fire weather map can be seen in Appendix 3 (Maps 12a and 12b).

\section{Global Fire Monitoring Centre}

http://www.ruf.uni-freiburg. de/fireglobe/

The Global Fire Monitoring Centre (GFMC) was established in June 1998 at the Fire Ecology and Biomass Burning Research Group of the Max Planck Institute of Chemistry in Germany. The GFMC documents, archives, and provides information related to fire. The ADB's ASEAN Regional Technical Assistance Project on Mitigating Transboundary Pollution is linked to GFMC. This web site provides many useful links to other web sites including one to the UN International Forest Fire News (IFFN). 


\section{Appendix 3. Examples of Maps and Images of the 1997/98 Fires and Smoke}

Map 6. Example of Haze Map downloaded from the Meteorological Service Singapore web site.

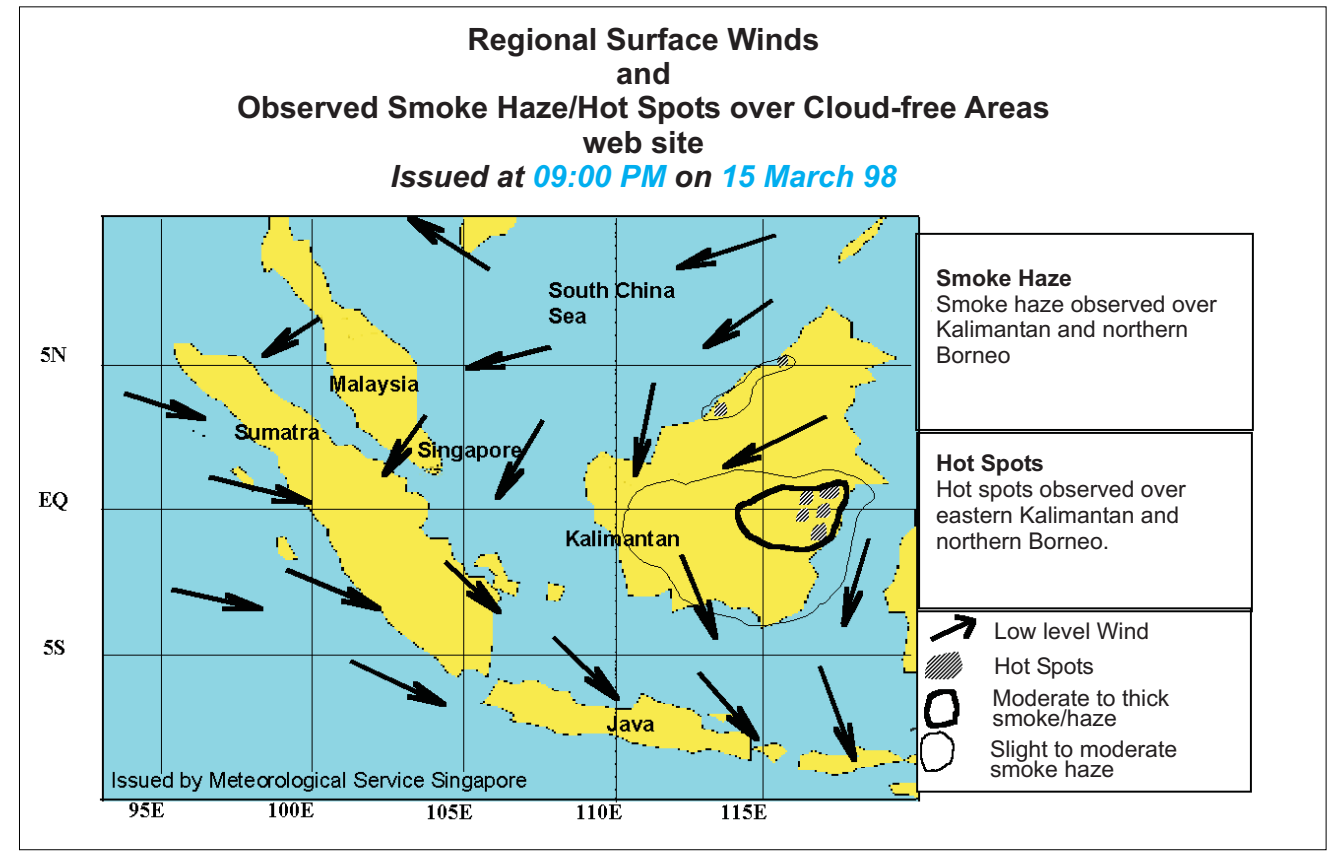


Map 7. Example of NOAA AVHRR image with fire hot spots downloaded from the Meteorological Service Singapore web site

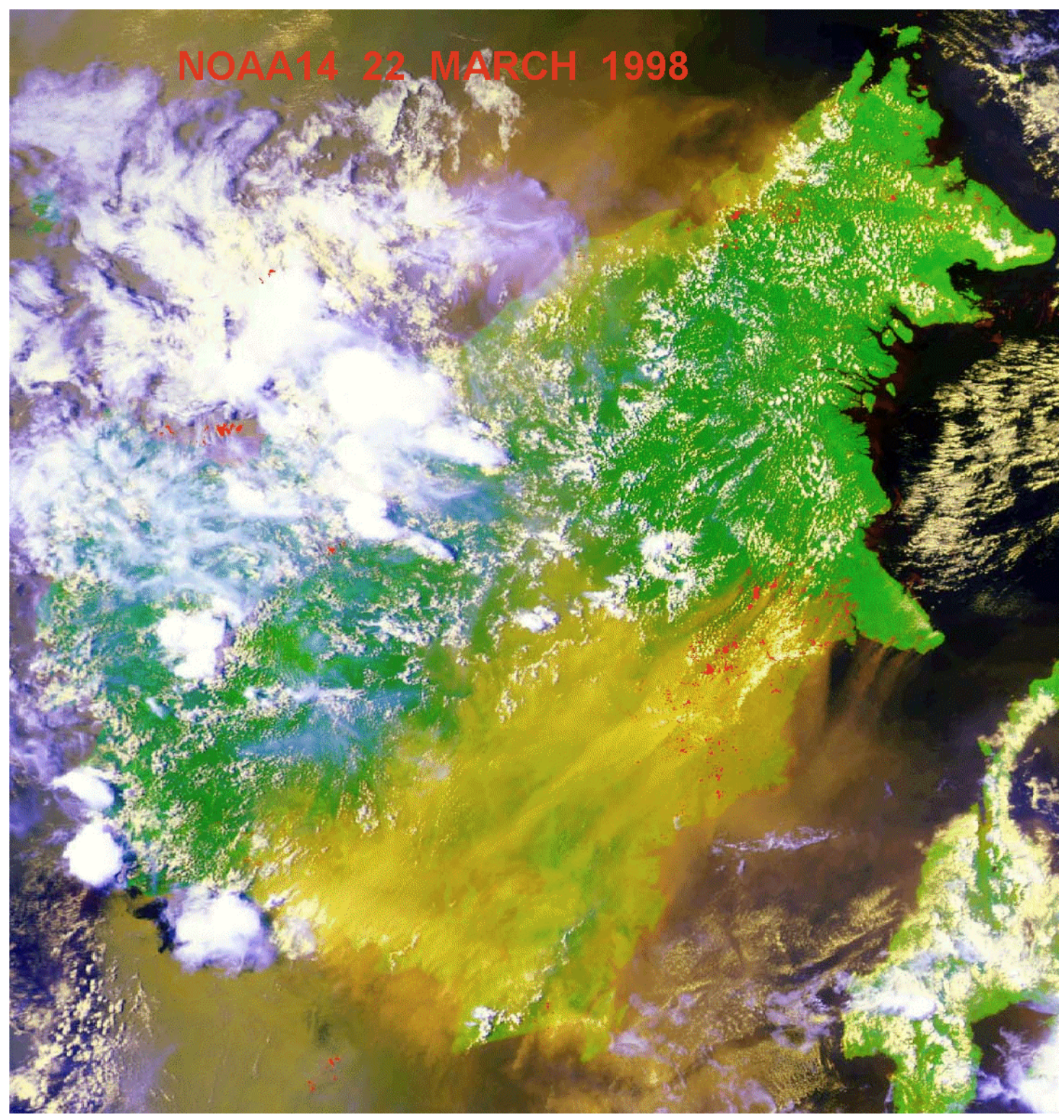


Map 8. Spot Satellite Images of Forest/Plantation Fires and Smoke Haze over Southeast Asia (Fires and smoke haze near Banjarmasin, South Kalimantan)*

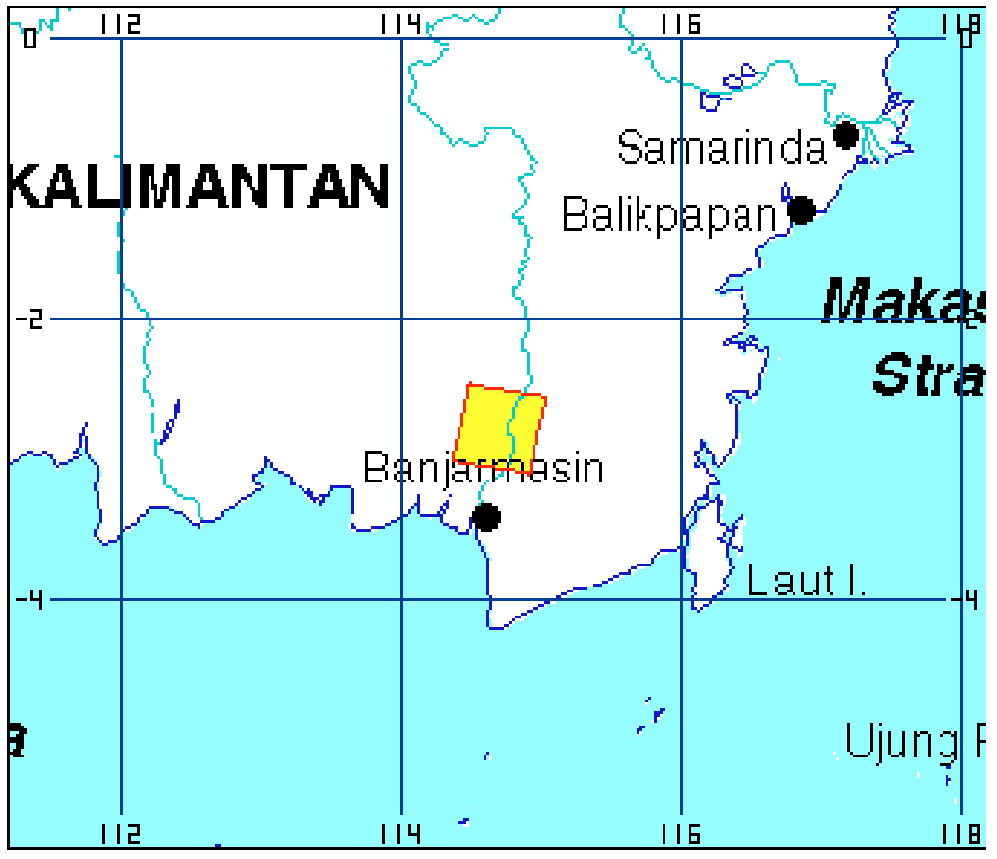

\section{a. 6 June 1997}

Barito River cuts through the image from north to south. West of the river, irrigation channels show up as a grid of pale green lines, enclosing a large plantation. Areas with healthy vegetation show up in red or pink, while bare soil or sparsely vegetated areas show up in various shades of green. The white patches are cumulus clouds, each casting a shadow below it. The image shown covers about $40 \mathrm{~km}$ by $30 \mathrm{~km}$.

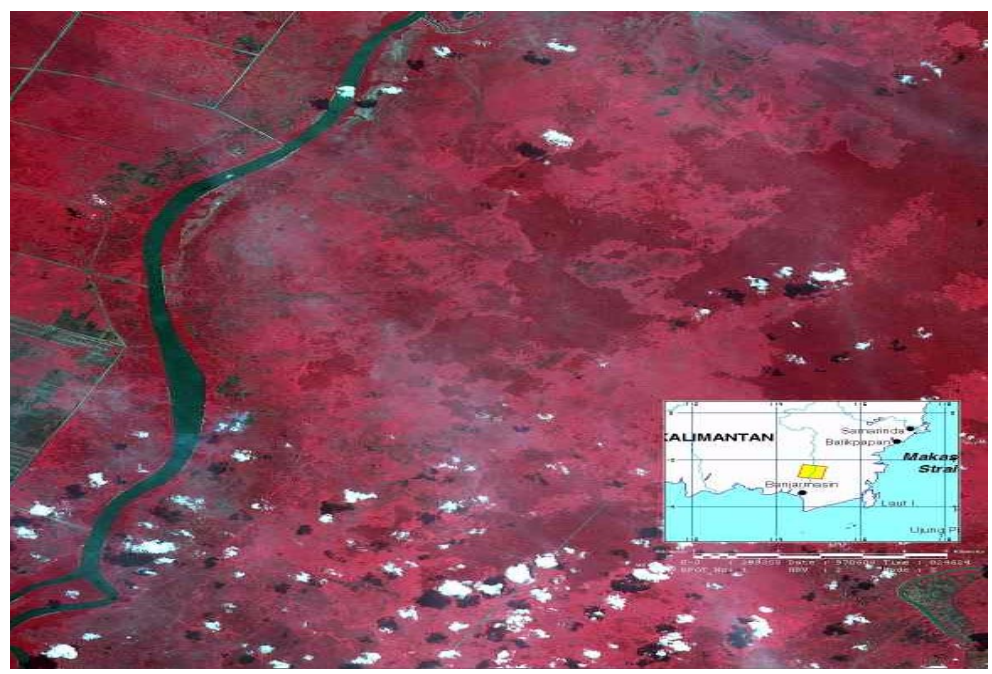

* All images are acquired by the SPOT satellites. Copyright of images belongs to CNES.

Images acquired and processed by the Centre for Remote Imaging, Sensing, and Processing, National University of Singapore. 


\section{b. 14 July 1997}

Many smoke plumes rise from burning vegetation in the plantation area. A few smoke plumes can also be seen to the east of the river, which could be fires started by small farmers. A large extent of the $\mathrm{red} /$ pink area in the previous image have turned dark green, the result of burning in the two month period.

\section{7 August 1997}

Burning intensifies and the area west of the Barito River is now shrouded in smoke haze.
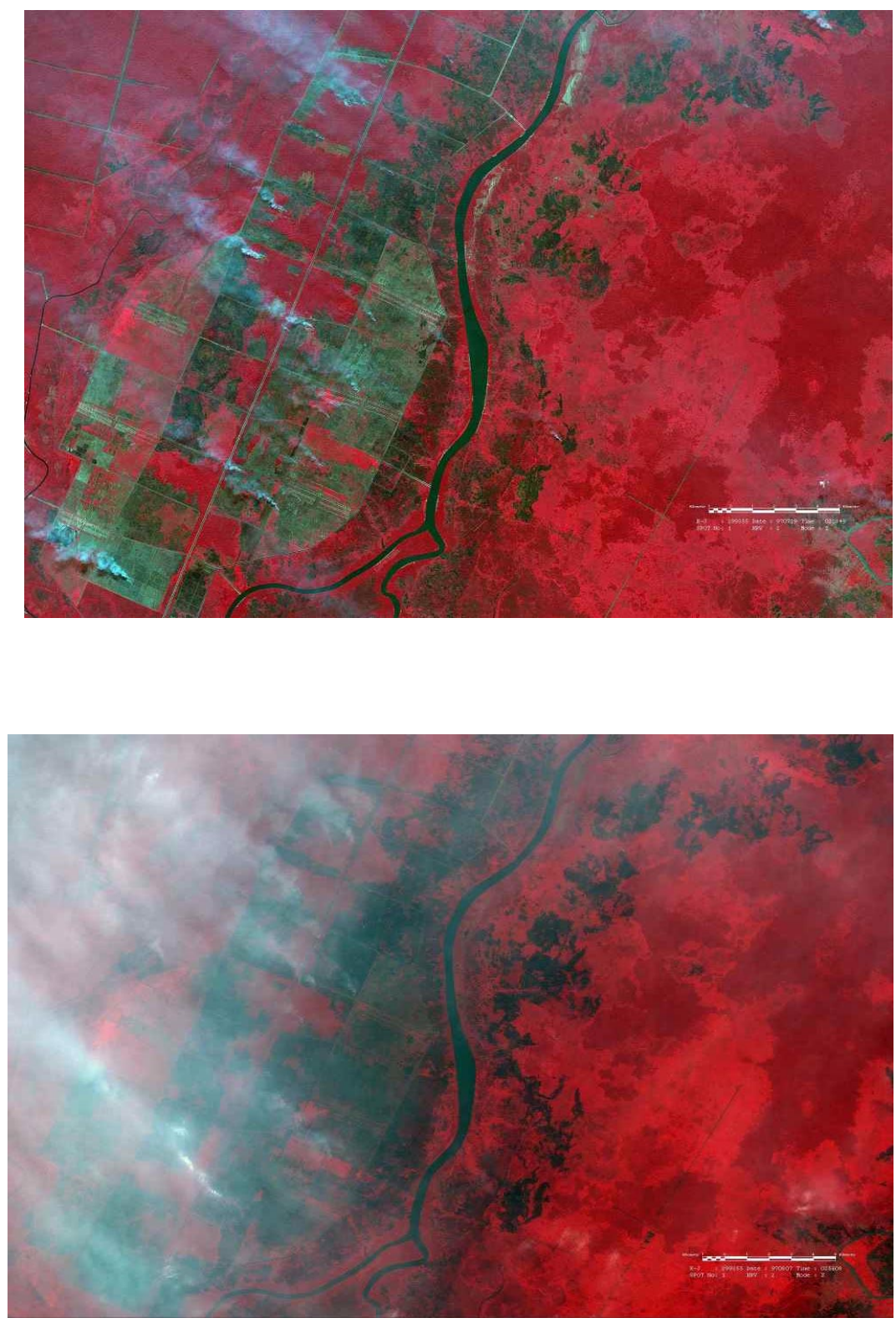


\section{d. 28 August 1997}

The whole area is now obscured by dense smoke haze. Through the thick haze, we can see that nearly all the vegetation in the plantation and near the river is burnt.

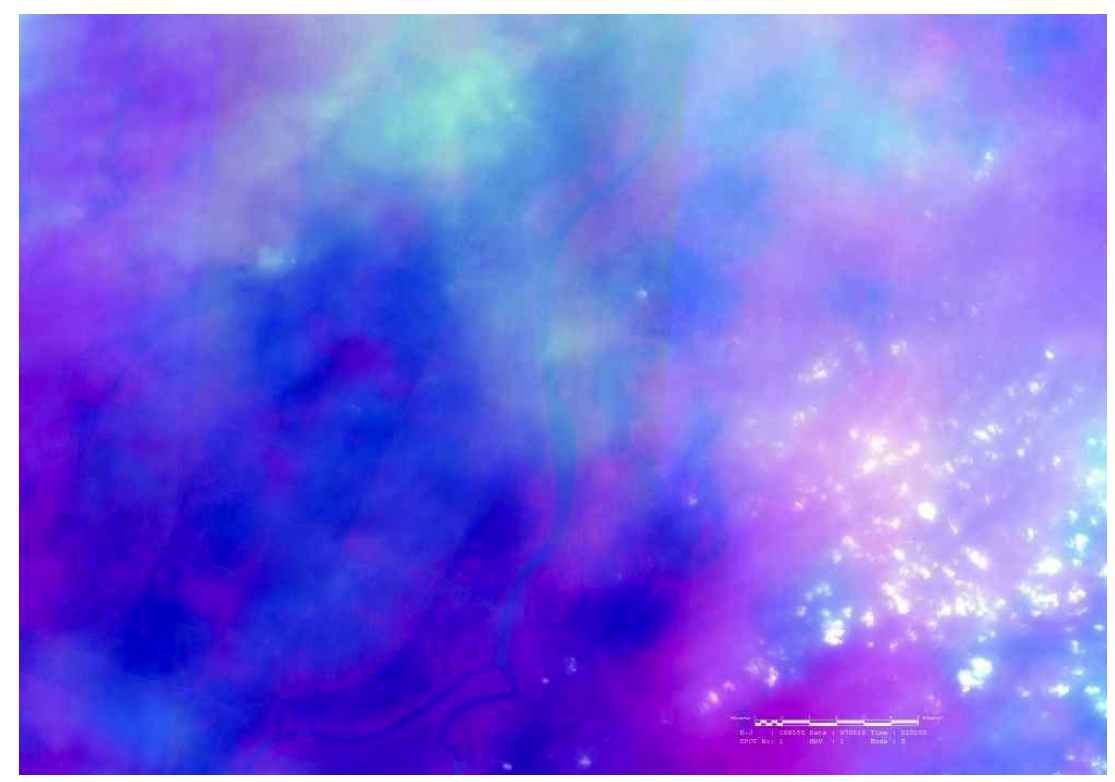

\section{e. September 1997}

The smoke haze has lifted on this day, offering a temporary reprieve and revealing the extent of the damage. Systematic land clearing by fire is however still in progress.

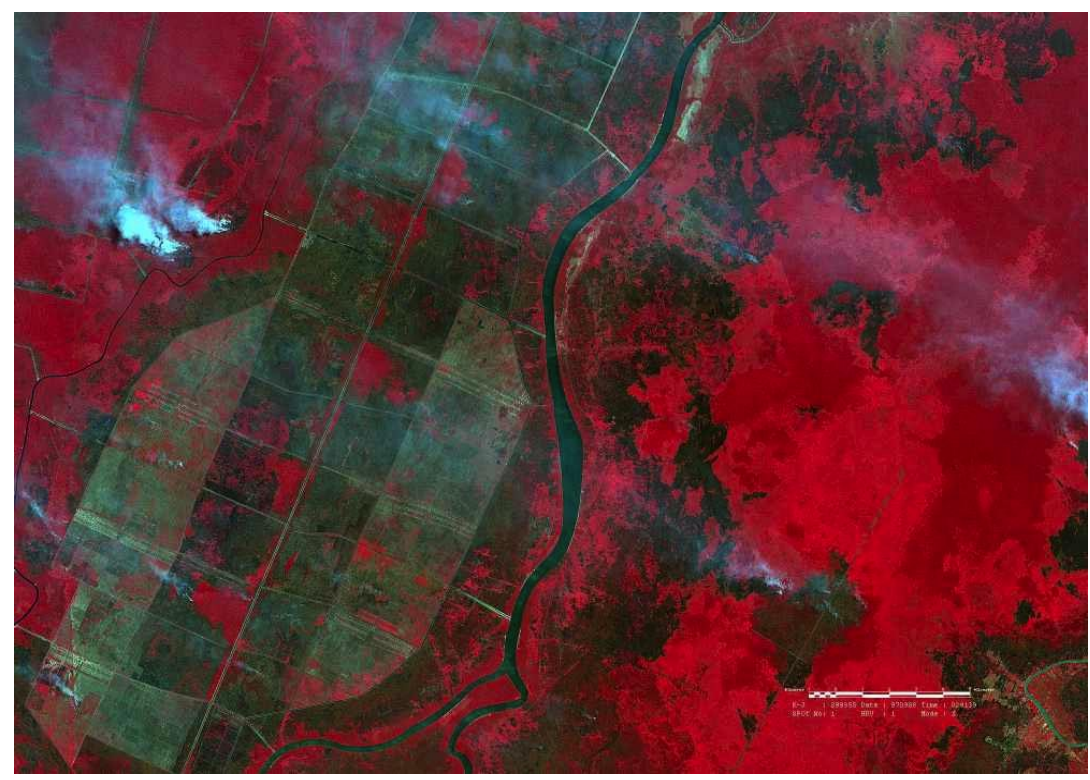


Map 9. Example of processed NOAA AVHRR image of the southern coast of Kalimantan, dated 8 October 1997, from the NOAA web site

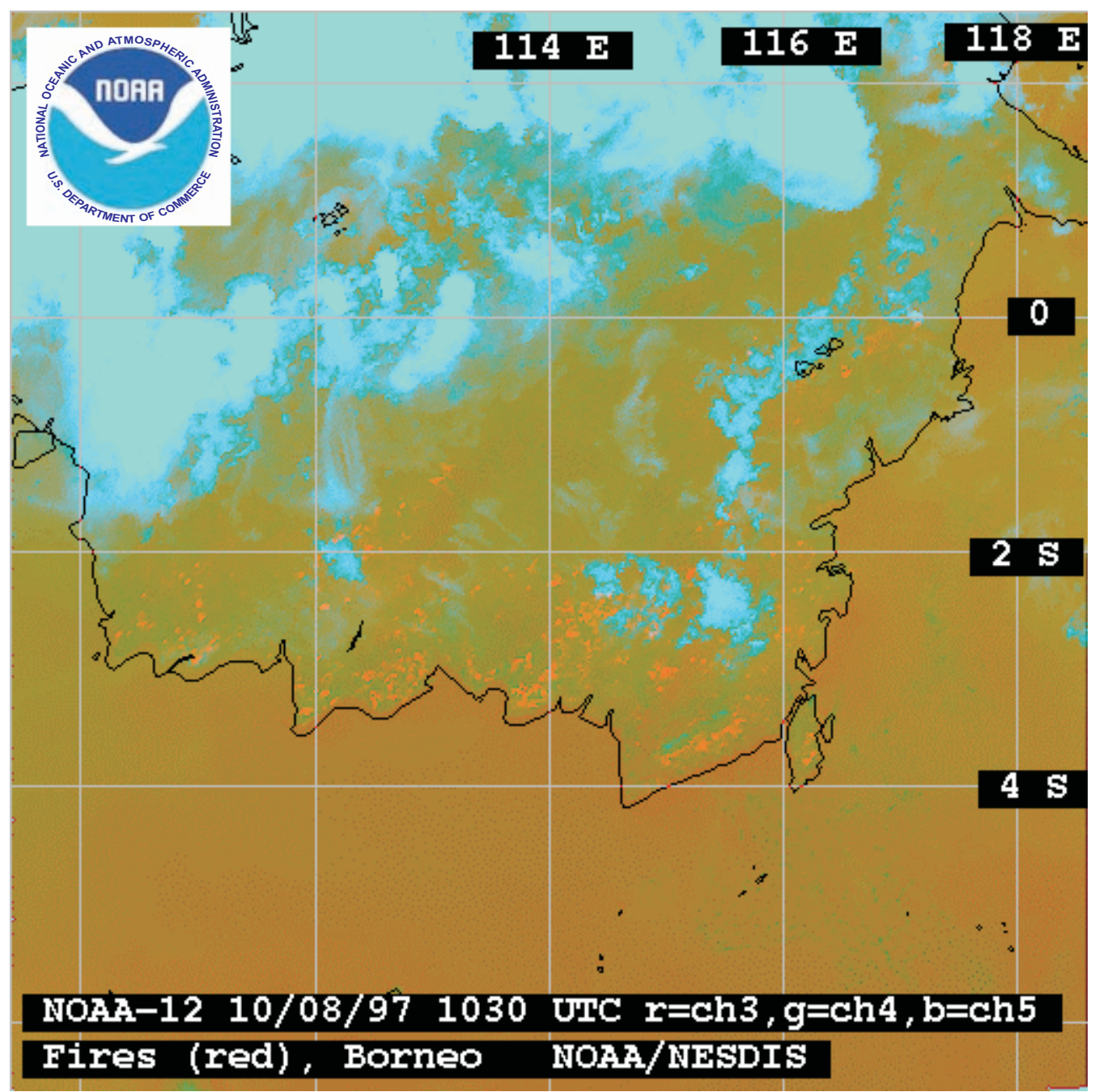


Map 10a. Example of fire map for Central Kalimantan coastal area, October 1997, from the USDA Forest Service web site.

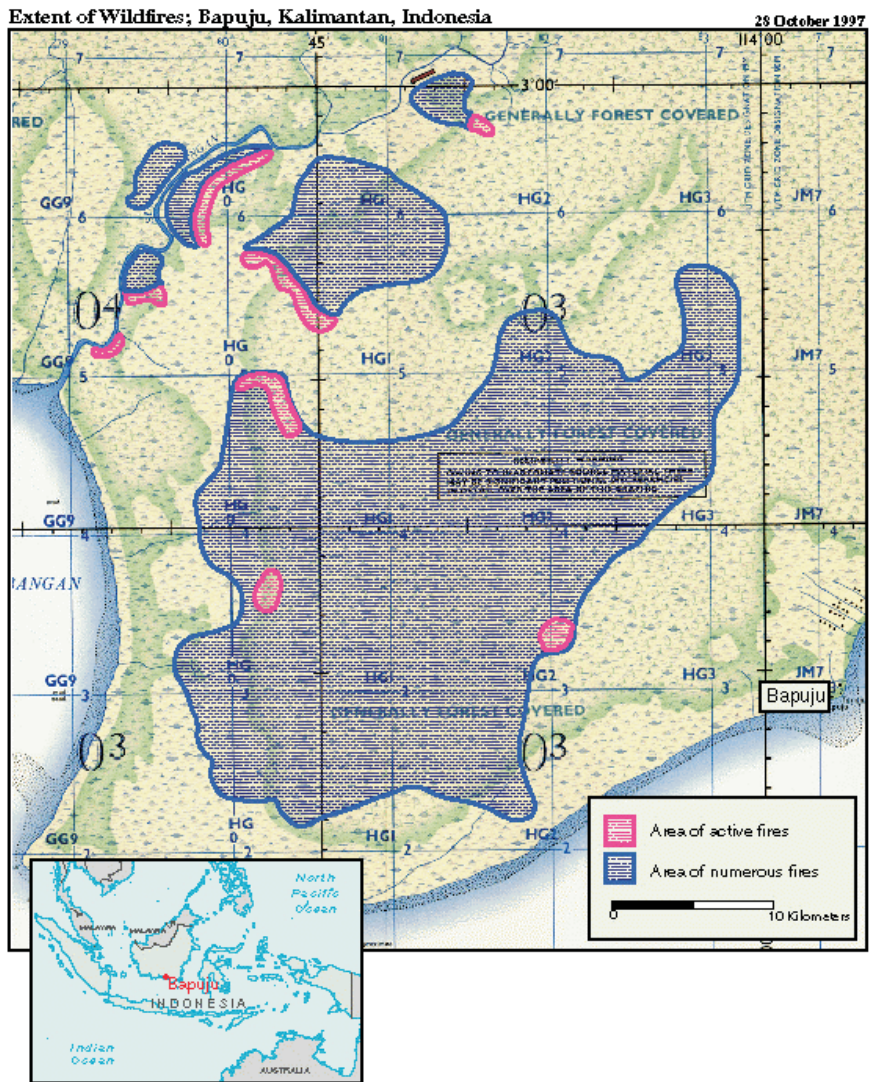

Map 10b. Example of fire map for East Kalimantan, February 1998, from the USDA Forest Service web site.

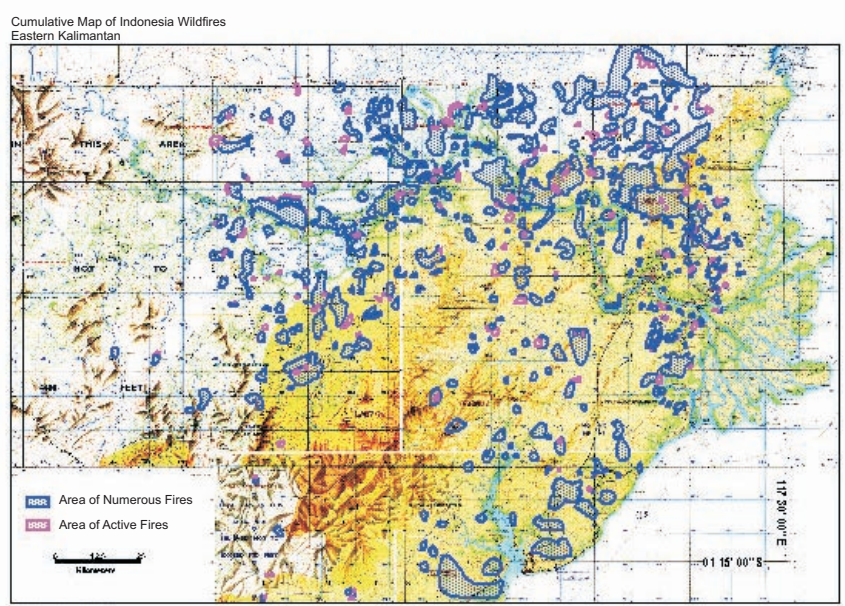


Map 11. Example of TOMS smoke image over Indonesia during the 1997 fire event

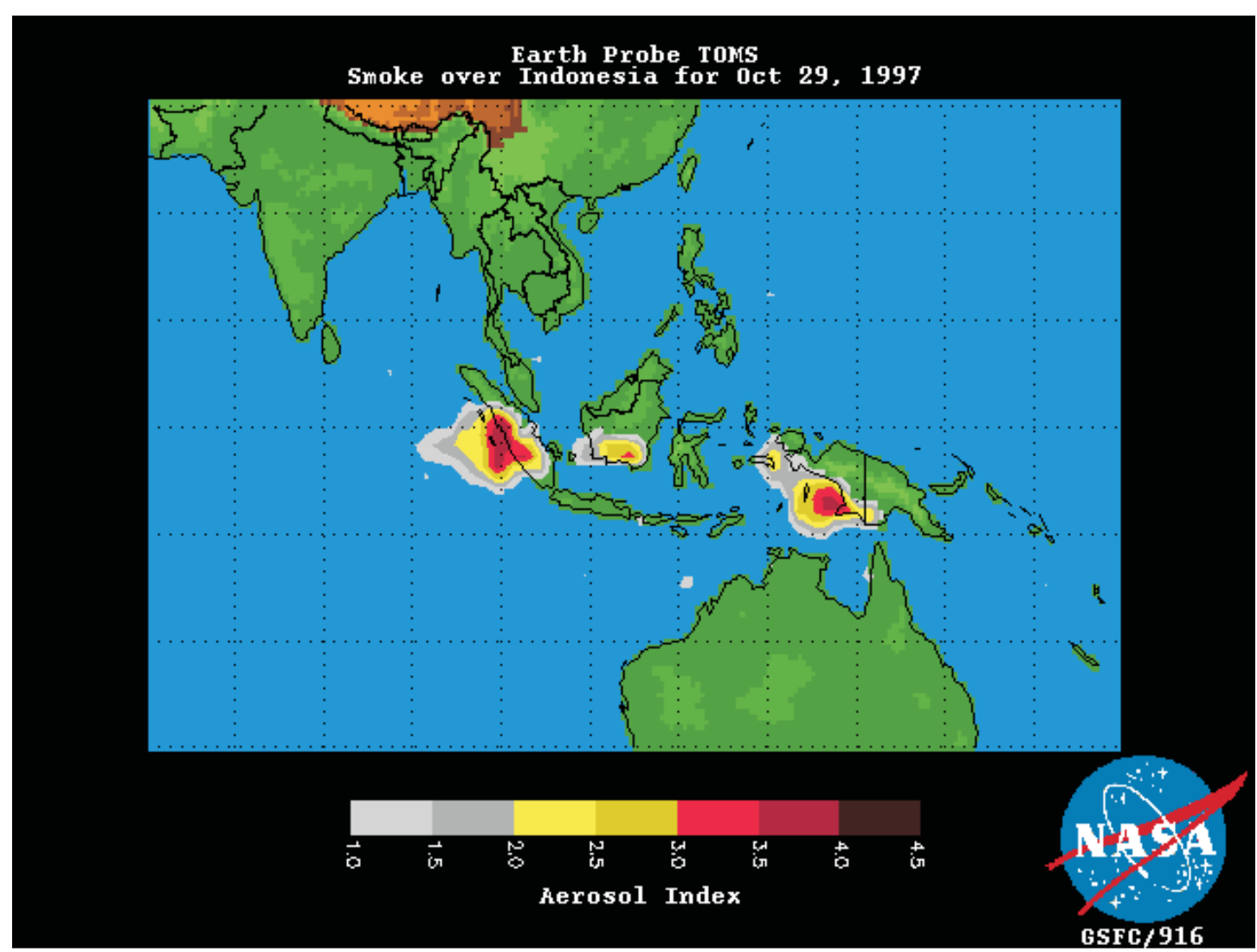


Map 12a. Example of Precipitation Map from AFWIS

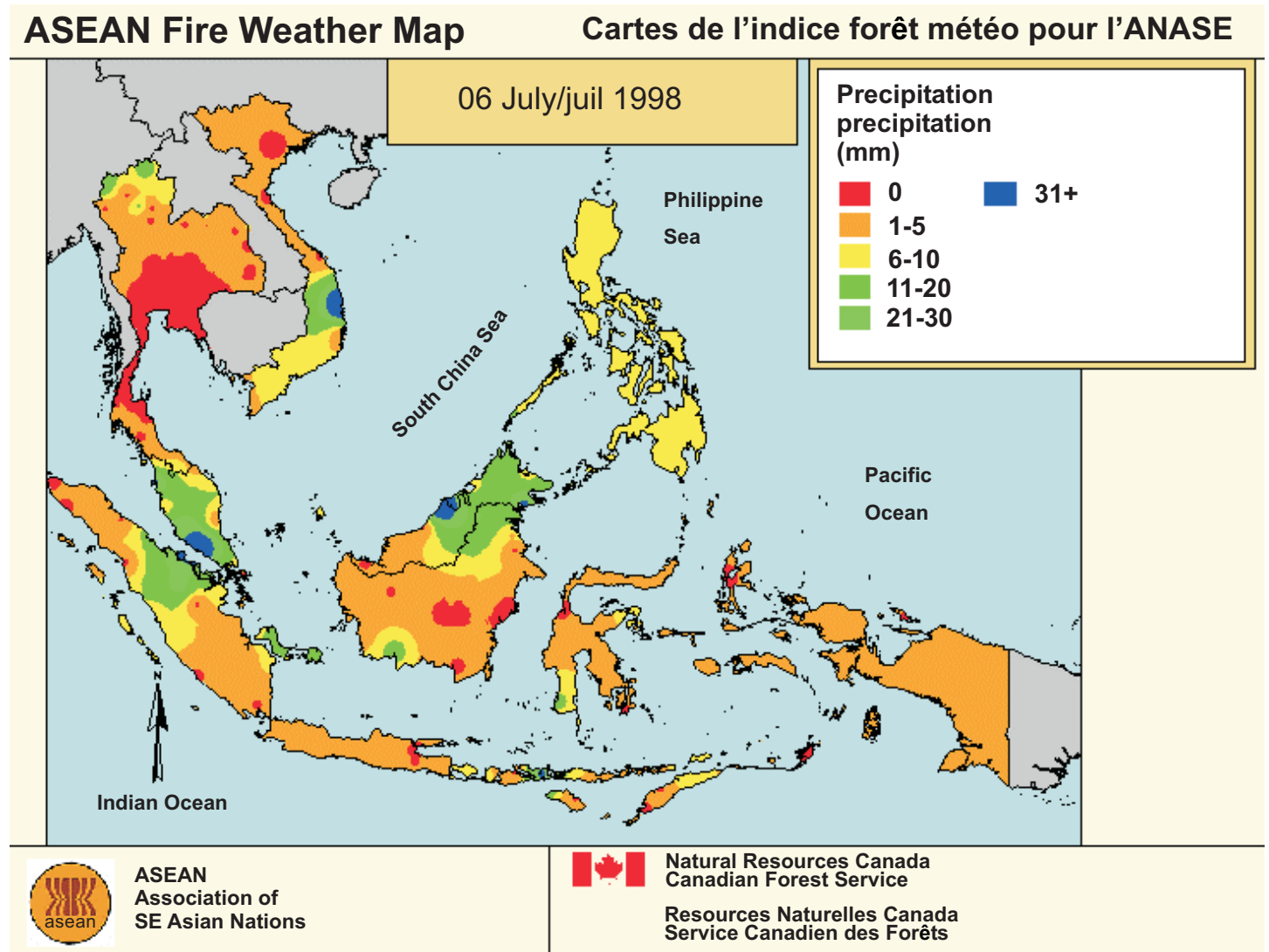


Map 12b. Example of Fire Weather Index Map from AFWIS

ASEAN Fire Weather Map

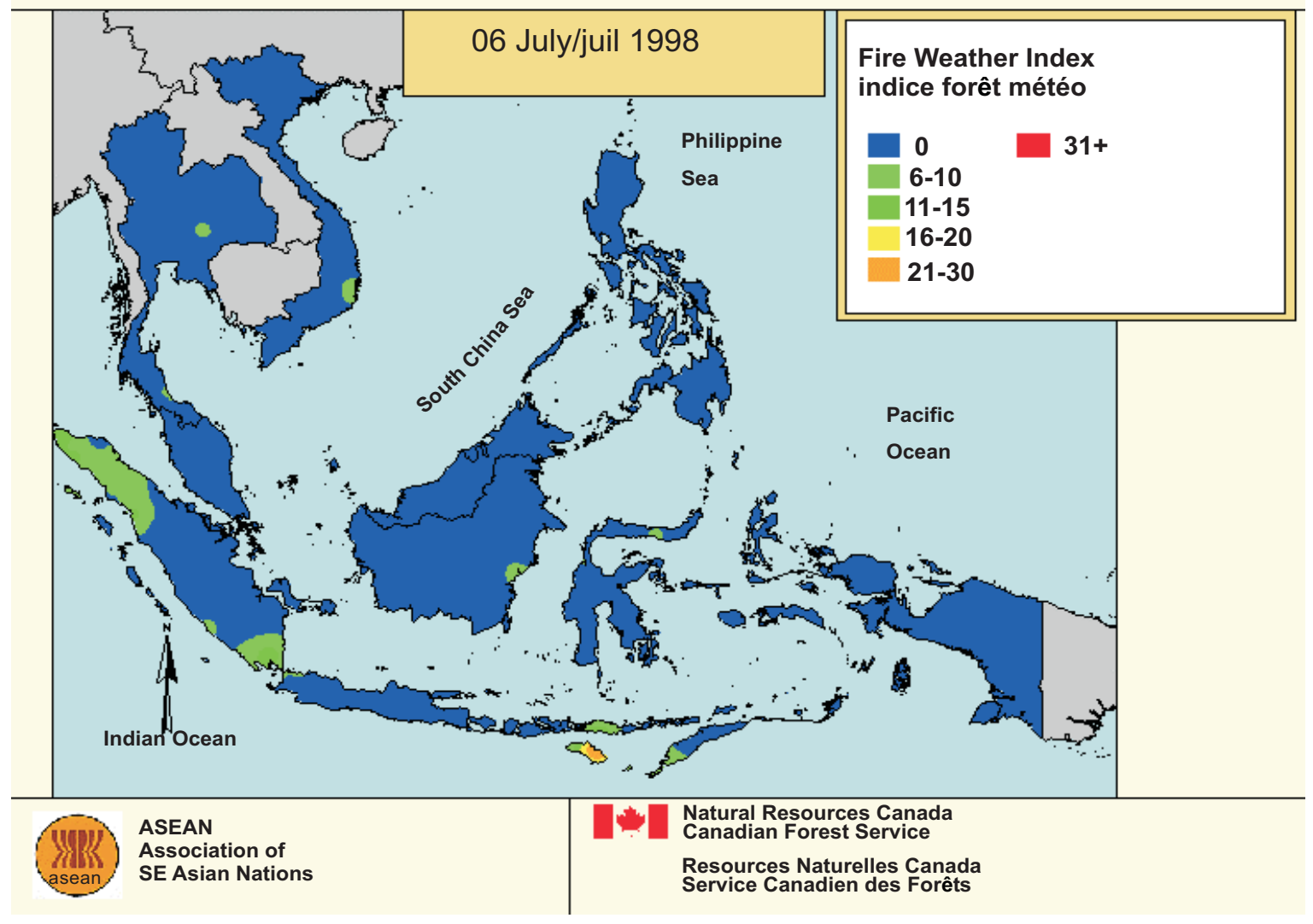

Cartes de l'indice forêt météo pour l'ANASE

Fire Weather Index dice forêt météo 


\section{Appendix 4. Reference List from Meijaard and Dennis (1997) Forest Fire Bibliography}

Anderson, J.A.R. 1965 The limestone habitat in Sarawak. In: Proceedings of the symposium on ecological research in humid tropics and vegetation, 49-57. UNESCO, Kuching, Malaysia.

Anderson, J.A.R. 1976 Observations on the ecology of five peat swamp forests in Sumatra and Kalimantan. Soil Research Institute Bogor Bulletin 3: 45-55.

Anderson, J.A.R. and Chai, P.P.K. 1982 Vegetation. Gunung Mulu National Park, Sarawak. Sarawak Museum Journal (Special Issue No. 2) 30(51): 195-223.

Angelsen, A. 1995 Shifting cultivation and 'deforestation': a study from Indonesia. World Development 23: 1713-29.

Anonymous 1995 Bentuang Karimun Nature Reserve. ITTO Project 26/93 Rev. 1 (F). Development of Bentuang Karimun Nature Reserve as a National Park. Phase 1. Operational Plan. September 1995. WWF, Jakarta, Indonesia. $37 \mathrm{pp}$.

Arino, O. and Melinotte, J. M. 1995 Fire index atlas. Earth Observation Quarterly 50 (December). European Space Agency.

Azuma, S. 1987 Distribution and abundance of primates after the forest fire in the lowland forest of East Kalimantan 1983-86. Primate Research Centre, Kyoto University, Japan.

Azuma, S. and Wirawan, N. 1994. Early recovery process of Kutai ecosystem - a preliminary report. Kyoto University Primate Research Centre. 124 pp.

Balgooy van, M.M.J. 1996 Vegetation sketch of the Aru islands. In: H.P. Nooteboom (ed.) The Aru archipelago: plants, animals, people and conservation, 1-14. Mededelingen No. 30.
Netherlands Commission for International Nature Protection, Amsterdam, the Netherlands.

Beaman, R.S., Beaman, J.H., Marsh, C.W. and Woods, P.V. 1985 Drought and forest fires in Sabah in 1983. Sabah Society Journal 8(1): 1030.

Belward, A.S., Grégoire, J-M., D’Souza, G., Trigg, S., Hawkes, M., Brustet, J-M., Serca, D., Tireford, J-L., Charlot, J-M. and Vuattoux, R. 1993a. Insitu, real-time fire detection using NOAA/ AVHRR data. In: 6th AVHRR Data Users Meeting, Belgirate, Italy, 29 June-2 July 1993, 333-9. EUMETSAT, Darmstadt, Germany.

Belward, A.S., Kennedy, P.J. and Grégoire, J-M. 1993b The limitations and potential of AVHRR GAC data for continental fire studies. International Journal of Remote Sensing 15: 2215-34.

Bishop, K.D. 1984 A preliminary report on the reserves of southeast Irian Jaya: Pulau Kimaan (Dolok), Wasur, Rawa Biru, Kumbe-Merauke and Danau Bian. WWF/IUCN project 1528. International Council for Bird Preservation. Unpublished report, Cambridge, UK.

Blasco, F. 1983 The transition from open forest to savanna in continental Southeast Asia. In: F. Bourlière (ed.) Tropical savannas, ecosystems of the world 13, 167-81. Elsevier Scientific Publishing Company, Amsterdam, the Netherlands.

Blower, J.H. and Zon van der, A.P.M. 1977 Proposed Ujung Kulon National Park, Management Plan 1977-1981. Field report of UNDP/FAO. Nature Conservation and Wildlife Management Project INS273/013. Bogor, Indonesia. $90 \mathrm{pp}$. 
Borssum-Waalkes van, J. 1951 Pulau Panaitan (Prinsen-eiland): Botanisch gedeelte. [in Dutch]. In: Hoogerwerf 1951. (no reference available): 159-81

Bruenig, E.F. 1961 An introduction to the vegetation of Bako National Park. Government Printer, Kuching, Malaysia.

Bruenig, E.F. 1965. A guide and introduction to the vegetation of the kerangas forests and the padangs of the Bako National Park. In: Proc. Symp. Ecol. Res. Humid. Trop. Vegetation. Kuching, Sarawak. July 1963. Government of Sarawak and UNESCO, Tokyo: 289-319.

Bruenig, E.F. 1966. The heath forests of Sarawak and Brunei. Thesis, Hamburg University and published in 1968, Der Heidewald vor Sarawak und Brunei. I. Standort und Vegetation. II. Artenbeschreibung und Anhänge. [in German]. Mitteilungen der Bundesforschungsanstalt ForstHolzwirtschaft no. 68. Vols. I and II.

Bruenig, E.F. 1996 Conservation and management of tropical rainforest. An integrated approach to sustainability. CAB International and Cambridge University Press, Cambridge, UK. 339 pp.

Chandler, C., Cheney, P., Thomas, P., Trabaud, L. and Williams, D. 1983 Fire in forestry. Volume I. John Wiley and Sons, New York. 450 pp.

Chandradewana Boer 1989 Investigations of the steps needed to rehabilitate the areas of East Kalimantan seriously affected by fire: effects of the forest fire 1982-83 in East Kalimantan on wildlife, FR-report No. 7. Feldkirchen: Deutsche Forstservice GmbH, Germany.

Chuvieco, E. and Martin, M.P. 1994 Global fire mapping and fire danger estimation using AVHRR images. Photogrammetric Remote Sensing and Engineering, 605: 563-70.

Collins, N.M., Holloway, J.D. and Proctor, J. 1984. Notes on the ascent and natural history of Gunung Api, a limestone mountain in Sarawak. Sarawak Museum Journal 33: 219-34.
Collins, N.M., Sayer, J.A. and Whitmore, T.C. 1991 The conservation atlas of tropical forests. Asia and the Pacific. WCMC and Macmillan Press Ltd, London and Basingstoke, UK. 256 pp.

Courlett, R.T. 1984 Human impact on subalpine vegetation of Mt. Wilhelm, Papua New Guinea. Journal of Ecology 72: 841-54.

Craven, I and de Fretes, Y. 1987 Arfak Mountains Nature Conservation Area, Irian Jaya: management plan 1988-1992. WWF Project 3770. World Wildlife Fund, Bogor, Indonesia. $175 \mathrm{pp}$.

Crutzen, P.J. and Andreae, M.O. 1990 Biomass burning in the tropics; impact on atmospheric chemistry and biogeochemical cycles. Science 250: 1669-78.

Crutzen, P.J. and Zimmermann, P.H. 1991 The changing photochemistry of the atmosphere. Tellus 43: 176-81.

Daud Leppe 1993 Wilding system of Hopea nervosa (Dipterocarpaceae) and their performance in burned over forest. Wanariset Technical Papers 1993-1. Balikpapan, Indonesia.

Dennis, R.A., Pierce Colfer, C.J. and Puntodewo, A. in press 1997 Forest cover change among fishers and shifting cultivators in West Kalimantan: Implications for local level sustainability. CIFOR Working Paper, Bogor, Indonesia.

Dilmy, A. 1965 The effect of fire used by early man on the vegetation of the human tropics. In: Proceedings Symposium on the impact of man on humid tropics vegetation, Goroka, 1960, 11926. Administration of the Territory of PNG and UNESCO, Tokyo, Japan.

Doi, T. 1988 Present status of the large mammals in the Kutai National Park, after a large scale fire in East-Kalimantan, Indonesia. pp 127.

Dove, M. 1983 Forest preference in swidden agriculture. Tropical Ecology 24: 122-42.

Duff, A.B., Hall, R.A. and Marsh, C.W. in press, 1987 A survey of wildlife in and around a 
commercial tree plantation in Sabah. Malaysian Forester.

Dunn, F.L. 1982 Rainforest collectors and traders, a study of resource utilization in modern and ancient Malaya, 2nd edn. Monograph 5. Malaysian Branch, Royal Asiatic Society, Kuala Lumpur, Malaysia.

Eden, M.J. 1974 The origin and status of savanna and grassland in southern Papua. Transactions of the Institute of British Geographers 63: 47, 97110.

FAO/UNEP 1981 Tropical Forest Resources Assessment Project: Forest resources of tropical Asia. Food and Agriculture Organization, Rome, Italy.

Fehr, C. 1993 Forest fires in Thailand. International Forest Fire News 9(July): 17-21. United Nations Economic Commission for Europe, Food and Agricultural Organisation, Rome, Italy.

Fishman, J., Fakrhuzzaman, K., Cros, B. and Nganga, D. 1991 Identification of widespread pollution in the southern hemisphere deduced from satellite analysis. Science 252: 1693-6.

Fishman, J., Logan, J., Artaxo, P.E., Cachier, H., Carmichael, G.R., Dickinson, R., Fosberg, M.A., Helas, G., Kanakidou, M., Lacaux, J.P. and Rohrer, F. 1993 Group report: What is the impact of fires on atmospheric chemistry, climate and biogeochemical cycles ? In: P.J Crutzen and J.G. Goldammer (eds.) Fire in the environment: the ecological, atmospheric, and climatic importance of vegetation fires. Report of the Dahlem Workshop, Berlin, 15-20 March 1992, 346-56. John Wiley and Sons, Chichester, UK.

Flasse, S.P. and Ceccato, P. 1996 A contextual algorithm for AVHRR fire detection. International Journal of Remote Sensing 17(2): 419-24.

Flasse, S.P., Ceccato, P., Downey, I. D., Williams, J.B., Navarro, P., Raimadoya, M.A. 1996 Remote sensing and GIS tools to support vegetation fire management in developing countries. Paper presented at $13^{\text {th }}$ Conference on
Fire and Forest Meteorology, 27-31 October 1996, Lorne, Australia.

Flenley, J.R. 1988 Palynological evidence for land use changes in Southeast Asia. Journal of Biogeography 15: 185-97.

Gerlach, L.W.C. 1881 Reis door het meergebied van de Kapoeas in Borneo's Westerafdeeling. [in Dutch]. Bijdragen tot de Taal-, Land-en Volkenkunde van Nederlandsch-Indië, 4de reeks, 5: 285-322.

Giesen, W. 1990 Vegetation of the Negara river basin. In: Zieren, T, Permana and Giesen, W. (eds.) Conservation of Sungai Negara wetlands, Barito Basin, South Kalimantan, 1-55. Proceedings of a workshop held in Banjarbaru, Kalimantan Selatan, 6-8 March 1989. PHPA/ AWB-Indonesia, Bogor in cooperation with KPSL-UNLAM, Bogor, Indonesia.

Giesen, W. 1996 Habitat types and their management: Danau Sentarum Wildlife Reserve, West Kalimantan, Indonesia. Wetlands International Indonesia Programme/PHPA, Bogor, Indonesia. 97 pp.

Giesen, W. 1997 A brief survey of Wasur National Park, Irian Jaya, Indonesia. With special emphasis on the flora and vegetation. Indonesian Wetland Data Base IRJ20. Wetlands International Indonesia Programme, Bogor, Indonesia.

Gilkes, L. and Adapati, E. 1987 Teluk Cendrawasih Marine Conservation Area, Irian Jaya: management plan 1988-1992. WWF/IUCN Project No. 3770. WWF-Indonesia, Bogor. 145 pp.

Gillison, A.N. 1969. Plant succession in an irregularly fires grassland area - Doma Peaks Region, Papua. Journal of Ecology 57: 415-28.

Goldammer, J.G. 1988 Rural land-use and wildland fires in the tropics. Agroforestry Systems 6: 235-52.

Goldammer, J.G. 1990 Fire in the tropical biota. Ecosystem processes and global challenges. 
Ecological Studies Vol. 84. Springer-Verlag, Berlin, Germany.

Goldammer, J.G. 1992a Viet Nam: a fire problem analysis. International Forest Fire News 7(August): 13-61. United Nations Economic Commission for Europe, Food and Agricultural Organisation, Rome, Italy.

Goldammer, J.G. 1992b Tropical forests in transition: ecology of natural and anthopogenic disturbances processes - an introduction. In: Goldammer, J.G. (ed.) Tropical forest transition, 1-16. Birkhäuser Verlag, Basel, Switzerland.

Goldammer, J.G. 1993 Historical biogeography of fire: tropical and subtropical. In: Crutzen, P.J. and Goldammer, J.G. (eds.) Fire in the environment: the ecological, atmospheric, and climatic importance of vegetation fires. Report of the Dahlem workshop, Berlin, 15-20 March 1992, 297-314. John Wiley and Sons, Chichester, UK.

Goldammer, J.G. and Siebert, B. 1989 Natural rain forest fires in Eastern Borneo during the Pleistocene and Holocene. Naturwissenschaften 76: 518-20.

Goldammer, J.G. and Siebert, B. 1990 The impact of droughts and forest fires on tropical lowland rain forest of East Kalimantan. In: J.G. Goldammer (ed.) Fire in the tropical biota. Ecosystem processes and global challenges, 1131. Ecological Studies Vol. 84. Springer-Verlag, Berlin, Germany.

Haantjens, H.A., Mabbutt, J.A. and Pullen, R. 1965. Anthropogenic grasslands in the Sepik Plains, New Guinea. Pacific Viewpoint 6: 215-19.

Halenda, C. 1985. Site protection and rehabilitation by shifting cultivators in the Julau, Pakan, and Kapit areas. Report on a field survey. Forest Department Sarawak, R.O. (047) 62(VIII) 1(2) August. 4 pp.

Hartono, B. and Sato, Y. 1993 Donor countries' activities on Indonesia forest fire prevention, control and mitigation. JICA, Jakarta, Indonesia. $37 \mathrm{pp}$.
Heersink, C. 1996 Interaction between man and landscape in South Sulawesi in the early modern period. Indonesian Environmental History Newsletter No. 7 (June): 13-14.

Heyligers, P.C. 1963 Vegetation and soil of whitesand savanna in Surinam. North Holland Publisher, Amsterdam, the Netherlands.

Heyligers, P.C. 1966 Observations on Themeda australis-Eucalyptus savannah in Papua. Pacific Science 20: 477-89.

Hommel, P.W.F.M. 1987 Landscape-ecology of Ujung Kulon (West Java, Indonesia). PhD dissertation, Soil Survey Institute, Wageningen, the Netherlands.

Hoogerwerf, J. 1970 Udjung Kulon, the land of the last Javan rhinoceros. Brill, Leiden, the Netherlands. $512 \mathrm{pp}$.

Johnson, B. 1984 The great fire of Borneo - report of a visit to Kalimantan Timur a year later. WWF, Jakarta, Indonesia.

Joint Research Centre. 1993. Fire in Global Resource and Environmental (FIRE) monitoring. proposal 1994-97. Institute for Remote Sensing Applications-Monitoring of Tropical Vegetation. European Commission, Ispra, Italy.

Jones, S.H. 1997 Vegetation fire in mainland Southeast Asia: spatio-temporal analysis of AVHRR $1 \mathrm{~km}$ data for the 1992/93 dry season. Space Applications Institute, JRC, Ispra, Italy. 48 pp.

Jordan, C.F. 1989 An Amazonian rainforest. The structure and function of a nutrient-stressed ecosystem and the impact of slash-and-burn agriculture. UNESCO, Paris, France, and Parthenon, Carnforth, UK.

Kaars, van der, S. and Dam, M.A.C. 1995 A 135,000-year record of vegetational and climatic change from the Bandung area, West Java, Indonesia. Palaeogeography, Paleoclimatology, Palaeoecology 117: 55-72.

Kartawinata, K. 1980 The environmental consequences of tree removal from the forest in Indonesia. In: Where have all the flowers gone? 
Deforestation in the Third World. Studies in Third World Societies Publications No. 13. Boswell, Wiliamsburg, Virginia.

Kartawanita, K. 1984 Environmental effects of different kinds of land use. LIPI-Indonesian MAB Committee Doc. No. 39. Jakarta, Indonesia.

Kartawinata, K. and Widjaja, E. 1988 Consultant's report of preparation for development for Lorentz National Park, Irian Jaya. UNESCO/Government of Indonesia UNDP/IBRD Project INS/83/013, Jakarta. 73 pp.

Kartawinata, K., Adisoesmarto, S., Riswan, S. and Vayda, A.P. 1981 The impact of man on a tropical forest in Indonesia. Ambio 10: 115-19.

Kartawinata, K., Soedjito, H., Jessup, T., Vayda, A. and Colfer, C. 1984 The impact of development on interactions between people and forests in East Kalimantan: a comparison of two areas of Kenyah Dayak settelement. East-West Environment and Policy Institute reprint No. 76, Honolulu. East-West Environment and Policy Institute. Originally published in The Environmentalist 4, supplement no. 7: 87-95.

Kauffman, J.B. and Uhl, C. 1990 Interactions of anthropogenic activities, fire, and rain forests in the Amazon basin. In: Goldammer, J.G. (ed.) Fire in the tropical biota. Ecosystem processes and global challenges, 117-34. Ecological Studies Vol. 84. Springer-Verlag, Berlin, Germany.

Kaufmann, Y., Setzer, A., Justice, C., Tucker, C.J., Pereira, M.C. and Fung, I. 1990a Remote sensing of biomass burning in the tropics. In: Goldammer, J.G. (ed.) Fire in the tropical biota. Ecosystem processes and global challenges, 371-99. Ecological Studies Vol. 84. Springer-Verlag, Berlin, Germany.

Kaufmann, Y., Tucker, C.J. and Fung, I. 1990b Remote sensing of biomass burning in the tropics. Journal of Geophysical Research 95: 9927-39.

Keller, M., Jacob, D.J., Wofsy, S.C. and Harris, R.C. 1991 Effects of tropical deforestation on global and regional atmospheric chemistry. Climatic Change 19: 145-58.
Kennedy, P.J. 1992. Biomass burning studies: the use of remote sensing. Ecological Bulletins 42: 133-48.

Kennedy, P.J., Belward, A.S. and Grégoire, J-M. 1994 An improved approach to fire monitoring in West Africa using AVHRR data. International Journal of Remote Sensing 15: 2235-55.

Kershaw, A.P. 1994 Pleistocene vegetation of the humid tropics of northeastern Queensland, Australia. Palaeogeography, Palaeoclimatology, Palaeoecology 109: 399-412.

Kershaw, A.P. and Bohte, A. 1997 The impact of prehistoric fires on tropical peatland forests. In: Rieley, J.O. and Page, S.E. (eds.) Tropical peatlands, 73-80. Samara Publishing Ltd., Cardigan, UK.

Kershaw, A.P. and Kaars, van der, S. 1995 Fossil records of biomass burning and vegetation change: proxies for human occupation and environmental impact. Abstracts, Australian Society of Human Biology Annual Conference, Melbourne, 1995.

Kershaw, A.P., Bush, M.B., Hope, G.S., Weiss, KF, Goldammer, J.G. and Sanford, R. Jr. 1996 The contribution of humans to past biomass burning in the tropics. In: Clark, J. (ed.) Sediment records of biomass and global change. Springer Verlag, New York.

Komarek, E.V. 1967 Fire and ecology of man. Tall Timbers Fire Ecology Conference Proceedings 2: 181-87.

Komarek, E.V. 1969 Fire and animal behaviour. Tall Timbers Fire Ecology Conference Proceedings 8: 169-97.

Kostermans, A.J.G.H. 1958 Secondary growth on areas of former peat swamp forest. Proceedings of the Symposium on the Humid Tropics, Ciawi, Indonesia: 155-69.

Kusumowidagdo, M. 1993 Manfaat data satelit penginderaan jauh untuk deteksi kebakaran hutan. [in Indonesian]. Jurnal GIS 4: 82-91. EMDI/KLH Publication, Jakarta, Indonesia. 
Langaas, S. 1992 Temporal and spatial distribution of savanna fires in Senegal and The Gambia, West Africa, 1989-90, derived from multi-temporal AVHRR night images. International Journal of Wildland Fire 2: 21-36.

Leighton, M. and Wirawan, N. 1986 Catastrophic drought and fire in Borneo tropical rainforest associated with the 1982-83 El-Niño Southern Oscillation event. In: Prance, G. (ed.) Tropical rain forests and the world atmosphere, 75-102. AAAS Symposium 101, Westbury Press, Boulder, Colorado.

Lennertz, R. and Panzer, K.F. 1983 Preliminary assessment of the drought and forest fire damage in Kalimantan Timur. Transmigration Areas Development Project (TAD), German Agency for International Cooperation (GTZ), Jakarta, Indonesia. Typescript.

Logan, J.A. 1985 Tropospheric ozone: seasonal behavior, trends, and anthropogenic influence. Journal of Geophysical Research 90: 10.463-82.

Luttrell, C. 1994 Forest burning in Danau Sentarum. Preliminary report for AWB/PHPA, June 1994. Bogor, Indonesia. 21 pp.

Mackie, C. 1984 The lessons behind East Kalimantan's forest fires. Borneo Research Bulletin 16: 63-74.

Mackie, C., Jessup, T.C., Vayda, A.P. and Kartawinata, K. 1987 Shifting cultivation and patch dynamics in an upland forest in East Kalimantan, Indonesia. In: Hadi, Y., Awang, K., Majid, N.M. and Mohamed, S. (eds.) Proceedings of regional workshop on impact of man's activities on tropical upland forest ecosystems, 465-518. Faculty of Forestry, Universiti Pertanian Malaysia, Kuala Lumpur.

MacKinnon, J. (ed.) 1983 Tanjung Puting National Park. Management plan for development. World Wildlife Fund Project 1523, Field Report. Bogor, Indonesia. $65 \mathrm{pp}$.

MacKinnon, K. 1988 Consultant's report of biodiversity specialist for USAID paid mission.
Natural resources management in Kalimantan. EMDI, Jakarta, Indonesia. 45 pp.

MacKinnon, K., Hatta, G., Halim, H. and Mangalik, A. 1996 The ecology of Kalimantan. Periplus Edition (HK) Ltd, Hong Kong. 872 pp.

Malingreau, J. P. 1990 The contribution of remote sensing to the global monitoring of fires in tropical and subtropical ecosystems. In: Goldammer, J.G. (ed.) Fire in the tropical biota. Ecosystem processes and global challenges, 337-70. Ecological Studies Vol. 84. Springer-Verlag, Berlin, Germany.

Malingreau, J.P., Stephens, G., and Fellows, L. 1985 Remote sensing and forest fires: Kalimantan and North Borneo in 1982-83. Ambio 14: 314-21.

Malingreau, J.P., Tucker, C.J. and Laporte, N. 1989 AVHRR for monitoring global deforestation. International Journal of Remote Sensing 10(45): 855-67.

Maloney, B.K. 1985 Man's impact on the rainforests of West Malaysia: the palynological record. Journal of Biogeography 12: 537-58.

Manner, H. and Lang, H. 1981 A quantitative analysis of the induced grasslands of the Bismarck Mountains, Papua New Guinea. Journal of Tropical Geography 2(1): 40-8.

Mayer, J. 1996 Impact of the East Kalimantan forest fires of 1982-83 on village life, forest use, and land use. In: Padoch, C. and Peluso, N.L. (eds.) Borneo in transition. People, forests, conservation, and development, 187-218. SouthEast Asian Social Sciences Monographs. Oxford University Press, Kuala Lumpur.

McCarthy, A. (ed.) 1991 Conservation areas of Indonesia. Final draft. World Conservation Monitoring Centre, UK.

Michielsen, W.J.M. 1882 Verslag eener reis door de boven districten der Sampit en Katingan rivieren in maart en april 1880. [in Dutch] Tijdschrift voor Indische Taal, Land- en Volkenkunde XXVIII: 1-87. 
Mitchell, A., de Fretes, Y. and Poffenberger, M. 1990 Community participation for conservation area management in the Cyclops mountains, Irian Jaya, Indonesia. In: Poffenberger, M. (ed.) Keepers of the forest: land management alternatives in Southeast Asia. Kumarian Press, West Hartford, Connecticut.

MOF 1991 Indonesia Forestry Action Plan. Country brief. Vol. 2 of 3. Ministry of Forestry of Republic of Indonesia, Jakarta, Indonesia. 172 pp.

Molengraaff, G.A.F. 1900 Geologische verkenningstochten in Centraal Borneo (189394). Borneo expeditie. [in Dutch] Maatschappij ter bevordering van het Natuurkundig Onderzoek der Nederlandsche Koloniën. E.J. Brill, Leiden/ Gerlings, Amsterdam, the Netherlands.

Myers, N. 1980 Conversion of tropical moist forests. National Research Council Washington, DC.

Myers, N. 1984 The primary source: tropical forests and the earth's future. W.W. Norton, New York.

Myers, N. 1987 Trends in the destruction of rain forests. In: Marsh, C.W. and Mittermeier, R.A. (eds.) Primate conservation in the tropical rain forest. Monographs in Primatology, Vol. 9. Alan R. Liss, Inc., New York.

Myers, N. 1988 Tropical deforestation and climatic change. Environmental Conservation 15: 293-7.

Nazif, M. 1988 Percobaan pengendalian Acacia arabica herbisida Indamin $720 \mathrm{HC}$, Garlon $480 \mathrm{EC}$ dan trusi di Taman Nasional Baluran, Jawa Timur. Bulletin Penelitian Hutan 499: 11-24.

Nieuwenhuis, A.W. 1907 Quer duch BorneoErgebnisse seiner Reisen in den Jahren 1894, 1896-1897, und 1898-1900. [in German] Vol. 1. Buchhandlung und Druckerei vormals E.J. Brill, Leiden, the Netherlands. 493 pp.

Ovington, J.D. 1984 Ecological processes and national park management. In: McNeely, A. and Miller, K.R. (eds.) National parks, conservation, and development, 60-4. Smithsonian Institution Press, Washington, DC.

Paaijmans, K. (ed.) 1976 New Guinea vegetation. Elsevier Scientific Publishing Company, Amsterdam, the Netherlands.

Penner, J.E., Dickenson, R.E. and O'Neill, C.A. 1992 Effects from aerosol from biomass burning on the global radiation budget. Science 32: 10105 .

Pereira, M.C. and Setzer, A.W. 1993 Spectral characteristics of deforestation fires in NOAA/ AVHRR images. International Journal of Remote Sensing 14: 583-97.

Persoon, G. and Iongh de, H. 1996 Local people between shark fishers and nature conservationists: the social context of the Aru Tenggara Marine Reserve. In: Nooteboom, H.P. (ed.) The Aru archipelago: plants, animals, people and conservation, 35-56. Mededelingen No. 30. Netherlands Commission for International Nature Protection, Amsterdam, the Netherlands.

Petocz, R., Wirawan, N. and MacKinnon, K. 1990 The Kutai National Park: planning for action. WWF, Bogor, Indonesia.

Pfeiffer, I. 1856 Meine zweite Reise um die Welt [in German]. 1st edition 1856, 2 volumes: 11415. Vienna, Austria.

PHPA 1994 Tanjung Puting National Park Management Plan 1994-2019. Volume II. Ministry of Forestry, Directorate General of Forest Protection and Nature Conservation (PHPA), Jakarta, Indonesia. 135 pp.

Pickford, S., Suharti, M. and Wibowo, A. 1992 A note on fuelbeds and fire behaviour in alangalang (Imperata cylindrica). International Journal of Wildland Fire 2: 41-6.

Poffenberger, M. and McGean, B. (eds.) 1993 Communities and forest management in East Kalimantan: pathways to environmental stability. Southeast Asia Sustainable Forest Management network, Research Network Report, No. 3, August 1993. Center for Southeast Asian Studies, University of Berkeley, California. 
Polak, B. 1949 Verslag ener tournee naar de Kapuas en Kapuasmeren van 18 september - 30 oktober 1949. [In Dutch]. Verslag van het Bodemkundig Instituut van het Algemeen Proefstation voor de Landbouw, Bogor, Indonesia. Typescript. $32 \mathrm{pp}$.

Prevedel, D.A. 1995 Project Sparkey: a strategic wildfire monitoring package using AVHRR satellites and GIS. Photogrammetric Engineering and Remote Sensing, 61(3): 271-8.

Primack, R.B. and Lovejoy, T.E. 1995 Ecology, conservation, and management of Southeast Asian rainforest. Yale University Press, New Haven. 304 pp.

Pyne, S.J. 1995 World fire. The culture of fire on earth. Henry Holt and Company, New York. 379 pp.

Rabinowitz, A.R. 1990 Fire, dry Dipterocarp forest, and the carnivore community in Huai Kha Khaeng wildlife sanctuary, Thailand. Journal of Tropical Ecology 7: 37-47.

Rambo, A.T. 1980 Fire and the energy efficiency of swidden agriculture. Asian Perspectives 23: 309-16.

Ratcliffe, J.B. 1984 Cagar Alam Pegunungan Cyclops, Indonesia. Management Plan 1985-89. WWF-Indonesia, Jayapura, Indoneisa. 95 pp.

Reynders, J.J. 1961 Some remarks: shifting cultivation in Netherlands New Guinea. Netherlands Journal of Agricultural Science 9(1): 36-40.

De Franca, A., Ricardo, J., Brustet, J.-M. and Fontan, J. 1995 A multispectral remote sensing of biomass burning in West Africa. Submitted to Journal of Atmospheric Chemistry 22: 81-110.

Riswan, S. and Kartawinata, K. 1991 Species strategy in early stage of secondary succession associated with soil properties status in a lowland mixed Dipterocarp forest and kerangas forest in East Kalimantan. Tropics 1: 13-34.

Riswan, S. and Yusuf, R. 1986 Effects of forest fires on trees in the lowland Dipterocarp forest of East Kalimantan, Indonesia. In: Proceedings of the symposium on forest regeneration in Southeast Asia, Bogor, Indonesia, 9-11 May 1984, 155-63. BIOTROP Special Publication No. 25. Regional Centre for Tropical Biology, Bogor, Indonesia.

Sandberg, D.V. et al. 1979 Effects of fire on air: a state-of knowledge review. U.S. Forest Service General Technical Report WO-9. USFS, Washington, DC. $40 \mathrm{pp}$.

Sarwono 1989 Investigations of the steps needed to rehabilitate the areas of East Kalimantan seriously affected by fire: Effects of the forest fire 1982-83 in East Kalimantan on fisheries and hydrology, FR-report No. 8. Feldkirchen: Deutsche Forstservice $\mathrm{GmbH}$, Jakarta, Indonesia.

Schindele, W., Thoma, W. and Panzer, K. 1989. Investigations of the steps needed to rehabilitate the areas of East Kalimantan seriously affected by fire: The forest fire 1982-83 in East Kalimantan, part I: The fire, the effects, the damage, the technical solutions, FR-report No. 5, Feldkirchen: Deutsche Forstservice $\mathrm{GmbH}$, Jakarta, Indonesia.

Schneider, H. 1995 Development of a fire detection and vegetation monitoring system based on local reception of NOAA satellite data. Indonesia-UK Tropical Forest Management Programme, Jakarta, Indonesia. 22 pp.

Schwaner, C.A.L.M. 1853 Borneo. Beschrijving van het stroomgebied van den Barito en reizen langs eenige voorname rivieren van het zuidoostelijke gedeelte van dat eiland, op last van het gouvernement van Nederl. Indië gedaan in de jaren 1843-47. [In Dutch]. Vol I. P.N. van Kampen, Amsterdam, the Netherlands. 234 pp.

Seavoy, R.E. 1975 The origin of tropical grasslands in Kalimantan Indonesia. Journal of Tropical Geography 40: 48-51.

Seiler, W. and Crutzen, P.J. 1980 Estimates of gross and net fluxes of carbon between the biosphere and atmosphere from biomass burning. Climatic Change 2: 207-47. 
Shimokawa, E. 1988 Effects of fire of tropical rainforest on soil erosion. In: Tagawa, $\mathrm{H}$. and Wirawan, N. (eds.) A research on the process of earlier recovery of tropical rain forest after a large scale fire in Kalimantan Timur, Indonesia, 2-11. Occasional Paper No. 14. Research Centre for the South Pacific. Kagoshima University, Japan.

Silvius, M.J, Simons, H. and Verheugt, W.J.M. 1984 Soils, vegetation, fauna and nature conservation of the Berbak Game Reserve, Sumatra. RIN contributions to research on management of natural resources 1983-84. Research Institute for Nature Management. Arnhem, the Netherlands. 130 pp.

Smits, W.T.M. 1994 Dipterocarpaceae: Micorrhizae and regeneration. Tropenbos Series, Wageningen, the Netherlands.

Spears, J.S. 1983 Saving the tropical forest ecosystem. Discussion Paper. World Bank Washington, DC.

Steenis van, C.G.G.J. 1957 Outline of the vegetation types in Indonesia and some adjacent regions. Eight Pacific Science Congress, Vol. IV (Botany): 61-97.

Steenis van, C.G.G.J. (assisted by Mrs. A.F. Schippers-Lammertse) 1965 Concise plantgeography of Java. In: Backer, C.A. and Bakhuysen van den Brink, R.C. (eds.) Flora of Java: Vol. I, Noordhoff, Groningen, the Netherlands $72 \mathrm{pp}$.

Stott, P. 1986 The spatial pattern of dry season fires in the savanna forest of Thailand. Journal of Biogeography 13: 345-58.

Stuttard, M., Boardman, S., Gooding, R., Downey, I., Flasse, S., Ceccato, P. and Muirhead, K. 1995 Global vegetation fire product: final report. EOS95/125-Fr-001. Joint Research Centre, Space Applications Institute, Ispra, Italy.

Suzuki, A. 1984 The distribution of primates and the survey on the affection of forest fires, 1983, in and around Kutai Nature Reserve of East Kalimantan, Indonesia.
Suzuki, A. 1992 The population of orang-utans and other non-human primates and the forest conditions after the 1982-83 fires and droughts in Kutai National Park, East Kalimantan, Indonesia. In: Ismail, G., Mohamed, M. and Omar, S. (eds.) Forest biology and conservation in Borneo, 129-205. Center for Borneo Studies Publication No. 2.

Tagawa, H. and Wirawan, N. (eds.) 1988 A research on the process of earlier recovery of tropical rain forest after a large scale fire in Kalimantan Timur, Indonesia. Occasional Paper No. 14. Research Centre for the South Pacific. Kagoshima University, Japan.

Tempo, 1987. Setelah hutan jadi arang [When the forest turned to charcoal]. No. 32(10): 49-71 [in Indonesian].

Torquebiau, E.F. 1985 Dynamic behaviour in vegetation. In: Remote sensing in vegetation studies. Report of the ESCAP-BIOTROP training course on remote sensing techniques applied to vegetation studies, 182-90. Bogor, Indonesia.

United Nations 1970 Integrated river basin development. UN, New York.

Vaas, K.F. 1952 Fisheries in the Lake District along the Kapuas River in West Borneo. Proceedings of Indo-Pacific Fisheries Council, Section II: 1-10. Diocesan Press, Madras, India.

Vayda, A.P. and Sahur, A. 1985 Forest clearing and pepper farming by Bugis migrants in East Kalimantan: Antecedents and impact. East-West Environment and Policy Institute Reprint no. 83. EWC, Hawaii (Originally published In: Indonesia 39: 93-110).

Watanabe, H., Ruaysongern, S. and Takeda, H. 1983 Soil animals. In: Shifting cultivation, 11026. Ministry of Sciences, Technology, and Energy, Bangkok, Thailand.

Wells, M.P. 1989 Can Indonesia's biological diversity be protected by linking economic development with national park management? 
Three case studies from the Outer Islands. World Bank Report, Washington, DC. 59 pp.

Westermann, J. H. 1938 Natuur in Zuid- en Oost Borneo. [in Dutch]. In: 3 jaren Indisch Natuurleven, 11e jaarverslag (1936-38). Nedederlandsch-Indische Vereeniging tot Natuurbescherming (Batavia): 334-97.

Wharton, C. 1968 Man, fire and wild cattle in Southeast Asia. Proceedings of the Tall Timber Fire Ecology Conference 8: 107-67.

Whitmore, T.C. 1984 Tropical rainforests of the Far East (2nd edition) Clarendon Press, Oxford, UK.

Whitmore, T.C. 1990 An introduction to tropical rainforests. Clarendon Press, Oxford, UK.

Whitten, T., Soeriaatmadja, R.E. and Afiff, S.A. 1996 The ecology of Java and Bali. Periplus Edition (HK) Ltd, Hong Kong. 969 p. + illustrations.

Wilde de, W.J.J.O. 1993 On the species character of the flora of the Leuser Park nd vicinity, with emphasis on the high mountain blang vegetation of northern Sumatra. Proceedings of Second Flora Malesiana. Symposium 1992. Yogyakarta/Bogor, Indonesia.

Wilde de, W.J.J.O. and Duyfjes, B.E.E. 1996 Vegetation, floristics, and plant biogeography in Gunung Leuser National Park. In: van Schaik, C.P. and Supriatna, J. (eds.) Leuser. A Sumatran sanctuary, 49-103. Yayasan Bina Hayato Indonesia, Depok, Indonesia.

Williams, J.B. and Rosenberg, L.J. 1993 Operational reception, processing and application of satellite data in developing countries: theory and practice. Annual Conference of the Remote Sensing Society, Chester College 1993, UK, 7683.
Wirawan, N. 1984 Good forests within the burned forest area in East Kalimantan. WWF report 1687. WWF, Bogor, Indonesia.

Wood, A.W. 1979 The effects of shifting cultivation on soil properties: an example from the Karimui and Bomai Plateaux, Simbu Province, Papau New Guinea. Agricultural Journal 30(1-3): 1-9.

Woods, P. 1987 Drought and fire in tropical forests in Sabah. An analysis of rainfall pattern and some ecological effects. In: Kostermans, A.J.G.H. (ed.) Proceedings of the Third Round Table Conference on Dipterocarps. Samarinda, East Kalimantan, 16-20 April 1985, 367-87. UNESCO, Regional Office for Science and Technology for Southeast Asia, Jakarta, Indonesia.

Wulf de, R., Supomo, D. and Rauf, K. 1981 Kerinci-Seblat proposed National Park preliminary management plan 1982-87. Directorate General for Forest Protection and Nature Conservation, Bogor, Indonesia 56 pp.

WWF 1984. Project report No. 1528. Progress report, May-November. WWF-Indonesia, Jayapura, Indonesia. Unpublished. 4 pp.

WWF 1989 Project 3769: Progress report, OctDec. WWF-Indonesia, Bogor, Indonesia. Unpublished. 3 pp.

Yajima, T. 1988 Change in the terrestrial invertebrate community structure in relation to large fires at the Kutai National Park, East Kalimantan (Borneo), Indonesia. In: Tagawa, $\mathrm{H}$. and Wirawan, N. (eds.) A research on the process of earlier recovery of tropical rain forest after a large scale fire in Kalimantan Timur, Indonesia, 63-81. Occasional Paper No. 14. Research Centre for the South Pacific. Kagoshima University, Japan. 


\section{References Cited}

ACIAR (Australian Centre for International Agricultural Research) 1998 Project Proposal 'Fire management systems for sustainable agriculture and forestry development in eastern Indonesia - review workshop'. Project Number FST/96/77. Canberra, Australia.

ADB (Asian Development Bank) 1997 Aide Memoire - Advisory technical assistance planning for prevention and mitigation of drought and fire damage. Jakarta, Indonesia.

ADB 1999 Causes, Extent and Costs of the 1997/ 1998 Fires in Indonesia - Summary of Phase I. Planning for fire prevention and drought management project, July 1998 - March 1999, Asian Development Bank TA 2999-INO, BAPPENAS (BMAEST). Jakarta, Indonesia.

Antikidis, E., Arino, O., Laur, H. and Arnaud, A. 1998 Deforestation evaluation by synergetic use of ERS SAR coherence and ATSR hot spots: The Indonesian fire event of 1997. Earth Observation Quarterly 9: 34-8.

ASEAN (Association of South East Asian Nations) 1995 ASEAN cooperation plan on transboundary pollution. ASEAN Secretariat, Jakarta, Indonesia. $18 \mathrm{pp}$.

ASEAN 1997 Regional Haze Action Plan. Jakarta, Indonesia.

Bird, F.R. 1995 Coal-seam fire suppression and forest fire training in East Kalimantan, Indonesia. IFFM(GTZ-Indonesia) report, Samarinda, Indonesia. $43 \mathrm{pp}$.

Bock, C. 1881 The headhunters of Borneo: A narrative of travel up the Mahakam and down the Barito, also journeyings in Sumatra. Sampson Low, Marston, Searle and Rivington, London, UK. Reprinted Oxford University Press, Singapore, 1985.

Brookfield, H.C., Potter, L. and Byron, Y. 1995 In place of the forest: environmental and socioeconomic transformation in Borneo and
Eastern Malay Peninsula. United Nations University Press, Tokyo, Japan.

Buongiorno, A., Arino, C., Zehner, P. and Goryl, P. 1997 ERS-2 monitors exceptional fires event in South-East Asia. Earth Observation Quarterly 56-57: 1-6.

Byron, N. and Shepherd, G. 1998 Indonesia's fire problems require long term solutions. Natural Resources Perspectives No. 28. ODI, London, UK.

Deddy, K., Rahmadani, F., Samsu, Kasyanto, N. and Suryani 1998 Laporan survey kebakaran hutan di Kalimantan Timur. WWF Indonesia Report, Jakarta, Indonesia. 13 pp.

Dennis, R.A in preparation Forest fires in and around the Danau Sentarum Wildlife Reserve, West Kalimantan. Indonesia-UK Tropical Forest Management Programme, Jakarta, Indonesia.

Dennis, R.A., Colfer, C.J.P and Puntodewo, A. 1998 Fishermen, farmers, forest change and fire. GIS-ASIA Pacific, Feb-March: 26-30.

EEPSEA and WWF (Economy and Environment Programme for South East Asia and World Wide Fund for Nature) 1998a Interim results of a study on the economic value of haze damages in SE Asia. WWF Indonesia and EEPSEA, Jakarta, Indonesia.

EEPSEA and WWF 1998b The Indonesian fires and haze of 1997: the economic toll - interim report. WWF Indonesia and EEPSEA, Jakarta, Indonesia.

EU-FLB (European Union-Forest Liaison Bureau) 1997 Land and tropical forest fires in Indonesia. Background and summary report. Jakarta, Indonesia. 5 pp.

EUFREG (European Union Fire Response Group) 1998. Assessment of the 1997 fires in Indonesia. European Union, Ministry of Forestry and Estate Crops. Jakarta, Indonesia. 
FFPCP (Forest Fire Protection and Control Programme) 1998 Project's final workshop for Phase 1. 24-25 February 1998 in Palembang. Input papers from project experts. Ministry of Forestry and European Union, European Commission. NRI, BCEOM Indonesia, CIRAD Forêt, and SCOT Conseil. Jakarta, Indonesia.

Flasse, S.P. and Ceccato, P. 1996 A contextual algorithm for AVHRR fire detection. International Journal of Remote Sensing 17: 41924.

Fuller, D. and Fulk, M. 1998 An assessment of fire distribution and impacts during 1997 in Kalimantan, Indonesia using Satellite Remote Sensing and Geographic Information Systems. Final Report for WWF-ID, Jakarta, Indonesia.

Gerlach, L.W.C. 1881 Reis door het meergebied van de Kapoeas in Borneo's Westerafdeeling. [in Dutch]. Bijdragen tot de Taal-, Land-en Volkenkunde van Nederlandsch-Indië, 4de reeks, 5: 285-322.

Giesen, W. 1996 Habitat types and their management: Danau Sentarum Wildlife Reserve, West Kalimantan, Indonesia. Wetlands International Indonesia Programme/PHPA, Bogor, Indonesia. $97 \mathrm{pp}$.

Giesen, W. 1987. Danau Sentarum Wildlife Reserve. Inventory, ecology, and management guidelines. World Wildlife Fund Report for DG PHPA, Bogor, Indonesia.

Goldammer, J.G. 1997 Forest fire and smoke management and policy issues in Indonesia and neighbouring countries of South East Asia. Input Paper to the international workshop on National Guidelines on Protection of Forests against Fire, Bogor, 8-9 December 1997. Sponsored by Max Planck Institute for Chemistry, Fire Ecology, and Biomass Burning Research Group, Germany, UN FAO/ECE Team of Specialists on Forest Fires, $\mathrm{UN}$, and GTZ IFFM, Indonesia.

Goldammer, J.G. and Siebert, B. 1990 The impact of droughts and forest fires on tropical lowland rain forest of East Kalimantan. In: Goldammer,
J.G. (ed.) Fire in the tropical biota, 11-31. Springer-Verlag, Berlin, Germany.

Gönner, C. 1997 Forest fires in Kecamatan Jempang, Kutai - some observations from the Field. Short report of the GTZ-MoF Sustainable Forest Management Project East Kalimantan. Samarinda, Indonesia. 3 pp.

Gönner, C. 1998 Conflicts and fire causes in a sub-district of Kutai, East-Kalimantan, Indonesia. (http://smd.mega.net.id/iffm/Fire_Causes.html.) Goodman, J.B., Smith, C.B. and Brady, M. 1997. Indonesia land and forest fires 1997, a Canadian assessment. CIDA Project No. 472/18270 October 1997. Document No. TA/150/97/01. CIDA/BAPEDAL, Jakarta, Indonesia.

Hartono, B. and Sato, Y. 1993 Donor countries activities on Indonesia forest fire prevention, control and mitigation. Jakarta, Indonesia. Unpublished report. $37 \mathrm{p}$.

Henderson, F.M. and Lewis, A.J. (eds.) 1998. Principles and applications of imaging radar. Volume 2 of the Manual of Remote Sensing. Third edition. Editor-in-Chief R.A. Ryerson. Published in cooperation with the American Society for Photogrammetry and Remote Sensing by John Wiley and Sons, Inc., New York. 866p. IFFM/GTZ (Integrated Forest Fire Management Project of GTZ) 1998. Interim report about the fire situation in Kalimantan Timur and the ongoing activities. Updated 7 July 1998. Project document on IFFM/GTZ Web site.

INTAG (Direktorat Jenderal Inventarisasi dan Tata Guna Hutan) 1991 Laporan pemantauan gejala kebakaran hutan di pulau Kalimantan dan Sumatra dengan memanfaatkan data satelit NOAA. INTAG, Departemen Kehutanan, Jakarta, Indonesia.

ITTO (International Tropical Timber Organization) 1997 National guidelines on the protection of forest against fire. Book 1. Draft 3 PD12/93 REV.3 (F). ITTO, CFC, MoF, IPB, Bogor, Indonesia 
IUCN/WWF (International Union for Conservation of Nature and Natural Resources/World Wide Fund for Nature) 1998 A proposal to establish a Collaborative Global Network for Forest Fire Prevention and Control. Version of the proposal submitted to the European Commission, the UN Turner Foundation, and other Donors. Preliminary Discussion Draft, 15 June 1998. IUCN, Gland, Switzerland.

Kartawinata, K., Soedjito, H., Jessup, T., Vayda, A.P. and Colfer, C. 1984 The impact of development on interactions between people and forests in East Kalimantan. In: J. Hanks (ed.) Traditional lifestyles, conservation and rural development, 87-95. Commission on Ecology Papers No. 7. IUCN, Gland, Switzerland.

KLH (Kantor Menteri Negara Lingkungan Hidup) 1998 Analisis kebijakan penanggulangan kebakaran hutan dan lahan tahun 1997. Laporan akhir Posko kebijakan lingkungan hidup. Jakarta, Indonesia.

Legg, C.A 1997 A preliminary report on fires in Sumatra, Kalimantan, Sulawesi, and Irian Jaya during September 1997. Jakarta, Indonesia. Unpublished report.

Lennertz, R. and Panzer, K.F. 1983 Preliminary assessment of the drought and forest fire damage in Kalimantan Timur. Report of the fact-finding mission, Transmigration Area Development Project PN 76.2010.7. DFS German Forestry Service Ltd. for GTZ, Jakarta, Idonesia. Typescript.

Lilley, R. 1998 Reptile and amphibian survey in Central Kalimantan, with special reference to the impact of forest fires. Unpublished report for WWF-IP, Jakarta, Indonesia.

Liew, S.C., Lim, O.K., Kwoh, L.K. and Lim, H. 1998 A study of the 1997 forest fires in South East Asia using SPOT quicklook mosaics. Paper presented at the 1998 IEEE International Geoscience and Remote Sensing Symposium, 610 July 1998, Seattle, WA.
Luttrell, C. 1994. Forest burning in Danau Sentarum. Preliminary report for AWB/PHPA, June 1994. Bogor, Indonesia. 21 pp.

Makarim, N., Arba'I, Y.A. and Brady, M. 1997 Assessment of 1997 land and forest fires in Indonesia: national coordination. Unpublished paper, BAPEDAL, Jakarta.

Meijaard, E., and Dennis, R.A. 1997 Forest fires in Indonesia: bibliography and background information. Unpublished report, WWF, Netherlands.

Melnyk, M. 1997a Fighting fires in Indonesia by the United States Government. Input paper to the National Workshop on Repelita VII of Forestry and the $8^{\text {th }}$ Meeting of the Consultative Group on Indonesian Forestry (CGIF), Cisarua, Bogor, 10-12 December 1997.

Melnyk, M. 1997b USAID's support for the Assessment of Land and Forest Fire Situation: Interpretation of Satellite Imageries. Input paper to the National Workshop on Repelita VII of Forestry and the $8^{\text {th }}$ Meeting of the Consultative Group on Indonesian Forestry (CGIF), Cisarua, Bogor, 10-12 December 1997.

Michielsen, W.J.M. 1882 Verslag eener reis door de boven districten der Sampit en Katingan rivieren in maart en april 1880. [in Dutch]. Tijdschrift voor Indische Taal, Land- en Volkenkunde XXVIII: 1-87.

MoF 1998 Luas kebakaran hutan di Indonesia. (http://mofrinet.cbn.net.id/informasi/phpa/ bakar_5.html)

Molengraaff, G.A.F. 1900 Geologische verkenningstochten in Centraal Borneo (189394). Borneo expeditie. [in Dutch]. Maatschappij ter bevordering van het Natuurkundig Onderzoek der Nederlandsche Koloniën. E.J. Brill, Leiden/ Gerlings, Amsterdam, the Netherlands.

Otsuka, M. 1997 Guidelines for participatory natural resource management for forest fire prevention: a case from Berbak National Park, 
Jambi, Indonesia. Paper presented at the International Workshop on National Guidelines on the Protection of Forests against Fire. Sponsored by IFFM/ITTO at IPB, Bogor, 8-9 December 1997.

Pangestu, M. and Ahmad, M. 1997 Memorandum ASEAN Economic Forum. ASEAN Regional Cooperation on Haze. Jakarta, Indonesia.

Pfeiffer, I. 1856 Meine zweite Reise um die Welt [in German]., 1st edition 1856, 2 volumes: 11415. Vienna, Austria.

Polak, B. 1949 Verslag ener tournee naar de Kapuas en Kapuasmeren van 18 september-30 oktober 1949. [in Dutch]. Verslag van het Bodemkundig Instituut van het Algemeen Proefstation voor de Landbouw, Bogor, Indonesia. Typescript. $32 \mathrm{pp}$.

Potter, L. 1997 Where there's smoke there's FIRE. Search 26: 307-11.

Potter, L. and Lee, J. 1998. Oil Palm in Indonesia: Its Role in Forest Conversion and the Fires of 1997/1998. A report for WWF-Indonesia Programme. Jakarta, Indonesia.

Purnomohadi, N. 1997 Antispasi kebakaran lahan dan hutan. Input paper to the National Workshop on Repelita VII of Forestry and the $8^{\text {th }}$ Meeting of the Consultative Group on Indonesian Forestry (CGIF), Cisarua, Bogor, 10-12 December 1997.

Ramon, J. and Wall, D. 1998 Fire and smoke occurrence in relation to vegetation and land use in South Sumatra Province, Indonesia with particular reference to 1997. Report No. 47 of the European Commission's Forest Fire Prevention and Control Project. Jakarta, Indonesia.

Saleh, C. 1998 Wildlife survey report from burned and unburned forest areas in Central Kalimantan. WWF-IP, Jakarta, Indonesia.

Schindele, W., Thoma, W. and Panzer, K. 1989 Investigation of the steps needed to rehabilitate the areas of East Kalimantan seriously affected by fire. The forest fire 1982-83 in East Kalimantan. Part I: The fire, the effects, the damage, and the technical solutions. GTZ-PN:
38.3021.3-11.000, ITTO: PD 17/87(F). GTZ and ITTO, Jakarta, Indonesia. Typescript.

Schindler, L. 1998 The Indonesian fires and the SE Asian haze 1997-98. Review, damages, causes, and necessary steps. Paper presented at the Asia-Pacific Regional Workshop on Transboundary Atmospheric Pollution. 27-28 May 1998, Pan Pacific Hotel, Singapore.

Schneider, H. 1995 Development of a fire detection and vegetation monitoring system based on local reception of NOAA satellite data. Indonesia-UK Tropical Forest Management Programme Report, Jakarta, Indonesia. 22 pp.

Schweithelm, J. 1998 The fire this time - an overview of Indonesia's forest fires in 1997-98. Discussion Paper for Project ID162 Analysis of the Causes and Impacts of Forest Fires and Haze. WWF-Indonesia, Jakarta, Indonesia.

Siegert, F. and Hoffmann, A.A. 1998 Evaluation of the 1998 forest fires in East-Kalimantan (Indonesia) using multitemporal ERS-2 SAR images and NOAA-AVHRR data. Proceedings of The International Conference on Data Management and Modelling Using Remote Sensing and GIS for Tropical Forest Land Inventory, Jakarta, Indonesia, 26-29 October 1998. Also available on hhhtp://smd.mega.net.id/ iffm/n\&r0.htm.

Siswanto, W., Hudiyono and E. Sukrisman 1997. Forest and fire in Indonesia. In: A state-of-art report on some recent forestry policies initiatives and achievements in Indonesia. Ministry of Forestry of the Republic of Indonesia, Jakarta.

SKEPHI 1992 Special report on forest fire. Setiakawan 7(Jan-Jun): 27-59.

Sowerby, J. and Yeager, C.P. 1997 Fire effects on forests, forest wildlife and associated ecosystem processes. Unpublished Report, WWF-IP, Jakarta, Indonesia.

State Ministry of Environment/UNDP 1998 Forest and land fires in Indonesia. Volume 1, Impacts, factors and evaluation, Volume 2, Plan for action for fire disaster management. Jakarta, Indonesia. 
Sunderlin, W. 1998. The Indonesian economic crisis and its impact on the forest sector: a CIFOR perspective. Web site: http://www.cgiar.org/ cifor/.

Suratmo, G. and Coto, Z. 1997 Report of workshop on ITTO-National Forest Fire Strategy. Input paper to the National Workshop

Trenberth, K.E. and Hoar, T.J. 1997 El Niño and climate change. Geophysics Research Letters 24(23): 3057-60.

Trigg, S. 1997 All about EUFREG (European Union Fire Response Group). Input paper to the National Workshop on Repelita VII of Forestry and the $8^{\text {th }}$ Meeting of the Consultative Group on Indonesian Forestry (CGIF), Cisarua, Bogor, 1012 December 1997.

United Nations 1997 Indonesia forest fires September-November 1997. United Nations Disaster Assessment and Coordination (UNDAC) Team Mission Report. Department of Humanitarian Affairs. UN, Geneva, Switzerland.

UN OCHA 1998a Land, bush, and forest fires: UNDAC Mission Report. DPR 213/3 (7-6) INDO 98. Jakarta, Indonesia. 22 pp.

UN OCHA 1998b Indonesia environmental emergency. OCHA Situation Report No. 10. Document OCHA/GVA - 98/0195. Jakarta, Indonesia. $6 \mathrm{pp}$.
Vaas, K.F. 1952 Fisheries in the lake district along the Kapuas river in West Borneo. Proceedings of Indo-Pacific Fisheries Council, Section II: 110. Diocesan Press, Madras, India.

Vayda, A.P., Colfer, C.J.P. and Brotokusumo, M. 1980 Interactions between people and forests in East Kalimantan. Impact of Science on Society 30(3): 179-90.

Vayda, A.P. 1999. Finding causes of the 1997-1998 Indonesian Forest Fires: Problems and Possibilities. A report on preliminary research. Report prepared for WWF-Indonesia.

Wakker, E. 1998 Introducing zero-burning techniques in Indonesia's oil palm plantations. Report prepared for WWF-IP. Published by AIDEnvironment, Jakarta, Indonesia.

WALHI 1998. Legalisasi pembakaran hutan dan penggusuran lahan rakyat. Tanah Air No. 5 Th XVIII/1998.

Wall, D. (1997). Practical lessons learned by the forest fire prevention and control project from the 1997 environmental disaster. Input paper to the National Workshop on Repelita VII of Forestry and the $8^{\text {th }}$ Meeting of the Consultative Group on Indonesian Forestry (CGIF), Cisarua, Bogor, 10-12 December 1997.

WWF 1997 The year the world caught fire. WWF International Discussion Paper by Nigel Dudley. Gland, Switzerland. 

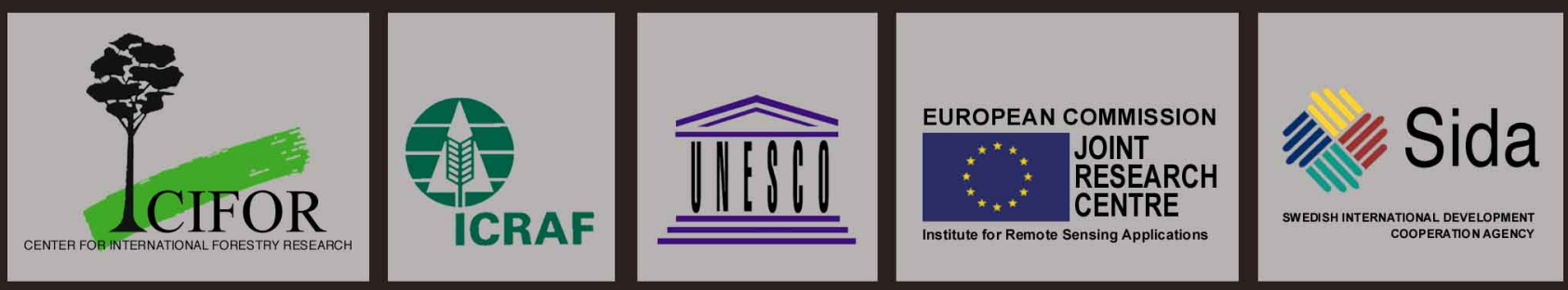